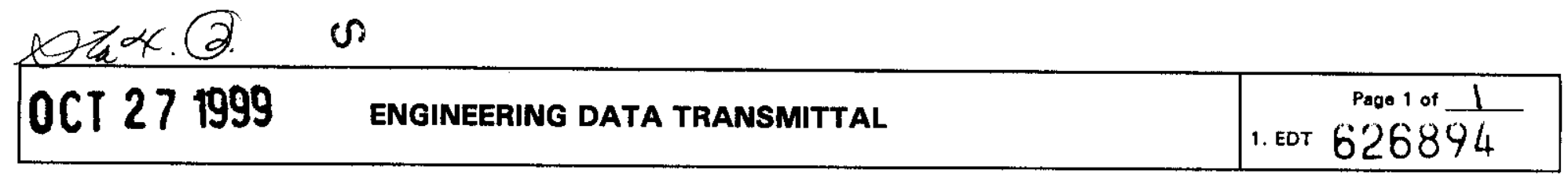

\begin{tabular}{|c|c|c|c|c|c|c|c|c|}
\hline \multicolumn{3}{|c|}{$\begin{array}{l}\text { 2. To: (Receiving Organization) } \\
\text { Distribution }\end{array}$} & \multicolumn{2}{|c|}{$\begin{array}{l}\text { 3. From: (Originating Organization) } \\
\text { Nuclear Safety }\end{array}$} & \multicolumn{4}{|c|}{$\begin{array}{l}\text { 4. Related EDT No.: } \\
\qquad \text { N/A }\end{array}$} \\
\hline \multicolumn{3}{|c|}{$\begin{array}{l}\text { 5. Proj/Prog./Dept/Div.: } \\
\text { Spent Nuclear Fuel Project }\end{array}$} & \multicolumn{2}{|c|}{$\begin{array}{l}\text { 6. Design Authority/ Design Agent/Cog. Engr:. } \\
\text { J. V. Nelson }\end{array}$} & \multicolumn{4}{|c|}{$\begin{array}{r}\text { 7. Purchase Order No.: } \\
\text { N/A }\end{array}$} \\
\hline \multicolumn{5}{|c|}{ 8. Originator Remarks: } & \multicolumn{4}{|c|}{$\begin{array}{r}\text { 9. Equip./Component No.: } \\
\text { N/A }\end{array}$} \\
\hline \multicolumn{5}{|c|}{ For approval and release. } & \multicolumn{4}{|c|}{$\begin{array}{r}\text { 10. System/BIdg./Facility: } \\
\text { K Basins }\end{array}$} \\
\hline \multirow{3}{*}{\multicolumn{3}{|c|}{ 11. Receiver Remarks: }} & \multirow{3}{*}{\multicolumn{2}{|c|}{ Document? [] Yes $[\mathbf{x}]$ No }} & \multicolumn{4}{|c|}{$\begin{array}{r}\text { 12. Major Assm. Dwg. No.: } \\
\text { N/A }\end{array}$} \\
\hline & & & & & \multicolumn{4}{|c|}{$\begin{array}{l}\text { 13. Permit/Permit Application No.: } \\
\text { N/A }\end{array}$} \\
\hline & & & & & \multicolumn{4}{|c|}{$\begin{array}{r}\text { 14. Required Response Date: } \\
\text { N/A } \\
\end{array}$} \\
\hline \multicolumn{2}{|l|}{15.} & \multirow{2}{*}{$\begin{array}{l}\text { DATA } \\
\text { (C) } \\
\text { Sheet } \\
\text { No. }\end{array}$} & TRANSMI & & (F) & (G) & (H) & (l) \\
\hline $\begin{array}{l}(A) \\
\text { Item } \\
\text { No. }\end{array}$ & (B) Documentidraxing No. & & $\begin{array}{l}\text { (D) } \\
\text { Rev. } \\
\text { No. }\end{array}$ & (E) Tithe or Description of Date Trentmitted & $\begin{array}{l}\text { Approval } \\
\text { Desigratior }\end{array}$ & $\begin{array}{c}\text { Reason } \\
\text { for Transs- } \\
\text { mittal }\end{array}$ & $\begin{array}{l}\text { Origi- } \\
\text { nator } \\
\text { Dispo- } \\
\text { sition }\end{array}$ & $\begin{array}{c}\text { Receciver } \\
\text { Disposition }\end{array}$ \\
\hline 1 & SNF-4977 & N/A & 0 & $\begin{array}{l}\text { Integrated Worker Radiation } \\
\text { Dose Assessment for the } \\
\text { K Basins }\end{array}$ & $\mathbf{S}, \mathbf{Q}$ & 1,2 & 1 & 1 \\
\hline & & & & & & & & \\
\hline & & & & & & & & \\
\hline & & & & & & & & \\
\hline & & & & & & & & \\
\hline & & & & & & & & \\
\hline
\end{tabular}

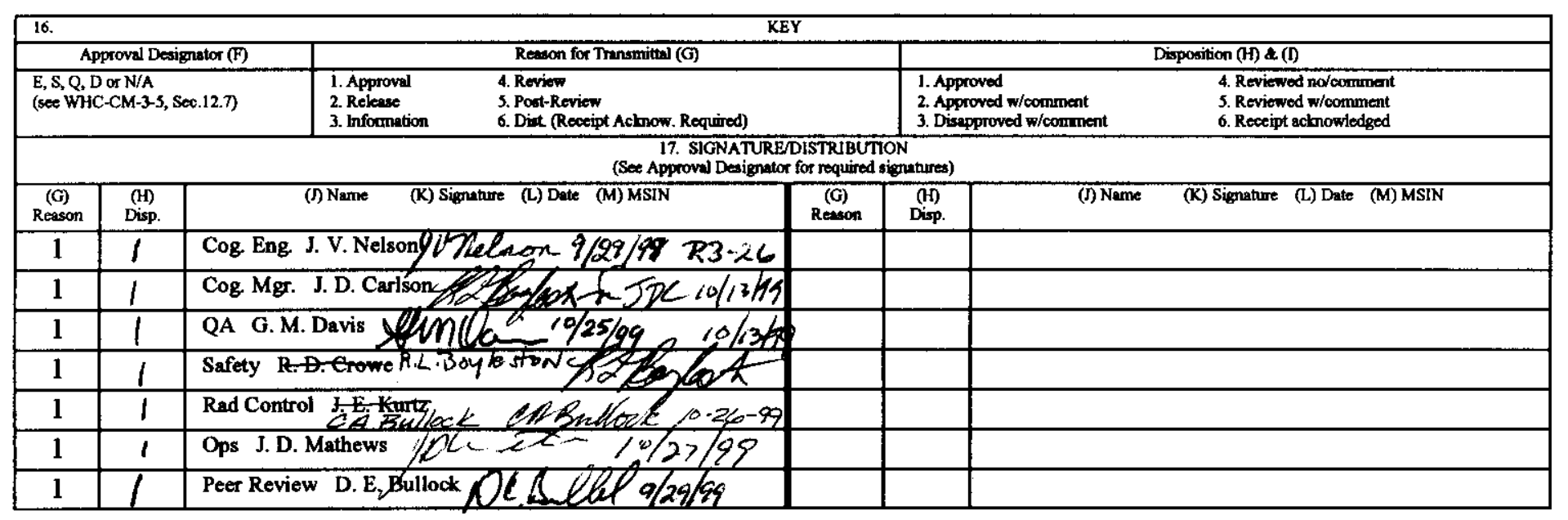

\begin{tabular}{|c|c|c|c|c|c|c|}
\hline $\begin{array}{l}18 . \\
\text { J.v. Nekgon, } \\
\text { Sil Pelaem } \\
\text { Signature of EDT } \\
\text { Orignator }\end{array}$ & $\frac{9 / 29 / 99}{\text { Dato }}$ & $\begin{array}{l}19 . \\
\text { N/A } \\
\text { Authorizod Represententive } \\
\text { for Recaiving Orgenization }\end{array}$ & Date & D.D. Crerkon & $10 / 27 / 99$ & $\begin{array}{l}\text { 21. DOE APPROVAL (if required) } \\
\text { Ctrl. No. } \\
\text { [] Approved } \\
\text { [ ] Approved w/comments } \\
\text { [ ] Disapproved w/comments }\end{array}$ \\
\hline
\end{tabular}

BD-7400-172-2 (05/96) GEF097 


\section{Integrated Worker Radiation Dose Assessment for the K Basins}

\section{J. V. Nelson}

Fluor Daniel Hanford, Inc., Richland, WA 99352

U.S. Department of Energy Contract DE-AC06-96RL13200

EDT: 626894

Org Code: 2F200

B\&R Code: EW31354040
UC: 920

Charge Code: 105414/CB80

Total Pages: 121

Key Words: K Basin, Spent Nuclear Fuel, SNF, Radiation Dose, Fuel Retrieval System, Cask Loading System, Integrated Water Treatment System, FRS, CLS, IWTS

Abstract: This report documents an assessment of the radiation dose workers at the $\mathrm{K}$ Basins are expected to receive in the process of removing spent nuclear fuel from the storage basins. The $\mathrm{K}$ Basins ( $\mathrm{K}$ East and $\mathrm{K}$ West) are located in the Hanford 100K Area.

TRADEMARK DISCLAIMER. Reference herein to any specific commercial product, process, or service by trade name, trademark, manufacturer, or otherwise, does not necessarily constitute or imply its endorsement, recommendation, or favoring by the United States Government or any agency thereof or its contractors or subcontractors.

Printed in the United States of America. To obtain copies of this document, contact: Document Control Services, P.O. Box 950, Mailstop H6-08, Richland WA 99352, Phone (509) 372-2420; Fax (509) 376-4989.
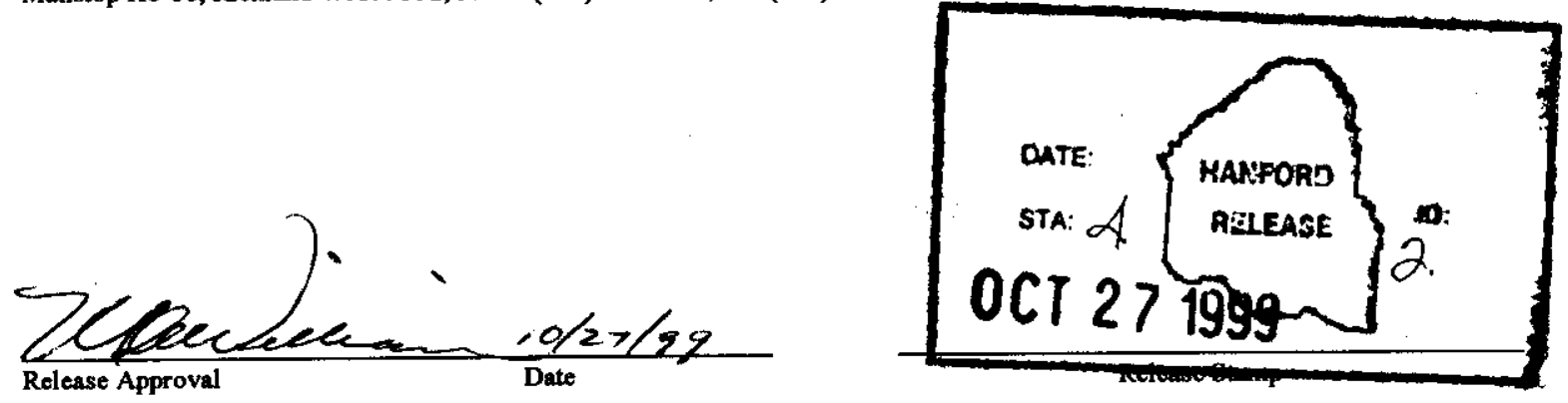

\section{Approved for Public Release}


INTEGRATED WORKER RADIATION DOSE ASSESSMENT FOR THE K BASINS

September 1999 
This page intentionally left blank. 


\section{CONTENTS}

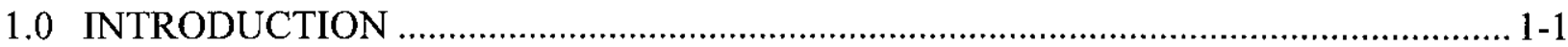

1.1 PURPOSE.

1.2 SCOPE

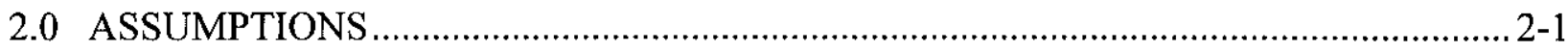

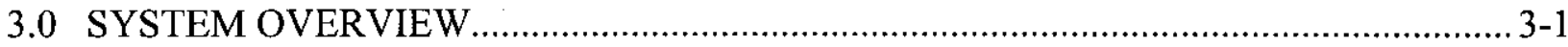

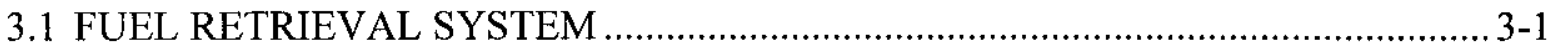

3.1.1 Fuel Retrieval System Equipment Description ................................................ 3-1

3.1.2 Fuel Retrieval System Operations ................................................................ 3-2

3.2 CASK LOADING SYSTEM ………............................................................... 3-8

3.2.1 Cask Loading System Equipment Description................................................ 3-8

3.2.2 Cask Loading System Operations ……........................................................ 3-9

3.3 INTEGRATED WATER TREATMENT SYSTEM .......................................... 3-16

3.3.1 Integrated Water Treatment System Equipment Description............................. 3-16

3.3.2 Integrated Water Treatment System Operations ............................................ 3-16

4.0 DESIGN AND ANALYSIS INPUT ......................................................................... 4-1

4.1 DATA FOR THE FUEL RETRIEVAL SYSTEM ……...................................... 4-1

4.2 DATA FOR THE CASK LOADING SYSTEM.................................................... 4-2

4.3 OPERATIONS DATA FOR THE INTEGRATED WATER TREATMENT

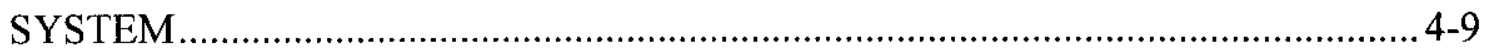

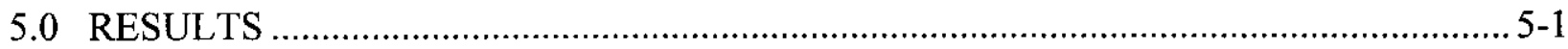

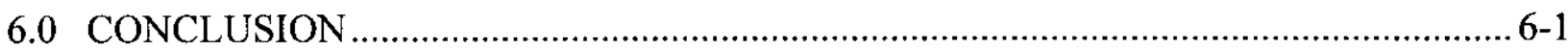

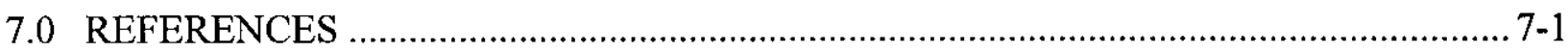


APPENDIX A COMPUTATION OF PERSONNEL DOSES DURING FUEL RETRIEVAL SYSTEM OPERATIONS.

APPENDIX B COMPUTATION OF PERSONNEL DOSES DURING CANISTER LOADING SYSTEM OPERATIONS

APPENDIX C COMPUTATION OF PERSONNEL DOSES DURING INTEGRATED WATER TREATMENT SYSTEM OPERATIONS

APPENDIX D MONTHLY STANDARDIZED DOSE RATE SURVEY FOR K EAST BASIN SURVEY NO. K990483

APPENDIX E MONTHLY STANDARDIZED DOSE RATE SURVEY FOR K WEST BASIN SURVEY NO. L990899.

APPENDIX F SPENT NUCLEAR FUEL PROJECT RADIOLOGICAL SURVEY REPORTS K990552, K990556, K99059, and K990564. F-1

APPENDIX G COMPUTATION OF DOSE RATES IN THE VICINITY OF A LOADED ION EXCHANGE MODULE AT THE K BASINS. G-1

APPENDIX H CHECKLIST FOR TECHNICAL PEER REVIEW $\mathrm{H}-1$ 
SNF-4977 REV 0

\section{LIST OF TABLES}

Table 3-1. Fuel Retrieval System Operations

Table 3-2. Canister Loading System Operational Steps 3-10

Table 4-1. Background Dose Rates at the K Basins

Table 4-2. Manpower Requirements and Personnel Locations Associated with each Operation in the Fuel Retrieval Process.

Table 4-3. Dose Rates from a Filled Cask-Multi-Canister Overpack that is Exposed 4-5

Table 4-4. Manpower Requirements and Personnel Locations Associated with each Cask Loading System Operation

Table 4-5. Dose Rates in Vicinity of a Loaded Integrated Water Treatment System Ion Exchange Module

Table 4-6. Manpower and Personnel Location Requirements for Integrated Water Treatment System Operations and Maintenance

Table 4-7. Manpower Estimates and Dose Rates for an Integrated Water Treatment System Ion Exchange Module Changeout.

Table 5-1. Personnel Exposures from Fuel Retrieval Operations....................................... 5-1

Table 5-2. Personnel Exposures from Canister Loading System Operations .......................... 5-2

Table 5-3. Personnel Exposures from K West Basin Integrated Water Treatment System Operations 


\section{LIST OF TERMS}

$\begin{array}{ll}\text { ALARA } & \text { as low as reasonably achievable } \\ \text { CLS } & \text { cask loading system } \\ \text { FRS } & \text { fuel retrieval system } \\ \text { HPT } & \text { health physics technician } \\ \text { IPSS } & \text { immersion pail support structure } \\ \text { IWTS } & \text { integrated water treatment system } \\ \text { IXM } & \text { ion exchange module } \\ \text { MCO } & \text { multi-canister overpack } \\ \text { MLS } & \text { multi-canister overpack loading system } \\ \text { PCM } & \text { primary clean machine } \\ \text { PIC } & \text { person-in-charge } \\ \text { SNF } & \text { spent nuclear fuel }\end{array}$




\section{INTEGRATED WORKER RADIATION DOSE ASSESSMENT FOR THE K BASINS}

\subsection{INTRODUCTION}

The goal of the Spent Nuclear Fuel (SNF) Project is to remove all SNF from the K Basins in the Hanford $100 \mathrm{~K}$ Area and put it in interim dry storage in the Canister Storage Building located in the 200 East Area. Removal of the SNF from the K Basins entails loading fuel elements and fuel scrap into specially designed baskets, which are stacked in water-filled multicanister overpacks (MCOs). Systems designed to remove spent fuel and fuel scrap from the $\mathrm{K}$ Basins include the fuel retrieval system (FRS) and the cask loading system (CLS). Another new system at the K Basins, the integrated water treatment system (IWTS), is designed to remove particulate and dissolved materials generated during FRS operations.

\section{$1.1 \quad$ PURPOSE}

The purpose of this report is to document an assessment of radiation doses workers are expected to receive while carrying out routine activities supporting FRS, CLS, and IWTS operations and maintenance. Personnel doses were evaluated using current system designs, process flow information, operation sequences, and measured or computed dose rates.

\subsection{SCOPE}

The analysis is limited to normal operations and planned maintenance activities. Personnel doses incurred during off-normal operations and unexpected repair work are not assessed in this report. Doses incurred during installation and decommissioning of $\mathrm{K}$ Basin systems are not included. The excluded activities are or will be covered in system ALARA (as low as reasonably achievable) reports. 
SNF-4977 REV 0

This page intentionally left blank. 


\subsection{ASSUMPTIONS}

The personnel dose associated with each operational task was obtained by adding the doses received by each individual involved in the task. A worker's dose is the product of the time he spends in a radiation zone and the average dose rate in the zone. The annual dose burden is computed by summing the product of the dose associated with each operational task and the number of times the task is expected to be performed per year.

Activities at the $\mathrm{K}$ Basins were identified and the details of each activity were obtained from the following sources:

- HNF-2032, SNF Fuel Retrieval Subproject Safety Assessment Document

- HNF-2456, Cask Loadout System Safety Analysis Document

- IWTS ALARA report (Kensicki 1997)

- $\quad$ HNF-SD-SNF-SAD-002, K West Basin Integrated Water Treatment System Subproject Safety Analysis Document

- Ion Exchange Module Replacement Spreadsheet (Bullock 1999b).

In addition, the FRS and CLS activities and estimates of the manpower required to complete each activity were based on an assessment made by K Basin personnel in 1996 and updated in 1999 (Bullock 1999a).

Background dose rates at the $\mathrm{K}$ Basins are based on recent measurements by health physics technicians (HPTs). These dose rates should be representative of current conditions at the $\mathrm{K}$ Basins. However, ongoing efforts to reduce radioactive contamination at the $\mathrm{K}$ East Basin could result in lower dose rates at the time of fuel retrieval and removal operations. Dose rates from a loaded MCO were based on calculations reported in HNF-SD-SNF-CN-026, MCO Shield Plug Dose Rate Analysis. Dose rates related to IWTS activities were taken from the recent dose rate measurements at the $\mathrm{K}$ Basins (see Appendices D and $\mathrm{E}$ ) and the assessment of the manpower required to remove and replace an IWTS ion exchange column (Bullock 1999b).

In computing annual doses, it was assumed that a total of $200 \mathrm{MCOs}$ will be filled and shipped from the K Basins per year (100 from each basin). MCOs will contain either five Mark IV baskets or six Mark IA baskets, with an average of 5.3 baskets used in this analysis. Mark IV baskets can hold 54 fuel assemblies, while Mark IA fuel baskets can hold 48 fuel assemblies. SNF at the K Basins is stored in double-barreled canisters that contain seven assemblies per barrel. Thus, an MCO containing Mark IV fuel can hold up to the equivalent contents of 19.3 fuel canisters, while an MCO containing Mark IA fuel can hold up to the equivalent of 20.6 fuel canisters. However, MCOs may not be filled with baskets containing intact fuel, so an average of 19 canisters per MCO was assumed in this analysis.

Computation of total project doses was based on the estimate that 440 MCOs will be needed to package all the SNF in both basins (220 MCOs from each basin). Based on 100 


\section{SNF-4977 REV 0}

MCOs loaded per year per basin, the fuel removal project will be completed in 2.2 years. Sludge removal is expected to extend the need for the IWTS, but 2.2 years was assumed to be the operational lifetime of the IWTS as well as the FRS and CLS. It also was assumed that there are 250 working days per year, three shifts per day with operations taking place an average of 7.3 hours per shift (22 hours per day). 


\subsection{SYSTEM OVERVIEW}

The K Basin safety analysis report (WHC-SD-WM-SAR-062) describes the K Basins storage facilities, which consist of two fuel storage basins (K East and $\mathrm{K}$ West) and related support facilities. Major systems being added to the $\mathrm{K}$ Basins to accomplish the goal of removing the SNF stored on the floor of the basin pools include the FRS, the CLS, and the IWTS, which are described in the following sections.

\subsection{FUEL RETRIEVAL SYSTEM}

\subsubsection{Fuel Retrieval System Equipment Description}

The FRS being installed in the K East and K West Basins consists basically of operator aids (tools) designed to support retrieval, cleaning, inspecting, and repackaging of fuel into $\mathrm{MCO}$ baskets, then queuing these baskets for loading into the MCO. Major equipment added to the $\mathrm{K}$ Basin facility as part of the FRS includes:

- Decapping equipment and gas exhaust system to allow controlled removal of canister caps ( $\mathrm{K}$ West Basin only)

- $\quad$ Primary clean machine (PCM) to clean fuel and control wash water

- Stuck fuel removal equipment to free fuel stuck in canisters after washing

- $\quad$ Process table to allow sorting, inspecting, and loading of fuel into the MCO baskets and to hold empty MCO baskets

- $\quad \mathrm{MCO}$ basket queue to stage the loaded MCO baskets

- Manipulator system, which includes cameras, lighting, and an equipment operations center for viewing and control of fuel handling operations, to allow sorting, inspecting, and loading of fuel into the MCO baskets.

Changes to the existing fuel handling system include:

- Upgrading the capacity of selected monorails and flexible transfer crane rails to safely handle the increased loads of the MCO baskets

- Installing new flexible transfer crane with drive system to ease movement of loaded MCO baskets

- Installing monorail extension south of the perimeter monorail to facilitate bringing loads into the basin

- Installing new hoist with drive system for movement of loaded MCO baskets 
- Installing variable-speed hoists in the K East Basin to control lifting of canisters to minimize sludge plume

- Installing telescoping stiffbacks for moving canisters, PCM wash baskets, and debris bins

- Installing MCO basket stiffback grapple and empty MCO basket grapple to allow moving of $\mathrm{MCO}$ baskets

- Modifying the basin grating to accommodate the new FRS equipment and operations.

\subsubsection{Fuel Retrieval System Operations}

The FRS operations are described briefly in Sections 3.1.2.1 through 3.1.2.6. The descriptions were extracted from HNF-2032. The steps necessary to retrieve fuel canisters, process their contents, and load MCO baskets are summarized in Table 3-1.

3.1.2.1 Canister Staging. Spent fuel elements and scrap in the K Basins are normally stored in canisters that have been placed in fuel racks on the basin floor. Intact canisters are transported to the staging area north of the PCM using the basin monorail system. Fuel in damaged canisters (e.g., bottom corroded) may be transferred to new canisters before transit. Damaged canisters are expected only in the K East Basin. SNF on the basin floor may also be retrieved for processing using manual tools. In the K East Basin, variable-speed hoists are used to minimize sludge plume effects resulting from rapid canister lifting.

Canisters are moved by lowering the telescoping stiffback into position, engaging the hook on the canister trunnion, and raising the hoist to lift the telescoping stiffback and the canister. A canister is moved using the drive tractor if the telescoping stiffback is equipped with one or by manually pushing the trolley, hoist, and telescoping stiffback along the rail. The trolley can be moved onto the flexible transfer crane to enable movement between monorails. Once the load is in position, the hoist is lowered to set the canister down.

3.1.2.2 Canister Decapping ( $K$ West only). Canisters of fuel in the $K$ West Basin are stored capped. As a result, contaminated water, sludge, and gases have accumulated in the canisters. The canisters must be opened to retrieve the fuel. To maintain basin water quality, canisters are decapped in an enclosure that minimizes release of the canister water and gas during decapping. Water is continuously pumped from the enclosure through a strainer to the IWTS. 
Table 3-1. Fuel Retrieval System Operations. (2 sheets)

\begin{tabular}{|c|c|}
\hline Step* & Description \\
\hline 1.0 & Get canister and move to cleaning station staging area \\
\hline 1.01 & Get next canister location from chief operator \\
\hline 1.02 & Move underwater light to location of next canister \\
\hline 1.03 & Locate canister \\
\hline 1.04 & Verify canister location with chief operator \\
\hline 1.05 & Move offset hook to canister location (if needed) \\
\hline 1.06 & Identify receiving in-line canister location (if needed) \\
\hline 1.07 & Pick up canister with offset hook, use pick and pause (if needed) \\
\hline 1.08 & Move canister to in-line row (if needed) \\
\hline 1.09 & Move offset hook out of the way (if needed) \\
\hline 1.10 & Move basin hoist and telescoping stiffback to in-line canister location \\
\hline 1.11 & Pick up canister using basin hoist and telescoping stiffback; use pick and pause \\
\hline 1.12 & Move basin hoist with canister north on rail to north wall $(30 \mathrm{ft} / \mathrm{min})$ \\
\hline 1.13 & Unlock rails as needed \\
\hline 1.14 & Transfer basin hoist with canister to perimeter trolley \\
\hline 1.15 & Move trolley and hoist with canister to cleaning station staging area $(30 \mathrm{ft} / \mathrm{min})$ \\
\hline 1.16 & Unlock rails as needed \\
\hline 1.17 & Transfer hoist with canister to rail at cleaning station staging area \\
\hline 1.18 & Set canister down into an empty cubicle in cleaning station staging area \\
\hline 1.19 & Sign accountability form \\
\hline 1.20 & $\begin{array}{l}\text { Pick up previously emptied canister with basin hoist and telescoping stiffback and take empty } \\
\text { canister to cleaning station staging area }\end{array}$ \\
\hline 1.21 & Take hoist to next canister location to pick up another canister \\
\hline 1.22 & Repeat from Step 1.01 until cleaning station staging area is full; then go to Step 2.01 \\
\hline 2.00 & Load washer, wash fuel, dump fuel onto inspection table, and load fuel basket \\
\hline 2.01 & Pick up canister in staging area using cleaning station hoist and telescoping stiffback \\
\hline 2.02 & Put canister in decapper; degas, delid, and dewater canister (K West only) \\
\hline 2.03 & Put canister lids in debris basket (K West only) \\
\hline 2.04 & Pick up canister out of decapper (K West only) \\
\hline 2.05 & Open PCM lid and put canister in the PCM \\
\hline 2.06 & Close PCM lid and start PCM \\
\hline 2.07 & When PCM stops, open lid and remove canister with cleaning station hoist and telescoping stiffback \\
\hline 2.08 & Dump fuel onto inspection table \\
\hline 2.09 & Verify canister is empty; if so, set canister down in empty cubicle in washing station staging area \\
\hline 2.10 & If canister is not empty, remove stuck fuel in canister and put fuel in PCM \\
\hline 2.11 & Close PCM lid and start washing \\
\hline 2.12 & Separate fuel elements \\
\hline
\end{tabular}


Table 3-1. Fuel Retrieval System Operations. (2 sheets)

\begin{tabular}{|c|c|}
\hline Step* & Description \\
\hline 2.13 & Inspect elements \\
\hline 2.14 & Rewash fuel if needed \\
\hline 2.15 & Load fuel into fuel basket that has been previously staged on the inspection table \\
\hline 2.16 & $\begin{array}{l}\text { Repeat from Step } 2.01 \text { until there are no more full canisters in the cleaning station staging area or } \\
\text { until an MCO basket is full. If a basket is full, go to Step } 3.01 \text {. If there are no more full canisters in } \\
\text { the cleaning station staging area, go to step } 1.01\end{array}$ \\
\hline 3.00 & Take full MCO basket to staging area and bring in new, empty basket \\
\hline 3.01 & Pick up full MCO basket with basket hoist and stiffback grapple \\
\hline 3.02 & Weigh the full MCO basket and record weight \\
\hline 3.03 & Videotape the full MCO basket \\
\hline 3.04 & Move the full MCO basket south on rail using the motorized hoist \\
\hline 3.05 & $\begin{array}{l}\text { Transfer motorized basket hoist with the full MCO basket to motorized trolley. Take the full MCO } \\
\text { basket to the MCO basket queue and set the basket down using the motorized trolley }\end{array}$ \\
\hline 3.06 & Pick up new, empty MCO basket; take to inspection table; and set empty basket on inspection table \\
\hline 3.07 & Record new MCO basket number \\
\hline 3.08 & Go to Step 2.16 \\
\hline
\end{tabular}

*Step numbers are not official designations. They are included in this report as a convenient means of referring to individual steps.

$\mathrm{MCO}=$ multi-canister overpack.

$\mathrm{PCM}=$ primary clean machine.

The K West Basin contains two types of canisters: Mark I and Mark II. The Mark I canisters can be made of aluminum or stainless steel. The Mark I canisters have a loose gas trap connected to the canister lid by metal tubing. They can be sealed with a compression-type cover. The Mark II canisters are made of stainless steel, have an integral gas trap attached to the canister barrels, and can be sealed. The K West Basin contains approximately 800 aluminum and 1,000 stainless steel Mark I canisters and 2,000 Mark II canisters.

The decapping process consists of the following steps:

1. A canister is retrieved from the staging area with the telescoping stiffback. For a Mark I canister, the gas trap line is cut with a long-handled tool to remove gas trap before the canister is placed in the canister storage area. The gas traps are staged for transport to debris removal.

2. The decapper enclosure clamshell top is opened, the canister is placed into the enclosure, the telescoping stiffback is removed, and the clamshell top is closed.

3. Gases are released by opening the valve or pressurizing the cap, as appropriate.

4. The canister cap is removed from the canister. 
5. The canister is flushed with water.

6. The canister enclosure is opened, and the cap is removed from the enclosure. The cap is placed in a debris container.

7. The telescoping stiffback is attached to the canister, and it is removed from the enclosure.

8. The decapping equipment is inspected for sludge accumulation and cleaned if necessary.

The IWTS and the exhaust gas system are in service during decapping activities. Not all the canister gases are released in the decapping equipment. Some gas may be released through the canister vent system as the canister is moved from the racks to the decapping equipment. Other losses may occur as the gas traps are cut. Some gas may remain in the Mark I gas trap after it is removed from the canister.

Canister caps, gas traps, and other debris are transferred to the debris staging area, as necessary, using the telescoping stiffback. Material accumulated in the strainer is emptied onto the process table, as necessary, using the telescoping stiffback.

3.1.2.3 Primary Cleaning. The primary cleaning process involves rotating a canister of fuel in an enclosure while high-pressure water is sprayed into the canister. As a result, the fuel slides from one end of the canister to the other, corrosion particles are knocked from the $\mathrm{SNF}$, and fuel stuck to the canister is loosened.

The main suction pump operates during all PCM operations. With the PCM lid open, a canister is loaded vertically into the bottom half of the wash basket using the telescoping stiffback. The top half of the wash basket is put in place, and the PCM lid is closed. The main drive and high-pressure pump are started, and the fuel and canister are rotated in the wash basket for approximately $20 \mathrm{~min}$. When the wash cycle is complete, the high-pressure pump is stopped and the PCM is flushed for approximately $10 \mathrm{~min}$ to clear residual sludge. The PCM is stopped, and the lid is opened. The fuel canister is removed and transported to the process table with the telescoping stiffback.

During the initial operation of the PCM, validation testing will be performed to establish the operating parameters necessary to ensure that the SNF is adequately cleaned. During this validation process, the fuel canister and the wash basket will be removed with the telescoping stiffback and moved to the tipping station of the process table to dump the fuel on the table surface. The fuel will then be inspected to demonstrate that it meets the cleanliness criteria.

The PCM is inspected for sludge and scrap accumulation and cleaned as required. The PCM strainer is cleaned as required. The strainer is moved by lowering the stiffback into position, engaging the hook on the strainer trunnion, then raising the hoist to lift the stiffback and the strainer. Wash baskets are raised in a similar fashion using only the telescoping stiffback, which has a spreader bar above the hook for lifting the wash baskets. 
3.1.2.4 Stuck Fuel Removal. The cleaning process is expected to loosen SNF in the canister. Occasionally some fuel may remain stuck to the canister. Canisters with stuck fuel are transported and loaded into the stuck fuel removal equipment with the telescoping stiffback. The canister is secured in place, and the saw is placed on one of the two guideposts. Next, the saw is started and a hand crank is used to feed it down into the canister, slicing the barrel. After the cut has been made to the desired length, the saw can be repositioned to make a cut on the other barrel. If two cuts per barrel are required, the canister can be rotated 180 degrees and the cutting process repeated. When the cuts are complete, the canister barrels can be spread apart using a hydraulically operated spreader to loosen the fuel assemblies, if necessary.

The fuel is cleaned again after the cutting operation to remove any loosened sludge and cutting particles. Fuel assemblies can be placed in a second canister held in the stuck fuel equipment for movement to the PCM. Alternatively, slit canisters can be moved directly to the PCM without removing the fuel elements.

Waste particles generated by the sawing operation fall into the canister or onto the platform under the canister. The stuck fuel equipment is cleaned using a suction wand connected to the IWTS, as necessary, to prevent a significant accumulation of fuel scrap, sludge, or machine chips.

\subsubsection{Spent Nuclear Fuel Sorting, Inspection, and Multi-Canister Overpack} Basket Loading. After cleaning in the PCM is complete, the SNF is transported to the process table. If the fuel is in good condition, the canister can be moved to the vertical unloading station in the process table. The SNF then can be removed from the canister with the manipulator. If the SNF is not in good condition, the wash basket containing the fuel is moved to the tipper station on the process table using the telescoping stiffback. The SNF is dumped onto the process table sort area by rotating the wash basket in the tipper.

If SNF inspection is required, the fuel assembly is moved to the fuel element disassembly station to separate the inner element from the outer element, if necessary. The fuel elements are inspected, as needed, to support validation or to determine cleanliness.

The manipulators are used to sort and inspect fuel, sort debris from fuel, and load fuel into the MCO baskets. Normally, operations on the process table are completed using two manipulator assemblies running along the same set of bridge rails. Each manipulator is used to perform a predefined set of tasks. The first unit picks up fuel from the sort table and moves it through disassembly, inspection, and secondary cleaning as required. The fuel is placed on the ramp of the table. The second manipulator is dedicated to MCO basket loading. Each manipulator can independently cover the entire process table length.

Fuel elements (whole or partial elements longer than $3 \mathrm{in}$.) separated from fuel scrap are placed on the ramp on the middle section of the process table. Fuel scrap between $1 \mathrm{in}$. and 3 in. long, plus other elements that cannot be loaded into the assembly basket because of bloomed ends are loaded into an MCO scrap basket on the north process table. "Fine" fuel scrap between $0.25 \mathrm{in}$. and $1 \mathrm{in}$. long is placed only in the center "fines" section of the MCO scrap basket. This allows the amount of fine scrap loaded in the MCO to be controlled to support MCO loading 
safety requirements defined in HNF-SD-SNF-OCD-001, Spent Nuclear Fuel Project Product Specification.

Debris is nonreactor-origin material separated from the fissile material. Material that has been irradiated in the reactor as part of the fuel is not considered debris. Debris collected from the processing table is loaded into canisters placed in the debris bin in the process table. A canister in the debris bin sits above the table surface to prevent fuel from accidentally falling into the canister. When the canister is filled with debris, the canister and debris are transferred to a debris staging area using the telescoping stiffback and the monorail system. Procedural controls and inspections of the fuel sorting activities reasonably ensure that fuel pieces do not inadvertently get into the debris. The debris-removal activities need to ensure that the delivered debris does not contain any tramp SNF before it is removed from the basin.

Fuel elements are cleaned in the secondary cleaning station, as needed, using longhandled tools. Fuel elements are placed in the "upending" jigs by the operator using the manipulator jaws. The fuel elements are picked up from the jig with the manipulator "expansion tool" inserted into the center hole of the element. The fuel elements can then be loaded into the assembly basket. Fuel elements that do not fit in the jig because of damaged ends are placed in an MCO scrap basket in the south process table MCO scrap basket container.

Pieces of elements longer than 3 in. may be placed in the MCO fuel assembly basket located at the south end of the process table. Typically, an outer element is placed in the basket first, and an inner element is placed inside the outer element. This sequence may be adjusted case by case because some of the fuel elements are broken and will have to be made up by stacking pieces. Pieces shorter than 3 in. and damaged fuel elements that do not fit into the MCO fuel basket are loaded into an MCO scrap basket in the south end of the process table. The broken fuel jig may be used, as needed, to measure fuel element pieces before loading. Following loading of some scrap elements, the MCO scrap basket may be transferred to the MCO scrap basket container in the north sort area where additional scrap and fine scrap may be loaded.

3.1.2.6 Multi-Canister Overpack Basket Handling. When a loaded MCO basket needs to be moved, a 4,000-lb hoist with the MCO stiffback grapple attached is positioned over the MCO basket. The hoist lowers the stiffback grapple to insert the end of the grapple into the center pipe of the MCO basket. The grapple locking pin is disengaged, and the operating lever is moved to the "engaged" position to engage the ball detent grapple with the fit in the MCO basket center tube. The locking pin is re-engaged to lock the operating lever in the engaged position. The hoist is raised slightly to lift the grapple and the attached MCO basket to ensure that the basket is free. The MCO basket is weighed using the built-in load cell before it is completely lifted from the storage position in the process table. This ensures that basket mass limits for criticality control are not exceeded. After the MCO basket mass has been confirmed to be within limits, the basket is lifted clear of the supporting structure.

Once lifted, the MCO basket is transported along the monorail and onto the flexible transfer crane. When the basket is loaded onto the flexible transfer crane, the flexible transfer crane can move the MCO stiffback grapple and attached basket to the MCO basket queue. Once in position, the MCO basket is lowered into the storage space until it rests on the bottom plate. 
The MCO basket grapple is then detached and removed. Similar steps are used to move the $\mathrm{MCO}$ basket between positions in the process table and to remove a loaded $\mathrm{MCO}$ basket from the $\mathrm{MCO}$ basket queue and place it onto the MCO loading equipment shuttle.

Empty MCO baskets are brought into the building and staged in corridor 10. The empty MCO baskets are transported into the basin area on a cart or pallet jack and placed under the monorail extension south of the basin (monorail 27). The empty MCO basket grapple is attached to the basket, and the empty MCO basket is lifted from the cart with the hoist. Once lifted, the trolley, hoist, empty MCO basket grapple, and empty MCO basket are pushed over the basin on the monorail and onto the flexible transfer crane. The hoist lowers the assembly and sets the empty MCO basket on the existing fuel racks or empty MCO basket tables. The empty basket grapple is disengaged from the basket and removed from the water. When needed, the empty MCO basket is moved into position on the process table using the MCO stiffback grapple.

3.1.2.7 Fuel Retrieval System Equipment Maintenance. No routine maintenance is expected to be required for any of the FRS equipment listed in Section 3.1.1.

\subsection{CASK LOADING SYSTEM}

\subsubsection{Cask Loading System Equipment Description} include:

Major pieces of equipment added to the $\mathrm{K}$ East and $\mathrm{K}$ West Basins as part of the CLS

- Immersion pail used to minimize radioactive contamination of the outside of the cask from the basin water when the cask-MCO is submerged for loading

- Immersion pail support structure (IPSS) - a vertical steel frame installed in the south loadout pit to support and guide the immersion pail

- $\quad$ MCO loading system (MLS) shuttle - consisting of a cart and supporting frame located in the transfer channel used to move loaded MCO baskets from a position over the FRS MCO basket queue to a position next to the IPSS

- MLS gantry and support structure - a single-axis bridge lifting device that spans the transfer channel and travels east-west from a position next to the IPSS to a position directly over the cask-MCO used for loading MCO baskets into the MCO.

The CLS interfaces with the following equipment:

- $\quad$ Fuel Retrieval Subproject MCO basket stiffback grapple

- $\quad \mathrm{MCO}$ and MCO baskets

- IWTS

- $\mathrm{K}$ Basins transfer bay crane 
- Cask transport system.

Changes made at the $\mathrm{K}$ Basins for the CLS include:

- Addition of a windbreak structure to the transfer bay entrance

- Modification of the mezzanine structure to accommodate the gantry

- Modification of the basin grating to accommodate the new CLS equipment and operations

- Addition of tie-ins to electrical, water, and compressed air systems.

\subsubsection{Cask Loading System Operations}

CLS operations are described in Sections 3.2.2.1 through 3.2.2.4, and maintenance activities are described briefly in Section 3.2.2.5. The descriptions were extracted from HNF-2456. The steps necessary to move MCO baskets from the FRS basket queue to a loadout pit and load the baskets into a cask-MCO are summarized in Table 3-2.

\subsubsection{Multi-Canister Overpack/Cask Receipt and Loading Preparation.} Preparation for loading an MCO begins when a transport carrying an empty MCO from the Canister Storage Building in a shipping cask arrives outside the windbreak structure at the basin transfer bay. The transfer bay roll-up door (No. 157) is opened, and the tractor positions the trailer carrying the cask-MCO in the transfer bay. Exhaust trunks are connected to the tractor as required by Industrial Safety.

Once the trailer is positioned in the transfer bay, the trailer jacks are lowered and the trailer is disconnected from the tractor. The exhaust trunks are removed, and the tractor is moved outside the transfer bay to an area clear of the windbreak. The trailer is connected to the building compressed air system. The trailer is leveled using the landing gear. The transfer bay door is lowered. A radiation survey of the cask-MCO is completed to ensure that contamination levels are within acceptable limits.

The four quick-release locking pins from the cask hold-down device are removed, freeing the cask for vertical movement. The hooks for the transfer bay crane are aligned and engaged with the cask-lifting trunnions; the crane hoist applies tension to the wire ropes and cask load. The cask clamp is swung open, freeing the cask for lateral movement. The transfer bay crane is then used to lift the cask-MCO clear of the trailer and tie-down device and move it from the transport trailer to the area above the south loadout pit. 
Table 3-2. Canister Loading System Operational Steps. (2 sheets)

\begin{tabular}{|c|c|}
\hline Step* & Description \\
\hline 1.00 & Cask-MCO receipt and loading preparations \\
\hline 1.01 & Prepare receiving area \\
\hline 1.02 & Back trailer in \\
\hline 1.03 & Prepare to separate trailer \\
\hline 1.04 & Separate trailer and remove tractor \\
\hline 1.05 & Level trailer and close roll-up door \\
\hline 1.06 & Perform a radiation survey of the cask \\
\hline 1.07 & Release cask tie-downs \\
\hline 1.08 & Attach 32-ton crane to cask \\
\hline 1.09 & Disconnect clamshell \\
\hline 1.10 & Lift cask and move to south loadout pit \\
\hline 1.11 & Inspect IP \\
\hline 1.12 & Put cask into IP. \\
\hline 1.13 & Retrieve torque tool, loosen lid bolts, remove tool, and disconnect hoist \\
\hline 1.14 & Attach lid slings \\
\hline 1.15 & Remove cask lid and store \\
\hline 1.16 & Disconnect 32-ton crane \\
\hline 1.17 & Connect to IP lid, install, and test \\
\hline 1.18 & Fill IP with water \\
\hline 1.19 & Remove locking ring with locking ring tool and store \\
\hline 1.20 & Fill MCO with water, install basket guide \\
\hline 1.21 & Connect 32-ton crane to IP with slings \\
\hline 1.22 & Release lock pins \\
\hline 1.23 & Lower IP system to bottom \\
\hline 1.24 & Remove lift beam, slings, and IP from 32-ton crane and store \\
\hline 2.00 & Load MCO with fuel or scrap basket. Repeat until MCO is full. \\
\hline 2.01 & $\begin{array}{l}\text { Move MCO basket from FRS basket queue to MLS shuttle with 2-ton } \\
\text { flexible transfer crane and MCO basket stiffback grapple }\end{array}$ \\
\hline 2.02 & Verify fuel does not extend above the top of MCO basket \\
\hline 2.03 & Move MCO basket through transfer channel with the shuttle \\
\hline 2.04 & Lock gantry mast and grapple assembly to $\mathrm{MCO}$ basket \\
\hline 2.05 & Lift MCO basket and verify that its weight is within acceptable range \\
\hline 2.06 & Return shuttle to a position next to basket queue \\
\hline 2.07 & Lower MCO basket into the $\mathrm{MCO}$ \\
\hline 2.08 & $\begin{array}{l}\text { Open grapple to release basket, verify release, and return gantry mast and } \\
\text { grapple assembly to the shuttle unload position }\end{array}$ \\
\hline 2.09 & Repeat from Step 2.01 until MCO is full \\
\hline
\end{tabular}


Table 3-2. Canister Loading System Operational Steps. (2 sheets)

\begin{tabular}{|c|c|}
\hline Step* & Description \\
\hline 3.00 & Shield plug installation \\
\hline 3.01 & Prepare MCO shield plug \\
\hline 3.02 & Remove MCO basket guide and clean plug sealing area \\
\hline 3.03 & Install MCO shield plug \\
\hline 3.04 & Remove plug lift rig \\
\hline 4.00 & Cask-MCO loadout and preparation for transfer \\
\hline 4.01 & Reconnect IP lift beam and slings \\
\hline 4.02 & Raise IP to pool surface \\
\hline 4.03 & Rinse MCO top and IP lid \\
\hline 4.04 & Raise IP and pin in upper position \\
\hline 4.05 & Remove lift slings and beam and store \\
\hline 4.06 & Decontaminate MCO shield plug and IP lid \\
\hline 4.07 & Clean threads and install locking ring \\
\hline 4.08 & Deflate IP lid seals and remove bolts \\
\hline 4.09 & Remove IP lid \\
\hline 4.10 & Adjust cask water level with suction tool \\
\hline 4.11 & Install cask lid and torque bolts \\
\hline 4.12 & Open cask port cover and adjust gas composition \\
\hline 4.13 & Attach crane to cask and raise from IP \\
\hline 4.14 & Dry, survey, and smear cask surface \\
\hline 4.15 & Move cask and tie-down on trailer \\
\hline 4.16 & Connect tractor to trailer \\
\hline 4.17 & Perform final radiation survey \\
\hline 4.18 & Release cask for transfer to CVDF \\
\hline 4.19 & Drive tractor/trailer away \\
\hline
\end{tabular}

Step numbers are not official designations. They are included in this report only as a convenient way of referring to individual steps.

CVDF $=$ Cold Vacuum Drying Facility.

$\mathrm{IP}=$ immersion pail.

$\mathrm{MCO}=$ multi-canister overpack.

MLS $=$ MCO loadout system . 
Two other activities occur in parallel with cask receipt at the $\mathrm{K}$ Basins. The first is inspecting the immersion pail lid and the immersion pail in preparation for transferring the caskMCO from the trailer into the immersion pail. The seal surface of the pail lid is inspected for damage that might affect the inflatable seal. The inflatable seal is inspected for wear (including cracking and feathering) and, if necessary, replaced. Installation of the pail lid fasteners in their captive position is visually verified. The lift sling is installed, with one sling leg on each of the three pail lid lift lugs. The pail lid is ready for installation on the pail. The second activity begins by inspecting the immersion pail for proper position in the IPSS and correct pail lock position. The inside of the pail is visually inspected to ensure that it is free of foreign material or debris. The pail-sealing surface is inspected for nicks, scars, or gouges that might affect the inflatable seal. The immersion pail water level then is checked to verify that water in the pail has reached the correct level. Demineralized (i.e., fresh makeup) water is added as required. At this point, the pail is ready to receive the cask-MCO.

Before lowering the cask-MCO into the immersion pail, the cask position over the loadout pit is verified relative to the immersion pail. The transfer bay crane lowers the caskMCO into the immersion pail until the cask rests on the bottom. The transfer bay crane hooks are disconnected and removed from the cask. The auxiliary hoist is used to install a cask-torquing tool, and the cask lid bolts are loosened. When the lid bolts are verified to have disengaged from the cask, the torquing tool is removed and stored. The transfer bay crane hooks are connected to the cask lid, and the cask lid is removed. The cask lid is positioned on the cask lid storage tool where the o-ring is visually inspected for wear.

The lift sling is connected to the immersion pail lid. The immersion pail lid is lowered into place using guide pins to ensure correct positioning. The four pail lid retention fasteners are engaged, and the immersion pail lid seals are inflated to $45 \mathrm{lb} / \mathrm{in}^{2}$ gauge maximum using the building compressed air. The annular region of the immersion pail and cask is filled with demineralized water by the water supply for the immersion pail and cask annulus and is maintained at a pressure slightly higher than the pressure in the loadout pit to minimize contamination.

The MCO locking ring is removed using the locking ring tool. The locking ring tool is calibration tested then installed using the auxiliary hoist. When the locking ring tool is positioned, the grapple attaches to the rim of the locking ring. The hydraulic jacks are actuated by manually rotating the 40 -in. wheel on the locking ring tool. The locking ring is captured in the locking ring tool, and the assembly is removed using the auxiliary hoist. The locking ring tool is surveyed for contamination and placed in an uncontaminated storage area. Approximately 40 gal of de-ionized water from the IWTS are added to the MCO cavity to offset the buoyant effect of water in the cask annular region.

The MCO basket guide is installed in the mouth of the cask-MCO. The basket guide protects the internal shield plug retainer threads and sealing surface as baskets are inserted and aligns the baskets during the loading process.

The immersion pail lift beam is attached to the hooks on the transfer bay crane, and the lift beam is positioned over the immersion pail. The lift beam is set at an elevation that facilitates attachment of the immersion pail lift slings. The hook end of each sling is attached to 
a lift beam master link. The lift beam is slowly raised until there is tension in the slings, then all connections are verified and checked for uneven loading. The immersion pail is raised slowly again until the red alignment lines on the lifting lugs are exposed at the lock pin housings. The locking pin gates are lifted, and the locking pins are pulled out until the pin gates can be closed with the pin in the disengaged position; this ensures full retraction.

De-ionized water from the IWTS is added to the MCO cavity to assist in submersion, then the immersion pail is lowered approximately $2 \mathrm{ft}$ and held in position while the immersion pail lid seal area is checked for leaks. The immersion pail is lowered until it rests on the IPSS bottom plate. The immersion pail slings are removed, then the immersion pail lift beam is removed from the pit area and disconnected from the transfer bay crane hooks.

3.2.2.2 Multi-Canister Overpack Loading. The MCO baskets are moved from the FRS MCO basket queue to the MLS shuttle using the 2-ton flexible transfer crane and the MCO basket stiffback grapple. An underwater camera is used to verify that fuel does not extend above the top of the MCO basket to ensure that the next basket to be loaded will seat properly. Following successful verification, the shuttle is actuated at the MLS control and monitoring station, and the MCO basket is moved from east to west through the transfer channel with the shuttle next to the IPSS. The MLS control and monitoring station is remotely located in corridor 7 .

The gantry mast and grapple assembly is used to load the MCO basket on the shuttle into the cask-MCO. The MCO basket is lifted by extending the mast to the basket and energizing the grapple cylinder. The grapple anti-release mechanism locks automatically. The MCO basket is then lifted approximately $1 \mathrm{in}$. to verify that the load is within the appropriate weight range for the specific MCO basket type using the load cell readout. The MCO basket is lifted to an elevation of approximately the $8 \mathrm{ft} 6 \mathrm{in}$. and centered over the cask-MCO. The shuttle then is returned to a position next to the queue. The MCO basket is lowered to the proper loading position within the MCO.

After the no-load signal is received, the gantry mast is lowered an additional 1.25 in. to disengage the grapple anti-release mechanism. The gantry mast lowers an additional 0.25 in. to completely disengage the grapple. The operator reviews the console display to verify no load on the load cell, correct height position on the controls, and correct grapple motion pin position for release. Following verification, the grapple is opened and the basket is released. The mast is lifted 2 in., and the load cell readout is monitored to verify a " dead load" consisting of mast weight only. Following verification, the mast and the gantry are returned to the shuttle unload position.

This MCO loading process is repeated until the MCO is full. The basket guide is removed from the cask-MCO using a pole hook or rope hook and stored in the transfer bay. A tool rack located along the handrail above the loadout pit platform will be used to store tools.

3.2.2.3 Shield Plug Installation. The shield plug, O-ring, and process tube assembly are assembled in the K Basin transfer bay. The shield plug handling fixture seal is inspected and attached to the shield plug. This handling fixture allows the shield plug to be lifted with a crane, keeps the shield plug top free of contamination during underwater insertion into the $\mathrm{MCO}$, and 
provides a means to decontaminate and dry the area between the fixture and the MCO threads. The lift rig is attached to the shield plug handling fixture and connected to the auxiliary hook on the transfer bay crane. The shield plug assembly is lifted vertically to mezzanine height, placed in the shield plug support stand, and oriented to install the process tube assembly. The shield plug support stand is a fixture attached to the mezzanine that reduces shield plug movement during process tube installation.

The process tube is installed in the shield plug using the mezzanine for access. A mezzanine deck height of $12.5 \mathrm{ft}$ allows the required access to lift the 12.25 - $\mathrm{ft}$-long process tube. The process tube handling tool is used to lift, position, and tighten the process tube. The process tube connection is leak tested to ensure a good seal. A final inspection of the shield plug and o-ring is completed to ensure that they are clean and in good condition. The shield plug seal area on the MCO is cleaned to remove debris.

The shield plug assembly is positioned over the $\mathrm{MCO}$ and lowered into the MCO. The shield plug is checked to ensure proper seating, correct shield plug installation depth, and alignment of the shield plug ports. The lifting rig is released, and the auxiliary hoist is moved out of the way; then the lifting rig is removed from the auxiliary hook.

\subsubsection{Cask-Multi-Canister Overpack Loadout and Preparation for Transfer.}

The immersion pail beam is reattached to the hooks of the transfer bay crane, and the lift beam is positioned over the immersion pail. The hook end of each immersion pail lift sling is attached to the immersion pail lift beam master links. The lift beam is slowly raised until there is tension in the slings; all connections are verified and checked for even loading. The immersion pail is slowly raised to the water surface where the immersion pail lid and shield plug handling fixture surfaces are rinsed thoroughly with de-mineralized water; the shield plug handling fixture top is surveyed for contamination. Following the survey, the pail continues to be raised and rinsed until the red immersion pail lift lug alignment lines are visible over the IPSS locking pin housings. The locking pin gates are then lifted, and the locking pins are extended manually until the gates can close; the pail is lowered until its weight rests on the locking pins. This secures the immersion pail in the upper position. The slings are disconnected, and the ends are fed into the sling storage box. The sling hooks are disconnected and attached to the side of the loadout pit grating structure. The immersion pail lift beam is removed and stored on a portable storage rack that can be moved out of the way of westerly crane travel in the center bay. The shield plug handling fixture is removed from the shield plug. The handling fixture is raised from the MCO, taken from the loadout pit area, and placed in a staging rack.

After the shield plug handling fixture is removed, the locking ring is installed. When the locking ring tool is in position, the locking ring is rotated until seated. When the locking ring is seated, the hydraulic wrenches on the locking ring tool are actuated; simultaneously, the 18 wrenches apply the appropriate torque to the corresponding 18 bolts.

The pressure to the immersion pail lid MCO seal is broken, allowing clean water from the immersion pail water reservoir to flush the seal annulus. The water reservoir is isolated. The immersion pail lid and surrounding area are rinsed thoroughly with de-mineralized water. 
The four immersion pail lid bolts are loosened and captively engaged in the lid. The pressure to the immersion pail lid seal is released. The immersion pail lid sling is attached to the auxiliary hoist and the pail lid. Then the immersion pail lid is slowly raised from the immersion pail and placed in storage on a pedestal inside the curbed decontamination area. The immersion pail lid sling is removed from the transfer bay crane and stored.

The cask water level is adjusted using a suction tool and is verified visually. The transfer bay crane hooks are positioned over the cask lid, then attached to the cask lid trunnions. The cask lid is lifted and positioned over the cask; the alignment with the cask guide pins is verified. The lid is placed on the cask. The transfer bay crane hooks are removed from the cask lid trunnions, and the crane is positioned over the cask lid torque tool. The auxiliary hoist is attached to the cask lid torque tool. The cask lid torque tool is moved over the cask lid and lowered into position for torquing. The lid is fastened to the cask using the cask lid torque tool.

The cask secondary vent port cover is removed in preparation for adding inert gas. When the appropriate gas composition is reached, the cask-MCO meets safety requirements for shipping. Helium is fed into the cask through a multiple-cycle feed-and-bleed process to reduce the oxygen content and prevent the possibility of ignition. The gas adjustment equipment is removed, and the dust cover is replaced. The shipping window begins when the vent port is sealed.

Using the transfer bay crane, the cask is raised from the immersion pail until it can clear the pit wall. Excess water is wiped from the cask as it is removed from the pail. A radiation survey is completed, and the cask is decontaminated if necessary. The cask is moved from the loadout pit to the trailer area. The cask is aligned and lowered into the trailer support device. Just before reaching the trailer deck, cask lowering is halted and the cask tie-down devices are closed. One clamp bolt is installed hand tight on each side. Cask lowering is completed. Any safety chains, handrails, or platforms removed during cask loading operations are reinstalled.

The crane hooks are disconnected, and the crane is positioned away from the trailer area. The vertical tie-downs are connected to the cask. The trailer jacks are raised to allow the tractor to pass under the front of the trailer. The transfer bay roll-up door (No. 157) is opened, the trailer is disconnected from the building compressed air, exhaust trunks are connected as required, and the tractor is positioned under the front of the trailer. The trailer is connected to the tractor, a final release survey is conducted, and the cask is transferred to the Cold Vacuum Drying Facility.

3.2.2.5 Cask Loading System Equipment Maintenance Requirements. The cask operations equipment for the $\mathrm{K}$ Basin loadout pit includes few mechanical systems and requires little maintenance. Maintenance support is limited to that required as a result of system operations inspections performed before each cask loading cycle and other system inspections performed periodically. Components that may require maintenance include immersion pail seal lid seals; immersion pail seal lid fasteners; support structure lock pins; demineralized water reservoir seals, hoses, and connectors; air lines and connectors; and lift slings and pail attachments. However, the integrity of the design and limited operating components make minimal maintenance support necessary (HNF-SD-SNF-OMM-003). 
The MLS has been designed to provide a high degree of system reliability with minimal maintenance, using easily replaceable equipment where maintenance could be required. The shuttle drive system, consisting of a cable, pulleys, and two pneumatic cylinders, has no maintenance requirements. The gantry drive system is a dual rack-and-spur system capable of the significantly faster speeds, cycle times, and loads required for MCO loading. The stainless steel ballscrew, guide shafts, and grapple interface tooling are designed to operate in the K Basin water. Therefore, MLS maintenance mostly consists of periodically confirming that the control equipment setpoints are adjusted correctly for proper system operation. This includes checking the digital and analog inputs and motion control inputs and outputs (HNF-SD-SNF-FDR-003).

In conclusion, routine maintenance activities are expected to result in personnel doses that are small compared to doses incurred during CLS operations. As a result, they are not accounted for in this analysis.

\subsection{INTEGRATED WATER TREATMENT SYSTEM}

\subsubsection{Integrated Water Treatment System Equipment Description}

The IWTS is designed to remove particulate and dissolved materials resulting from the operation of the FRS. The primary components of the IWTS are:

- Three submersible pumps

- Knockout pots

- Underwater particle settler tubes

- Booster pump

- Three particulate filter vessels

- Three ion-exchange modules (IXMs) and associated transfer piping and shielding

- $\quad$ Remote supervisory control and data acquisition system and associated instrumentation.

\subsubsection{Integrated Water Treatment System Operations}

3.3.2.1 Routine Inspection/Tour. The IWTS is inspected twice daily during operations. The inspection consists of a walk-through of the operating area and inspection of system components. Each inspection is expected to last $15 \mathrm{~min}$.

3.3.2.2 Sample Collection. IXM inlet and outlet water samples are collected once a week during system operation. Three of the four IXMs will be in service at any time. Thus, there will be three collection sessions per week. Collected samples are transported to the analytical laboratory. Each collection session is expected to take $20 \mathrm{~min}$. 
3.3.2.3 Filter Purge. When a predetermined differential pressure across a filter vessel or a predetermined dose rate is reached, the control system alarms and the filters are isolated and removed from service. All three filters are purged individually before returning the system to service. Filter purging is accomplished using water, air, or a combination of water and air in various flow paths into and out of the filter vessels. Techniques available for each vessel are the top sparge, full-bed backwash, and air scrub. Purge sequences are selected and controlled remotely by operations personnel. The sequences are fully automatic with no personnel dose resulting, except for the infrequently used air scrub that requires manual action to supply air. The filter vessels have valves and flanges for connecting a compressed air source. Air scrub, when performed, takes about one hour per vessel. However, the time required for an operator to manually connect the air supply and open the valve is $15 \mathrm{~min}$ at most. To accomplish this task, the operator must stand on top of an IXM.

3.3.2.4 Ion-Exchange Module Changeout. Removal of an IXM entails isolating it, draining it to the basin, disconnecting the top and bottom hoses, disconnecting the vent tree, hooking the IXM to the overhead crane, and removing the IXM from the area. Replacing the IXM entails the same steps in reverse. Fifty IXM changeouts per year are expected, with each removal/replacement requiring seven workers (one person-in-charge [PIC], one HPT, one operator, two riggers, and two pipefitters). 
This page intentionally left blank. 


\subsection{DESIGN AND ANALYSIS INPUT}

Radiation doses to personnel carrying out the FRS, CLS, and IWTS activities described in Section 3.0 were computed by multiplying the time each person is in a radiation field during each operational step by the intensity of the field and summing over all the steps. Sections 4.1, 4.2 , and 4.3 document all the input data used to compute personnel doses received during FRS, CLS, and IWTS operations. Doses resulting from FRS and CLS operations were computed on a per MCO basis. Annual and total personnel doses were then inferred by assuming that 100 MCOs per year are filled at each basin and that the SNF in both basins will fill 440 MCOs (220 from each basin).

\subsection{DATA FOR THE FUEL RETRIEVAL SYSTEM}

Integrated personnel doses associated with FRS operations were computed from estimates of processing times, dose rates, and number of personnel involved. Background dose rates measured at various locations in both the K East and K West Basins are listed in Table 4-1. The estimated manpower to complete each step of the fuel retrieval operation is given in Table 4-2. These estimates were based on a time-motion assessment made by $\mathrm{K}$ Basin personnel in 1996 and updated in 1999 (Bullock 1999a). The exposed personnel consist of a PIC providing management oversight, an HPT performing routine surveys, and two operators carrying out the fuel retrieval operations.

Table 4-1. Background Dose Rates at the K Basins.

\begin{tabular}{|c|c|c|c|}
\hline \multirow{2}{*}{ Location } & \multirow{2}{*}{ Abbreviation } & \multicolumn{2}{|c|}{ Dose Rate (mrem/h) } \\
\hline & & K East ${ }^{a}$ & K West ${ }^{b}$ \\
\hline General basin over grating & KGB & 2.00 & 0.125 \\
\hline South Loadout Pit & SLOP & 1.50 & $0.125^{\mathrm{c}}$ \\
\hline South Transfer Area & STA & 1.20 & 0.017 \\
\hline Fuel table area & FRS & 1.80 & 0.090 \\
\hline Standby background & SB & 0.50 & 0.010 \\
\hline Remote operation & REMOTE & 0.00 & 0.000 \\
\hline
\end{tabular}

${ }^{a}$ Dose rates for the $\mathrm{K}$ East Basin were obtained from monthly routine survey K990483, which is listed in Appendix D.

${ }^{b}$ Dose rates for the $\mathrm{K}$ West Basin were obtained from monthly routine survey L990899, except for the SLOP (see footnote c). The survey report is listed in Appendix E.

" No recent survey data were available for the K West Basin SLOP; therefore, the "general basin overgrating" dose rate of $0.125 \mathrm{mrem} / \mathrm{h}$ was conservatively assumed. 
Operational steps 1.01 through 2.14 in Table 4-2 provide personnel times in a radiation zone on a per canister basis; steps 2.15 through 3.07 provide times on a per MCO basket basis. To compute personnel exposures per MCO, it was assumed that an $\mathrm{MCO}$ will contain an average of 5.3 baskets or the SNF from 19 canisters.

Personnel locations associated with each step are also given in Table 4-2. The average radiation exposure each worker receives during each step of the fuel retrieval process can be determined from the given dose locations by referring to Table 4-1.

Personnel carrying out FRS operations will also receive radiation exposure from loaded cask-MCOs when they are raised above the water level in the South Loadout Pit during CLS operations. The dose rates from the MCOs were estimated from an existing shielding analysis of a loaded MCO in a shipping cask (HNF-SD-SNF-CN-026) and a computation of the fraction of time a loaded MCO is exposed during CLS operations. It was assumed that FRS and CLS operations are carried out in parallel and are independent of each other. FRS personnel will usually be more than $30 \mathrm{ft}$ from an exposed cask-MCO, but occasionally will be somewhat closer. A detailed analysis of where personnel might be located during FRS operations relative to an exposed cask-MCO was not done because the resulting dose rates are low. Instead, the dose rate calculated at $10 \mathrm{~m}(30.5 \mathrm{ft})$ from a cask-MCO was taken from Figure 6 in HNF-SD-SNF-CN-026 and used for all FRS operational steps (except those done remotely). This dose rate, $0.25 \mathrm{mrem} / \mathrm{h}$, is conservative; on the average, FRS personnel will be more than $30.5 \mathrm{ft}$ from an exposed cask-MCO and the dose rate calculations were done using a model of a drained cask-MCO. At the K Basins, a cask-MCO always will be flooded with water, which provides additional shielding.

Data on CLS operations given in Section 4.2 indicate that a cask-MCO is exposed (i.e., the elapsed time from when a loaded cask-MCO is raised to the surface of the pool until it is hauled away) for 9.9 hours. Assuming that there are 250 working days per year with operations taking place 22 hours per day and that $100 \mathrm{MCOs}$ are processed per year at each basin, FRS personnel will receive a small radiation dose from cask-MCOs $18 \%$ of the time fuel retrieval activities are taking place. The time-averaged dose rate $10 \mathrm{~m}$ from a cask-MCO is $18 \%$ of $0.25 \mathrm{mrem} / \mathrm{h}$, which is $0.05 \mathrm{mrem} / \mathrm{h}$.

\subsection{DATA FOR THE CASK LOADING SYSTEM}

Integrated personnel doses associated with CLS operations were also computed from estimates of processing times, dose rates, and number of personnel involved. As with the FRS operations, personnel doses come from two sources: background radiation at the $\mathrm{K}$ Basins and the cask-MCOs when above water level during CLS operations. Personnel involved in CLS operations will receive relatively higher dose rates from the cask-MCOs than personnel carrying out FRS activities. As in the FRS analysis, Table 4-1 is the source for background dose rates at both the K East and $\mathrm{K}$ West Basins. Dose rates at various distances from an exposed cask-MCO are listed in Table 4-3, along with a reference for each value. 
Table 4-2. Manpower Requirements and Personnel Locations Associated with each Operation in the Fuel Retrieval Process. (2 sheets)

\begin{tabular}{|c|c|c|c|c|}
\hline Step $^{a}$ & Description of Operation ${ }^{b}$ & $\begin{array}{l}\text { Personnel } \\
\text { Required }\end{array}$ & $\begin{array}{l}\text { Average Time in } \\
\text { Radiation Zone }\end{array}$ & $\begin{array}{c}\text { Dose } \\
\text { Location }^{d}\end{array}$ \\
\hline & Routine management observation & $1 \mathrm{PIC}$ & $6 \mathrm{~h} / \mathrm{MCO}$ & KGB \\
\hline & Routine HPT survey & $1 \mathrm{HPT}$ & $3 \mathrm{~h} / \mathrm{MCO}$ & KGB \\
\hline 1.01 & Get next canister location from chief operator & 2 Operators & $1 \mathrm{~min} / \mathrm{canister}$ & KGB \\
\hline 1.02 & Move underwater light to next canister location & 2 Operators & $1 \mathrm{~min} /$ canister & KGB \\
\hline 1.03 & Locate canister & 2 Operators & $1 \mathrm{~min} / \mathrm{canister}$ & KGB \\
\hline 1.04 & Verify canister location with chief operator & 2 Operators & $0.5 \mathrm{~min} /$ canister & KGB \\
\hline 1.05 & $\begin{array}{l}\text { Move offset hook to canister location ( } 50 \% \text { of } \\
\text { canisters) }\end{array}$ & 2 Operators & $0.25 \mathrm{~min} /$ canister & KGB \\
\hline 1.06 & $\begin{array}{l}\text { Identify receiving in-line canister location }(50 \% \text { of } \\
\text { canisters) }\end{array}$ & 2 Operators & $0.25 \mathrm{~min} /$ canister & KGB \\
\hline 1.07 & Pick up canister with offset hook ( $50 \%$ of canisters) & 2 Operators & $0.5 \mathrm{~min} /$ canister & KGB \\
\hline 1.08 & Move canister to in-line row (50\% of canisters) & 2 Operators & $0.25 \mathrm{~min} /$ canister & KGB \\
\hline 1.09 & Move offset hook out of the way ( $50 \%$ of canisters) & 2 Operators & $0.2 \mathrm{~min} / \mathrm{canister}$ & KGB \\
\hline 1.10 & $\begin{array}{l}\text { Move basin hoist and telescoping stiffback to in-line } \\
\text { canister location }\end{array}$ & 2 Operators & $1 \mathrm{~min} /$ canister & KGB \\
\hline 1.11 & $\begin{array}{l}\text { Pick up canister using basin hoist and telescoping } \\
\text { stiffback }\end{array}$ & 2 Operators & $0.75 \mathrm{~min} /$ canister & KGB \\
\hline 1.12 & Move basin hoist with canister to north wall & 2 Operators & $1.25 \mathrm{~min} /$ canister & KGB \\
\hline 1.13 & Unlock rails as needed & 2 Operators & $0.25 \mathrm{~min} /$ canister & KGB \\
\hline 1.14 & Transfer canister to perimeter trolley & 2 Operators & $0.25 \mathrm{~min} /$ canister & KGB \\
\hline 1.15 & Move canister to cleaning station staging area & 2 Operators & $2 \mathrm{~min} /$ canister & KGB \\
\hline 1.16 & Unlock rails as needed & 2 Operators & $0.25 \mathrm{~min} /$ canister & KGB \\
\hline 1.17 & Transfer canister to rail at cleaning station staging area & 2 Operators & $0.25 \mathrm{~min} /$ canister & KGB \\
\hline 1.18 & Set canister down at cleaning station staging area & 2 Operators & $0.75 \mathrm{~min} /$ canister & FRS \\
\hline 1.19 & Sign accountability form & 2 Operators & $0.5 \mathrm{~min} /$ canister & FRS \\
\hline 1.20 & $\begin{array}{l}\text { Pick up canister previously emptied and take to } \\
\text { cleaning station staging area }\end{array}$ & 2 Operators & $3.5 \mathrm{~min} /$ canister & FRS \\
\hline 1.21 & Take hoist to next canister location & 2 Operators & $3.5 \mathrm{~min} /$ canister & FRS \\
\hline 2.01 & Pick up canister in staging area & 2 Operators & $5 \mathrm{~min} /$ canister & FRS \\
\hline 2.02 & $\begin{array}{l}\text { Put canister in decapper; degas, delid, and dewater } \\
\text { canister (K West only) }\end{array}$ & 2 Operators & $40 \mathrm{~min} /$ canister & FRS \\
\hline 2.03 & Put canister lids in debris basket (K West only) & 2 Operators & $10 \mathrm{~min} /$ canister & FRS \\
\hline 2.04 & Pick up canister out of decapper (K West only) & 2 Operators & $10 \mathrm{~min} /$ canister & FRS \\
\hline 2.05 & Put canister in PCM & 2 Operators & $3 \mathrm{~min} / \mathrm{canister}$ & FRS \\
\hline 2.06 & Close PCM lid and wash & 2 Operators & $2 \mathrm{~min} /$ canister & FRS \\
\hline 2.07 & Open PCM lid and remove canister & 2 Operators & $3 \mathrm{~min} /$ canister & FRS \\
\hline 2.08 & Dump fuel onto inspection table & 2 Operators & $5 \mathrm{~min} /$ canister & FRS \\
\hline
\end{tabular}


Table 4-2. Manpower Requirements and Personnel Locations Associated with each Operation in the Fuel Retrieval Process. ( 2 sheets)

\begin{tabular}{|c|c|c|c|c|}
\hline Step $^{a}$ & Description of Operation ${ }^{b}$ & $\begin{array}{l}\text { Personnel } \\
\text { Required }\end{array}$ & $\begin{array}{l}\text { Average Time in } \\
\text { Radiation Zone }\end{array}$ & $\begin{array}{c}\text { Dose } \\
\text { Location }^{d}\end{array}$ \\
\hline 2.09 & Verify canister is empty; set canister aside & 2 Operators & $3 \mathrm{~min} /$ canister & FRS \\
\hline 2.10 & $\begin{array}{l}\text { Remove stuck fuel in canister if needed; put fuel in } \\
\text { PCM }\end{array}$ & 2 Operators & $10 \mathrm{~min} /$ canister & FRS \\
\hline 2.11 & Close PCM lid and wash & 2 Operators & $2 \mathrm{~min} /$ canister & FRS \\
\hline 2.12 & Separate fuel elements (remote operation) & 2 Operators & $15 \mathrm{~min} /$ canister & REMOTE \\
\hline 2.13 & Inspect elements (remote operation) & 2 Operators & $12 \mathrm{~min} /$ canister & REMOTE \\
\hline 2.14 & Rewash fuel, if needed & 2 Operators & $10 \mathrm{~min} /$ canister & FRS \\
\hline 3.07 & Record new MCO basket number & 2 Operators & $2 \mathrm{~min} /$ basket & FRS \\
\hline 2.15 & Load MCO basket with fuel (remote operation) & 2 Operators & $9 \mathrm{~h} /$ basket & REMOTE \\
\hline 3.01 & $\begin{array}{l}\text { Pick up full MCO basket with basket hoist and } \\
\text { stiffback grapple }\end{array}$ & 2 Operators & $1.5 \mathrm{~min} /$ basket & FRS \\
\hline 3.02 & Weigh full MCO basket and record weight & 2 Operators & $2 \mathrm{~min} /$ basket & FRS \\
\hline 3.03 & Videotape full MCO basket & 2 Operators & $1 \mathrm{~min} /$ basket & FRS \\
\hline 3.04 & Move full MCO basket south on rail & 2 Operators & $0.5 \mathrm{~min} /$ basket & FRS \\
\hline 3.05 & $\begin{array}{l}\text { Transfer full MCO basket to trolley, take to MCO load } \\
\text { staging }\end{array}$ & 2 Operators & $5 \mathrm{~min} /$ basket & FRS \\
\hline 3.06 & $\begin{array}{l}\text { Pick up new, empty MCO basket, take to inspection } \\
\text { table }\end{array}$ & 2 Operators & $5 \mathrm{~min} /$ basket & FRS \\
\hline
\end{tabular}

${ }^{a}$ Step numbers refer to those given in Table 3-1.

b More detail on each step is given in Section 3.1.2.

${ }^{\mathrm{c}}$ Step times are from an assessment by K Basin personnel (Bullock 1999a).

${ }^{d}$ Dose location designators are defined in Table 4-1.

HPT $=$ health physics technician.

PCM = primary clean machine.

$\mathrm{MCO}=$ multi-canister overpack.

$\mathrm{PIC}=$ person-in-charge. 
Table 4-3. Dose Rates from a Filled Cask-Multi-Canister Overpack that is Exposed.

\begin{tabular}{|c|c|c|c|}
\hline Description & $\begin{array}{l}\text { Distance from } \\
\text { Cask-MCO (m) }\end{array}$ & $\begin{array}{l}\text { Dose Rate } \\
(\mathrm{mrem} / \mathrm{h})\end{array}$ & Reference \\
\hline \multirow{4}{*}{$\begin{array}{l}\text { Above cask; cask lid off, } \\
\text { no MCO ring }\end{array}$} & 1.0 & 10.0 & \multirow[t]{4}{*}{ HNF-SD-SNF-CN-026, Figures 6 and $7^{\mathrm{a}}$} \\
\hline & 2.0 & 4.0 & \\
\hline & 3.0 & 2.0 & \\
\hline & 5.0 & 0.8 & \\
\hline $\begin{array}{l}\text { Top of cask; cask lid off, } \\
\text { MCO ring installed }\end{array}$ & Contact & 1.3 & HNF-SD-SNF-CN-026, Table 8B ${ }^{\mathrm{a}}$ \\
\hline \multirow[t]{2}{*}{$\begin{array}{l}\text { Above cask; cask lid on, } \\
\text { MCO ring installed }\end{array}$} & 0.3 & 0.2 & $\begin{array}{l}\text { SNF Canister Storage Building ALARA } \\
\text { Analysis 09, Table } 2 \text { (FDI 1998) }\end{array}$ \\
\hline & 1.0 & 0.1 & $\begin{array}{l}\text { SNF Canister Storage Building ALARA } \\
\text { Analysis 09, Table } 2 \text { (FDI 1998) }\end{array}$ \\
\hline \multirow[t]{3}{*}{ At side of cask ${ }^{c}$} & 1.0 & 7.0 & \multirow[t]{3}{*}{ HNF-SD-SNF-CN-026, Figure $6^{a}$} \\
\hline & 2.0 & 3.5 & \\
\hline & 5.0 & 0.9 & \\
\hline
\end{tabular}

${ }^{a}$ HNF-SD-SNF-CN-026, 1997, MCO Shield Plug Dose Rate Analysis, Rev. 0, Fluor Daniel Northwest, Inc., for Fluor Daniel Hanford, Incorporated, Richland, Washington.

${ }^{\mathrm{b}}$ FDI, 1998, SNF Canister Storage Building ALARA Analysis 09, Fluor Daniel, Inc., Richland, Washington.

${ }^{\mathrm{c}}$ Dose rates given at distances from the side of the cask were computed using a model that had the cask lid and the MCO ring off. However, they are applied in situations where the lid and ring are installed. The cask lid and MCO ring have only a small effect on dose rates at the side of the cask, and the effect is in the conservative direction.

ALARA $=$ as low as reasonably achievable.

CSB $=$ Canister Storage Building.

$\mathrm{MCO}=$ multi-canister overpack.

The estimated manpower to complete each step of the cask-MCO loading operation is given in Table 4-4. These estimates were based on a time-motion assessment completed by K Basin personnel in 1996 and updated in 1999 (Bullock 1999a). The exposed personnel consist of a PIC providing management oversight, an HPT performing routine surveys, and two operators carrying out the cask-MCO loading operations. Personnel locations associated with each operational step and distances from an exposed cask-MCO also are given in Table 4-4. The average radiation exposure each worker receives during each step of the CLS operation can be determined using data from Tables 4-1 and 4-4. 
Table 4-4. Manpower Requirements and Personnel Locations Associated with each Cask Loading System Operation. (4 sheets)

\begin{tabular}{|c|c|c|c|c|c|}
\hline Step ${ }^{a}$ & Description & $\begin{array}{c}\text { Time } \\
(\min / \mathbf{M C O})\end{array}$ & $\begin{array}{l}\text { Personnel } \\
\text { Required }\end{array}$ & $\begin{array}{c}\text { Dose } \\
\text { Location }^{b}\end{array}$ & $\begin{array}{c}\text { Distance (m) } \\
\text { from Cask- } \\
\text { MCO }^{c}\end{array}$ \\
\hline & Routine management observation & 60 & PIC & KBG & \\
\hline & Routine HPT survey & 120 & HPT & KBG & \\
\hline 1.01 & Prepare receiving area & 60 & $\begin{array}{l}\text { Operator } 1 \\
\text { Operator } 2\end{array}$ & $\begin{array}{l}\text { STA } \\
\text { STA }\end{array}$ & \\
\hline 1.02 & Back trailer in & 10 & $\begin{array}{c}\text { Operator } 1 \\
\text { Operator } 2 \\
\text { HPT } \\
\text { Truck driver }\end{array}$ & $\begin{array}{l}\text { STA } \\
\text { SB } \\
\text { SB } \\
\text { SB }\end{array}$ & \\
\hline 1.03 & Prepare to separate trailer & 20 & $\begin{array}{c}\text { Operator } 1 \\
\text { Operator } 2 \\
\text { HPT } \\
\text { Truck driver }\end{array}$ & $\begin{array}{c}\text { STA } \\
\text { STA } \\
\text { SB } \\
\text { SB }\end{array}$ & \\
\hline 1.04 & Separate trailer and remove tractor & 20 & $\begin{array}{c}\text { Operator 1 } \\
\text { Operator } 2 \\
\text { HPT } \\
\text { Truck driver }\end{array}$ & $\begin{array}{c}\text { STA } \\
\text { SB } \\
\text { SB } \\
\text { SB }\end{array}$ & \\
\hline 1.05 & Level trailer and close roll-up door & 10 & $\begin{array}{c}\text { Operator } 1 \\
\text { Operator } 2 \\
\text { HPT }\end{array}$ & $\begin{array}{l}\text { STA } \\
\text { SB } \\
\text { SB }\end{array}$ & \\
\hline 1.06 & Perform a radiation survey of the cask & 10 & $\begin{array}{c}\text { Operator } 1 \\
\text { Operator } 2 \\
\text { HPT }\end{array}$ & $\begin{array}{l}\text { STA } \\
\text { SB } \\
\text { STA }\end{array}$ & \\
\hline 1.07 & Release cask tie-downs & 10 & $\begin{array}{c}\text { Operator } 1 \\
\text { Operator } 2 \\
\text { HPT }\end{array}$ & $\begin{array}{c}\text { STA } \\
\text { STA } \\
\text { SB } \\
\end{array}$ & \\
\hline 1.08 & Attach 32-ton crane to cask lid & 10 & $\begin{array}{c}\text { Operator } 1 \\
\text { Operator } 2 \\
\text { HPT }\end{array}$ & $\begin{array}{c}\text { STA } \\
\text { STA } \\
\text { SB }\end{array}$ & \\
\hline 1.09 & Disconnect clamshell & 10 & $\begin{array}{c}\text { Operator } 1 \\
\text { Operator } 2 \\
\text { HPT }\end{array}$ & $\begin{array}{c}\text { STA } \\
\text { STA } \\
\text { SB }\end{array}$ & \\
\hline 1.10 & Lift cask and move to loadout pit & 20 & $\begin{array}{c}\text { Operator } 1 \\
\text { Operator } 2 \\
\text { HPT }\end{array}$ & $\begin{array}{c}\text { STA } \\
\text { SB } \\
\text { SB } \\
\end{array}$ & \\
\hline 1.11 & Inspect IP & 15 & $\begin{array}{c}\text { Operator } 1 \\
\text { Operator } 2 \\
\text { HPT }\end{array}$ & $\begin{array}{l}\text { SLOP } \\
\text { SLOP } \\
\text { SB }\end{array}$ & \\
\hline 1.12 & Put cask into IP & 10 & $\begin{array}{c}\text { Operator 1 } \\
\text { Operator } 2 \\
\text { HPT }\end{array}$ & $\begin{array}{c}\text { SLOP } \\
\text { SB } \\
\text { SB }\end{array}$ & \\
\hline 1.13 & $\begin{array}{l}\text { Retrieve torque tool, loosen lid bolts, } \\
\text { remove tool, and disconnect hoist }\end{array}$ & 35 & $\begin{array}{c}\text { Operator } 1 \\
\text { Operator } 2 \\
\text { HPT }\end{array}$ & $\begin{array}{l}\text { SLOP } \\
\text { SLOP } \\
\text { SLOP }\end{array}$ & \\
\hline
\end{tabular}


Table 4-4. Manpower Requirements and Personnel Locations Associated with each Cask Loading System Operation. (4 sheets)

\begin{tabular}{|c|c|c|c|c|c|}
\hline Step $^{a}$ & Description & $\underset{(\min / \mathrm{MCO})}{\operatorname{Time}}$ & $\begin{array}{l}\text { Personnel } \\
\text { Required }\end{array}$ & $\begin{array}{c}\text { Dose } \\
\text { Location }^{b}\end{array}$ & $\begin{array}{l}\text { Distance (m) } \\
\text { from Cask- } \\
\text { MCO' }^{c}\end{array}$ \\
\hline 1.14 & Attach lid slings & 5 & $\begin{array}{c}\text { Operator } 1 \\
\text { Operator } 2 \\
\text { HPT } \\
\end{array}$ & $\begin{array}{l}\text { SLOP } \\
\text { SLOP } \\
\text { SLOP } \\
\end{array}$ & \\
\hline 1.15 & Remove cask lid and store & 15 & $\begin{array}{c}\text { Operator } 1 \\
\text { Operator } 2 \\
\text { HPT }\end{array}$ & $\begin{array}{l}\text { SLOP } \\
\text { SLOP } \\
\text { SLOP } \\
\end{array}$ & \\
\hline 1.16 & Remove 32-ton crane & 5 & $\begin{array}{c}\text { Operator } 1 \\
\text { Operator } 2 \\
\text { HPT }\end{array}$ & $\begin{array}{l}\text { SLOP } \\
\text { SLOP } \\
\text { SLOP } \\
\end{array}$ & \\
\hline 1.17 & Connect to IP lid, install, and test & 50 & $\begin{array}{c}\text { Operator } 1 \\
\text { Operator } 2 \\
\text { HPT }\end{array}$ & $\begin{array}{l}\text { SLOP } \\
\text { SLOP } \\
\text { SLOP }\end{array}$ & \\
\hline 1.18 & Fill IP with water & 10 & $\begin{array}{c}\text { Operator } 1 \\
\text { Operator } 2 \\
\text { HPT }\end{array}$ & $\begin{array}{l}\text { STA } \\
\text { SB } \\
\text { SB }\end{array}$ & \\
\hline 1.19 & $\begin{array}{l}\text { Remove locking ring with locking } \\
\text { ring tool and store }\end{array}$ & 50 & $\begin{array}{c}\text { Operator } 1 \\
\text { Operator } 2 \\
\text { HPT } \\
\end{array}$ & $\begin{array}{l}\text { SLOP } \\
\text { SLOP } \\
\text { SLOP } \\
\end{array}$ & \\
\hline 1.20 & $\begin{array}{l}\text { Fill MCO with water, install basket } \\
\text { guide }\end{array}$ & 25 & $\begin{array}{c}\text { Operator } 1 \\
\text { Operator } 2 \\
\text { IIPT } \\
\end{array}$ & $\begin{array}{c}\text { SLOP } \\
\text { SLOP } \\
\text { SB } \\
\end{array}$ & \\
\hline 1.21 & Connect 32-ton crane to IP with slings & 30 & $\begin{array}{c}\text { Operator } 1 \\
\text { Operator } 2 \\
\text { HPT } \\
\end{array}$ & $\begin{array}{l}\text { SLOP } \\
\text { SLOP } \\
\text { SLOP }\end{array}$ & \\
\hline 1.22 & Release lock pins & 10 & $\begin{array}{c}\text { Operator } 1 \\
\text { Operator } 2 \\
\text { HPT } \\
\end{array}$ & $\begin{array}{c}\text { SLOP } \\
\text { SLOP } \\
\text { SB }\end{array}$ & \\
\hline 1.23 & Lower IP system to bottom & 10 & $\begin{array}{c}\text { Operator } 1 \\
\text { Operator } 2 \\
\text { HPT }\end{array}$ & $\begin{array}{l}\text { STA } \\
\text { SB } \\
\text { SB } \\
\end{array}$ & \\
\hline 1.24 & $\begin{array}{l}\text { Remove lift beam, slings, and IP from } \\
\text { 32-ton crane and store }\end{array}$ & 25 & $\begin{array}{c}\text { Operator } 1 \\
\text { Operator } 2 \\
\text { HPT }\end{array}$ & $\begin{array}{l}\text { SLOP } \\
\text { SLOP } \\
\text { SLOP } \\
\end{array}$ & \\
\hline $\begin{array}{l}2.01 \text { to } \\
2.09\end{array}$ & Load MCO with fuel or scrap baskets & 275 & $\begin{array}{c}\text { Operator } 1 \\
\text { Operator } 2 \\
\text { HPT }\end{array}$ & $\begin{array}{c}\text { STA } \\
\text { STA } \\
\text { SB }\end{array}$ & \\
\hline 3.01 & Prepare MCO shield plug & 100 & $\begin{array}{c}\text { Operator } 1 \\
\text { Operator } 2 \\
\text { HPT }\end{array}$ & $\begin{array}{c}\text { STA } \\
\text { STA } \\
\text { SB }\end{array}$ & \\
\hline 3.02 & $\begin{array}{l}\text { Remove MCO basket guide and clean } \\
\text { plug sealing area }\end{array}$ & 30 & $\begin{array}{c}\text { Operator } 1 \\
\text { Operator } 2 \\
\text { HPT } \\
\end{array}$ & $\begin{array}{l}\text { SLOP } \\
\text { SLOP } \\
\text { SLOP }\end{array}$ & \\
\hline 3.03 & Install MCO shield plug & 15 & $\begin{array}{c}\text { Operator } 1 \\
\text { Operator } 2 \\
\text { HPT }\end{array}$ & $\begin{array}{c}\text { STA } \\
\text { STA } \\
\text { SB }\end{array}$ & \\
\hline
\end{tabular}


Table 4-4. Manpower Requirements and Personnel Locations Associated with each Cask Loading System Operation. (4 sheets)

\begin{tabular}{|c|c|c|c|c|c|}
\hline Step" & Description & $\begin{array}{c}\text { Time } \\
(\mathrm{min} / \mathbf{M C O})\end{array}$ & $\begin{array}{l}\text { Personnel } \\
\text { Required }\end{array}$ & $\begin{array}{c}\text { Dose } \\
\text { Location }^{\mathrm{b}}\end{array}$ & $\begin{array}{c}\text { Distance (m) } \\
\text { from Cask- } \\
\text { MCO }^{\mathbf{c}}\end{array}$ \\
\hline $\begin{array}{l}3.04 \\
\text { and } \\
4.01\end{array}$ & $\begin{array}{l}\text { Remove plug lift rig and connect IP } \\
\text { lift beam and slings }\end{array}$ & 35 & $\begin{array}{c}\text { Operator } 1 \\
\text { Operator } 2 \\
\text { HPT }\end{array}$ & $\begin{array}{l}\text { SLOP } \\
\text { SLOP } \\
\text { SLOP }\end{array}$ & \\
\hline 4.02 & Raise IP to pool surface & 10 & $\begin{array}{c}\text { Operator } 1 \\
\text { Operator } 2 \\
\text { HPT }\end{array}$ & $\begin{array}{l}\text { STA } \\
\text { STA } \\
\text { STA }\end{array}$ & $\begin{array}{l}3 \text { above } \\
3 \text { above }\end{array}$ \\
\hline 4.03 & Rinse MCO top and IP lid & 10 & $\begin{array}{c}\text { Operator } 1 \\
\text { Operator } 2 \\
\text { HPT }\end{array}$ & $\begin{array}{l}\text { SLOP } \\
\text { SLOP } \\
\text { SLOP }\end{array}$ & $\begin{array}{l}3 \text { above } \\
3 \text { above } \\
3 \text { above }\end{array}$ \\
\hline$\overline{4.04}$ & Raise IP and pin in upper position & 10 & $\begin{array}{c}\text { Operator } 1 \\
\text { Operator } 2 \\
\text { HPT }\end{array}$ & $\begin{array}{l}\text { SLOP } \\
\text { SLOP } \\
\text { SLOP }\end{array}$ & $\begin{array}{l}1 \text { above } \\
1 \text { above } \\
3 \text { above }\end{array}$ \\
\hline 4.05 & Remove lift slings and beam and store & 20 & $\begin{array}{c}\text { Operator } 1 \\
\text { Operator } 2 \\
\text { HPT }\end{array}$ & $\begin{array}{l}\text { SLOP } \\
\text { SLOP } \\
\text { SLOP }\end{array}$ & $\begin{array}{l}1 \text { above } \\
1 \text { above } \\
1 \text { above }\end{array}$ \\
\hline 4.06 & $\begin{array}{l}\text { Decontaminate MCO shield plug and } \\
\text { IP lid }\end{array}$ & 15 & $\begin{array}{c}\text { Operator } 1 \\
\text { Operator } 2 \\
\text { HPT }\end{array}$ & $\begin{array}{l}\text { SLOP } \\
\text { SLOP } \\
\text { SLOP } \\
\end{array}$ & $\begin{array}{l}1 \text { above } \\
1 \text { above } \\
1 \text { above }\end{array}$ \\
\hline$\overline{4.07}$ & Clean threads and install locking ring & 85 & $\begin{array}{c}\text { Operator } 1 \\
\text { Operator } 2 \\
\text { HPT }\end{array}$ & $\begin{array}{l}\text { SLOP } \\
\text { SLOP } \\
\text { SLOP }\end{array}$ & $\begin{array}{l}1 \text { above } \\
1 \text { above } \\
1 \text { above }\end{array}$ \\
\hline 4.08 & Deflate IP lid seals and remove bolts & 35 & $\begin{array}{c}\text { Operator } 1 \\
\text { Operator } 2 \\
\text { HPT }\end{array}$ & $\begin{array}{l}\text { SLOP } \\
\text { SLOP } \\
\text { SLOP }\end{array}$ & $\begin{array}{l}0 \text { above } \\
0 \text { above } \\
0 \text { above }\end{array}$ \\
\hline 4.09 & Remove IP lid & 25 & $\begin{array}{c}\text { Operator } 1 \\
\text { Operator } 2 \\
\text { HPT }\end{array}$ & $\begin{array}{l}\text { SLOP } \\
\text { SLOP } \\
\text { SLOP }\end{array}$ & $\begin{array}{l}0 \text { above } \\
0 \text { above } \\
0 \text { above }\end{array}$ \\
\hline 4.10 & $\begin{array}{l}\text { Adjust cask water level with suction } \\
\text { tool }\end{array}$ & 15 & $\begin{array}{c}\text { Operator } 1 \\
\text { Operator } 2 \\
\text { HPT }\end{array}$ & $\begin{array}{l}\text { SLOP } \\
\text { SLOP } \\
\text { SLOP }\end{array}$ & $\begin{array}{l}0 \text { above } \\
0 \text { above } \\
0 \text { above }\end{array}$ \\
\hline 4.11 & Install cask lid and torque bolts & 85 & $\begin{array}{c}\text { Operator } 1 \\
\text { Operator } 2 \\
\text { HPT }\end{array}$ & $\begin{array}{l}\text { SLOP } \\
\text { SLOP } \\
\text { SLOP }\end{array}$ & $\begin{array}{l}1 \text { above } \\
1 \text { above } \\
1 \text { above }\end{array}$ \\
\hline 4.12 & $\begin{array}{l}\text { Open cask port cover and adjust gas } \\
\text { composition }\end{array}$ & 35 & $\begin{array}{c}\text { Operator } 1 \\
\text { Operator } 2 \\
\text { HPT }\end{array}$ & $\begin{array}{l}\text { SLOP } \\
\text { SLOP } \\
\text { SLOP }\end{array}$ & $\begin{array}{l}1 \text { above } \\
1 \text { above } \\
1 \text { above }\end{array}$ \\
\hline 4.13 & Attach crane to cask and raise from IP & 20 & $\begin{array}{c}\text { Operator } 1 \\
\text { Operator } 2 \\
\text { HPT }\end{array}$ & $\begin{array}{l}\text { SLOP } \\
\text { SB } \\
\text { SLOP }\end{array}$ & $\begin{array}{l}2 \text { from side } \\
1 \text { from side }\end{array}$ \\
\hline$\overline{4.14}$ & Dry, survey, and smear cask surface & 105 & $\begin{array}{c}\text { Operator } 1 \\
\text { Operator } 2 \\
\text { HPT }\end{array}$ & $\begin{array}{l}\text { STA } \\
\text { STA } \\
\text { STA }\end{array}$ & $\begin{array}{l}1 \text { from side } \\
2 \text { from side } \\
1 \text { from side }\end{array}$ \\
\hline 4.15 & Move cask and tie-down on trailer & 60 & $\begin{array}{c}\text { Operator } 1 \\
\text { Operator } 2 \\
\text { HPT }\end{array}$ & $\begin{array}{l}\text { STA } \\
\text { STA } \\
\text { STA }\end{array}$ & $\begin{array}{l}1 \text { from side } \\
1 \text { from side } \\
2 \text { from side }\end{array}$ \\
\hline
\end{tabular}


Table 4-4. Manpower Requirements and Personnel Locations Associated with each Cask Loading System Operation. (4 sheets)

\begin{tabular}{|c|c|c|c|c|c|}
\hline Step ${ }^{a}$ & Description & $\begin{array}{c}\text { Time } \\
(\mathbf{m i n} / \mathbf{M C O})\end{array}$ & $\begin{array}{l}\text { Personnel } \\
\text { Required }\end{array}$ & $\begin{array}{c}\text { Dose } \\
\text { Location }^{b}\end{array}$ & $\begin{array}{c}\text { Distance (m) } \\
\text { from Cask- } \\
\text { MCO }^{c}\end{array}$ \\
\hline 4.16 & Connect tractor to trailer & 45 & $\begin{array}{c}\text { Operator } 1 \\
\text { HPT } \\
\text { Truck driver }\end{array}$ & $\begin{array}{c}\text { STA } \\
\text { STA } \\
\text { SB }\end{array}$ & $\begin{array}{l}2 \text { from side } \\
2 \text { from side } \\
2 \text { from side }\end{array}$ \\
\hline 4.17 & Perform final radiation survey & 20 & $\begin{array}{c}\text { Operator } 1 \\
\text { Operator } 2 \\
\text { HPT }\end{array}$ & $\begin{array}{l}\text { STA } \\
\text { STA } \\
\text { STA }\end{array}$ & $\begin{array}{l}2 \text { from side } \\
2 \text { from side } \\
1 \text { from side }\end{array}$ \\
\hline 4.18 & Release cask for transfer to CVDF & 5 & $\begin{array}{c}\text { Operator } 1 \\
\text { Operator } 2 \\
\text { HPT } \\
\text { Truck driver }\end{array}$ & $\begin{array}{c}\text { STA } \\
\text { STA } \\
\text { STA } \\
\text { SB }\end{array}$ & $\begin{array}{l}5 \text { from side } \\
5 \text { from side } \\
5 \text { from side }\end{array}$ \\
\hline 4.19 & Drive tractor/trailer away & 5 & $\begin{array}{c}\text { Operator 1 } \\
\text { HPT } \\
\text { Truck driver }\end{array}$ & $\begin{array}{l}\text { STA } \\
\text { STA } \\
\text { SB }\end{array}$ & $\begin{array}{l}5 \text { from side } \\
5 \text { from side }\end{array}$ \\
\hline
\end{tabular}

${ }^{a}$ Step numbers refer to those listed in Table 3-2.

${ }^{\mathrm{b}}$ See Table 4-1 for definitions of the dose location designators.

${ }^{\mathrm{C}}$ Cask-MCO-to-worker distances are given only if a filled cask-MCO is at or above the basin water level and the worker is close enough to receive a significant dose. See Table 4-3 for the dose rates associated with each given distance. Several sets of dose rates are listed in Table 4-3. Dose rates from Table 4-3 were applied assuming the following:

(1) The cask lid and the MCO locking ring were not installed before step 4.07 was completed

(2) The MCO ring was installed, but the cask lid was off during steps 4.08 through 4.10 ,

(3) Both the MCO ring and the cask lid were installed during and atter steps 4.11

(4) In steps 4.02 through 4.12, only the top of the cask-MCO is above the surface of the water; from step 4.13 on, the entire cask-MCO is out of the water.

CVDF $=$ Cold Vacuum Drying Facility.

HPT $=$ health physics technician.

$\mathrm{IP}=$ immersion pail.

$\mathrm{MCO}=$ multi-canister overpack.

$\mathrm{PIC}=$ person-in - charge.

\subsection{OPERATIONS DATA FOR THE INTEGRATED WATER TREATMENT SYSTEM}

Activities associated with the operation and maintenance of the K West IWTS are outlined in Section 3.3.2. In addition to the $\mathrm{K}$ West Basin background radiation, IWTS personnel involved in IXM replacements and sample collection may receive a significant dose from radioactive materials entrapped in the IXMs. Dose rates around a loaded IXM are listed in Table 4-5. These data, which were applied in this analysis, are based on measurements for existing IXMs at the K Basins. 
Table 4-5. Dose Rates in Vicinity of a Loaded Integrated Water Treatment System Ion Exchange Module.

\begin{tabular}{|l|c|c|c|l|}
\hline \multicolumn{1}{|c|}{ Location } & Abbreviation & $\begin{array}{c}\text { Distance (m) } \\
\text { from IXM }\end{array}$ & $\begin{array}{c}\text { Dose rate } \\
\text { (mrem/h) }\end{array}$ & \multicolumn{1}{|c|}{ Reference } \\
\hline Outlet side of IXM & OLS & 0.3 & 20 & $\begin{array}{l}\text { SNF Project Radiological Survey } \\
\text { Report No. K990564 }\end{array}$ \\
\cline { 3 - 5 } & & 1.0 & 6.0 & Computed $^{\mathrm{a}}$ \\
\hline Other three sides off IXM & SIDE & 0.3 & 10 & $\begin{array}{l}\text { SNF Project Radiological Survey } \\
\text { Report Nos. K990552, K990556 } \\
\text { and K990559 }^{\mathrm{a}}\end{array}$ \\
\hline Above IXM & TOP & 1.0 & 4.6 & Computed $^{\mathrm{b}}$ \\
\hline $\begin{array}{l}\text { Far enough from IXM that no } \\
\text { significant dose is received }\end{array}$ & REMOTE & $>3.0$ & 1.5 & $\begin{array}{l}\text { SNF Project Radiological Survey } \\
\text { Report No. K990552 }^{\mathrm{a}}\end{array}$ \\
\hline
\end{tabular}

${ }^{a}$ Relevant pages from SNF Project Radiological Survey Reports K990552, K990556, K990559 and K990564 are listed in Appendix F.

${ }^{\mathrm{b}}$ Dose rate computations are described in Appendix G.

IXM $=$ ion exchange module.

$\mathrm{SNF}=$ spent nuclear fuel.

Information on the number of personnel involved in each IWTS activity, their locations and the time necessary in a radiation zone was obtained from the IWTS ALARA report (Kensicki 1997) or a more recent assessment (Bullock 1999b). Data necessary to compute personnel doses anticipated for each activity are given in Table 4-5, 4-6 and 4-7. Tables 4-5 and 4-6 provide common information, while Table 4-7 provides detailed information on the IXM change-out operation, which is more complex than other IWTS-related activities.

A routine inspection tour of ITWS equipment is made twice a day. Each tour was estimated to take one operator $15 \mathrm{~min}$ to complete (Kensicki 1997). To estimate the average dose rate to the operator during a tour, it was assumed that the operator will not spend significant time near an IXM or filter vessel. The dose rate applied is then the background for the south transfer area, which is $0.017 \mathrm{mrem} / \mathrm{h}$ (Table 4-1). Water samples are collected weekly from the inlet and outlet of each IXM that is on-line. Three of the four IXMs will be in service at any time. Sample collection will take one operator accompanied by an HPT 20 min per IXM. The operator and HPT are assumed to be $1 \mathrm{ft}$ from the IXMs while collecting the samples. Thus, from Tables 4-5 and 4-6 the estimated dose rate is $10 \mathrm{mrem} / \mathrm{h}$ plus an insignificant $0.017 \mathrm{mrem} / \mathrm{h}$ background. 
Table 4-6. Manpower and Personnel Location Requirements for Integrated Water Treatment System Operations and Maintenance.

\begin{tabular}{|l|c|c|c|c|c|}
\hline \multicolumn{1}{|c|}{ Activity } & $\begin{array}{c}\text { Personnel } \\
\text { Required }\end{array}$ & $\begin{array}{c}\text { Time } \\
\text { Required } \\
\text { (min) }\end{array}$ & Frequency & $\begin{array}{c}\text { Dose } \\
\text { Background } \\
\text { Location (see } \\
\text { Table 4-1) }\end{array}$ & $\begin{array}{c}\text { Location and } \\
\text { Distance (m) } \\
\text { from IXM (see } \\
\text { Table 4-5) }\end{array}$ \\
\hline Routine inspection/tour & Operator & 15 & $2 /$ day & STA & REMOTE \\
\hline $\begin{array}{l}\text { Sample collection } \\
\text { Filter purge (air scrub option } \\
\text { only) }\end{array}$ & $\begin{array}{c}\text { Operator } \\
\text { HPT }\end{array}$ & 20 & $3 /$ week & STA & SIDE - 1 \\
\hline $\begin{array}{l}\text { Ion-Exchange Module } \\
\text { changeout }\end{array}$ & $*$ & 15 & $<1 /$ month & STA & TOP -0.3 \\
\hline
\end{tabular}

*See Table 4-7 for details on IXM changeout.

HPT = health physics technician.

IXM $=$ ion exchange module. 
Table 4-7. Manpower Estimates and Dose Rates for an Integrated Water Treatment System Ion Exchange Module Changeout. (2 sheets)

\begin{tabular}{|c|c|c|c|c|c|}
\hline Step & Description & $\begin{array}{l}\text { Duration } \\
\text { (min) }\end{array}$ & Personnel & $\begin{array}{c}\text { Background } \\
\text { Dose } \\
\text { Location" }\end{array}$ & $\begin{array}{l}\text { Location and } \\
\text { Distance (m) } \\
\text { from IXM }^{\mathrm{b}}\end{array}$ \\
\hline 1 & Valve out and drain IXM & 15 & $\begin{array}{l}1 \text { operator } \\
1 \mathrm{HPT}\end{array}$ & $\begin{array}{l}\text { STA } \\
\text { STA }\end{array}$ & $\begin{array}{l}\mathrm{OSL}-1.0 \\
\mathrm{OSL}-1.0\end{array}$ \\
\hline 2 & Prepare work area & 10 & $\begin{array}{l}1 \text { operator } \\
1 \mathrm{HPT}\end{array}$ & $\begin{array}{l}\text { STA } \\
\text { STA }\end{array}$ & $\begin{array}{l}\mathrm{OSL}-1.0 \\
\mathrm{OSL}-1.0\end{array}$ \\
\hline 3 & $\begin{array}{l}\text { Disconnect outlet hose, remove 3-in. } \\
\text { pipe, install cap and plug }\end{array}$ & 20 & $\begin{array}{l}1 \mathrm{PIC} \\
1 \text { operator } \\
1 \mathrm{HPT} \\
2 \text { pipefitters }\end{array}$ & $\begin{array}{c}\text { SB } \\
\text { STA } \\
\text { STA } \\
\text { STA }\end{array}$ & $\begin{array}{l}\text { REMOTE } \\
\text { OLS }-1.0 \\
\text { OLS }-1.0 \\
\text { OLS }-0.3\end{array}$ \\
\hline 4 & $\begin{array}{l}\text { Disconnect inlet hose, remove 3-in. } \\
\text { pipe, install cap and plug }\end{array}$ & 15 & $\begin{array}{l}1 \text { PIC } \\
1 \text { operator } \\
1 \text { HPT } \\
2 \text { pipefitters }\end{array}$ & $\begin{array}{l}\text { SB } \\
\text { STA } \\
\text { STA } \\
\text { STA }\end{array}$ & $\begin{array}{l}\text { REMOTE } \\
\text { REMOTE } \\
\text { TOP }-0.3 \\
\text { TOP }-0.3\end{array}$ \\
\hline 5 & Disconnect vent tree and store. & 10 & $\begin{array}{l}1 \mathrm{PIC} \\
1 \text { operator } \\
1 \mathrm{HPT} \\
2 \text { pipefitters }\end{array}$ & $\begin{array}{c}\text { SB } \\
\text { STA } \\
\text { STA } \\
\text { STA }\end{array}$ & $\begin{array}{l}\text { REMOTE } \\
\text { REMOTE } \\
\text { TOP - } 0.3 \\
\text { TOP }-0.3\end{array}$ \\
\hline 6 & $\begin{array}{l}\text { Complete a radiation survey IXM } \\
\text { and decontaminate, as needed }\end{array}$ & 20 & $\begin{array}{l}1 \text { PIC } \\
1 \text { operator } \\
1 \text { HPT }\end{array}$ & $\begin{array}{c}\text { SB } \\
\text { SB } \\
\text { STA }\end{array}$ & $\begin{array}{l}\text { REMOTE } \\
\text { REMOTE } \\
\text { SIDE }-0.3\end{array}$ \\
\hline 7 & $\begin{array}{l}\text { Attach rigging to IXM; move to a } \\
\text { temporary storage area }\end{array}$ & 30 & $\begin{array}{l}1 \text { PIC } \\
1 \text { operator } \\
1 \text { HPT } \\
2 \text { riggers }\end{array}$ & $\begin{array}{c}\text { SB } \\
\text { SB } \\
\text { SB } \\
\text { STA }\end{array}$ & $\begin{array}{l}\text { REMOTE } \\
\text { REMOTE } \\
\text { REMOTE } \\
\text { TOP }-0.3\end{array}$ \\
\hline 8 & $\begin{array}{l}\text { Complete a radiation survey IXM } \\
\text { and decontaminate, as needed }\end{array}$ & 10 & $\begin{array}{l}1 \text { PIC } \\
1 \text { operator } \\
1 \text { HPT }\end{array}$ & $\begin{array}{c}\text { SB } \\
\text { SB } \\
\text { STA }\end{array}$ & $\begin{array}{l}\text { REMOTE } \\
\text { REMOTE } \\
\text { SIDE - } 0.3\end{array}$ \\
\hline 9 & Move new IXM into position & 20 & $\begin{array}{l}\text { I PIC } \\
1 \text { operator } \\
1 \text { HPT } \\
2 \text { riggers }\end{array}$ & $\begin{array}{c}\text { SB } \\
\text { SB } \\
\text { STA } \\
\text { STA }\end{array}$ & $\begin{array}{l}\text { REMOTE } \\
\text { REMOTE } \\
\text { REMOTE } \\
\text { SIDE }-0.3\end{array}$ \\
\hline 10 & $\begin{array}{l}\text { Attach rigging to old IXM, move to } \\
\text { trailer and tie down }\end{array}$ & 30 & $\begin{array}{l}1 \mathrm{PIC} \\
1 \text { operator } \\
1 \mathrm{HPT} \\
2 \text { riggers }\end{array}$ & $\begin{array}{c}\text { SB } \\
\text { SB } \\
\text { SB } \\
\text { STA }\end{array}$ & $\begin{array}{l}\text { REMOTE } \\
\text { REMOTE } \\
\text { REMOTE } \\
\text { TOP - } 0.3\end{array}$ \\
\hline 11 & $\begin{array}{l}\text { Attach tractor to trailer and remove } \\
\text { from transfer area }\end{array}$ & 10 & $\begin{array}{l}1 \text { PIC } \\
1 \text { operator } \\
1 \text { HPT }\end{array}$ & $\begin{array}{l}\text { SB } \\
\text { SB } \\
\text { SB }\end{array}$ & $\begin{array}{l}\text { REMOTE } \\
\text { REMOTE } \\
\text { REMOTE }\end{array}$ \\
\hline 12 & $\begin{array}{l}\text { Prepare work area for installing new } \\
\text { IXM }\end{array}$ & 10 & $\begin{array}{l}1 \mathrm{PIC} \\
1 \text { operator } \\
1 \mathrm{HPT}\end{array}$ & $\begin{array}{c}\text { SB } \\
\text { STA } \\
\text { SB }\end{array}$ & $\begin{array}{l}\text { REMOTE } \\
\text { REMOTE } \\
\text { REMOTE }\end{array}$ \\
\hline 13 & $\begin{array}{l}\text { Remove plug; connect pipe and hose } \\
\text { to new inlet }\end{array}$ & 10 & $\begin{array}{l}1 \text { PIC } \\
1 \text { operator } \\
1 \text { HPT } \\
2 \text { pipefitters }\end{array}$ & $\begin{array}{l}\text { SB } \\
\text { STA } \\
\text { STA } \\
\text { STA }\end{array}$ & $\begin{array}{l}\text { REMOTE } \\
\text { REMOTE } \\
\text { REMOTE } \\
\text { REMOTE }\end{array}$ \\
\hline
\end{tabular}


Table 4-7. Manpower Estimates and Dose Rates for an Integrated Water Treatment System Ion Exchange Module Changeout. (2 sheets)

\begin{tabular}{|c|c|c|c|c|c|}
\hline Step & Description & $\begin{array}{l}\text { Duration } \\
\text { (min) }\end{array}$ & Personnel & $\begin{array}{l}\text { Background } \\
\text { Dose } \\
\text { Location }^{\mathrm{a}}\end{array}$ & $\begin{array}{l}\text { Location and } \\
\text { Distance }(m) \text { ) } \\
\text { from } \text { IXM }^{\mathrm{b}}\end{array}$ \\
\hline 14 & $\begin{array}{l}\text { Remove plug, connect pipe and hose } \\
\text { to new outlet. }\end{array}$ & 20 & $\begin{array}{l}\text { I PIC } \\
1 \text { operator } \\
1 \text { HPT } \\
2 \text { pipefitters }\end{array}$ & $\begin{array}{c}\text { SB } \\
\text { STA } \\
\text { STA } \\
\text { STA }\end{array}$ & $\begin{array}{l}\text { REMOTE } \\
\text { REMOTE } \\
\text { REMOTE } \\
\text { REMOTE }\end{array}$ \\
\hline 15 & Connect vent tree to top of IXM & 15 & $\begin{array}{l}1 \text { PIC } \\
1 \text { operator } \\
1 \text { HPT } \\
2 \text { pipefitters }\end{array}$ & $\begin{array}{l}\text { SB } \\
\text { STA } \\
\text { STA } \\
\text { STA }\end{array}$ & $\begin{array}{l}\text { REMOTE } \\
\text { REMOTE } \\
\text { REMOTE } \\
\text { REMOTE }\end{array}$ \\
\hline 16 & $\begin{array}{l}\text { Radiation survey of area and } \\
\text { decontamination }\end{array}$ & 10 & $\begin{array}{l}\text { PIC } \\
1 \text { operator }\end{array}$ & $\begin{array}{c}\text { SB } \\
\text { STA }\end{array}$ & $\begin{array}{l}\text { REMOTE } \\
\text { REMOTE }\end{array}$ \\
\hline 17 & Fill and vent new IXM & 35 & $\begin{array}{l}1 \text { PIC } \\
1 \text { operator }\end{array}$ & $\begin{array}{c}\text { SB } \\
\text { STA }\end{array}$ & $\begin{array}{l}\text { REMOTE } \\
\text { REMOTE }\end{array}$ \\
\hline
\end{tabular}

${ }^{2}$ See Table 4-1 for the definitions of the background dose location designators.

${ }^{b}$ See Table 4-6 for the definitions of the designators giving the location of personnel relative to the loaded IXM.

$\mathrm{HPT}=$ health physics technician.

IXM $=$ ion exchange module.

PIC $=$ person-in-charge.

The filter purge process is described briefly in Section 3.3.2.3. In most cases, the process is conducted remotely with no dose received by IWTS personnel. However, air scrubbing may occasionally be required. This technique requires an operator to manually connect and valve in an air supply to the filter vessel. The dose rate an operator is exposed to during this activity is estimated to be $1.5 \mathrm{mrem} / \mathrm{h}$ (Bullock 1999b) plus a background of $0.017 \mathrm{mrem} / \mathrm{h}$. The frequency that air scrubbing will be required is not known, but is expected to be less than once a month. To be conservative, a frequency of once per month was assumed.

The personnel dose resulting from IWTS- related activities at the K West Basin is dominated by the dose received during removal and replacement of the IWTS IXMs. It is expected that nearly one IXM will be replaced per week during ITWS operation and will involve at least seven workers, with up to five workers in a radiation zone at any one time. The manpower estimates and dose rates (Bullock 1999b) listed in Table 4-7 were based on previous experience with similar IXMs at the K Basins. 
SNF-4977 REV 0

This page intentionally left blank. 


\subsection{RESULTS}

Personnel doses resulting from FRS operations are listed in Table 5-1. Two operators were assumed to be involved in every activity. Since their roles in the operations are not fixed, only their combined doses are listed in Table 5-1. The spreadsheets used to compute the doses are presented in Appendix A. The total annual personnel dose is $7.9 \mathrm{rem}$, and the project lifetime dose from operations is $17.4 \mathrm{rem}$. Approximately $90 \%$ of these totals are from operations at the $\mathrm{K}$ East Basin. As previously stated, the project doses listed do not include those incurred during the equipment installation phase and the decontamination and equipment removal phase. Maintenance doses also are not included, but they are expected to be minor compared to the operation doses.

Table 5-1. Personnel Exposures from Fuel Retrieval Operations.

\begin{tabular}{|l|l|r|r|r|r|}
\hline Basin & \multicolumn{1}{|c|}{ Dose Units } & \multicolumn{1}{c|}{ PIC } & \multicolumn{1}{c|}{ HPT } & Operators $^{\mathbf{a}}$ & \multicolumn{1}{c|}{ Total } \\
\hline $\mathrm{KE}$ & $\mathrm{mrem} / \mathrm{MCO}$ & 12.0 & 6.0 & 52.8 & 70.8 \\
& $\mathrm{mrem} / \mathrm{yr}^{\mathrm{b}}$ & 1,200 & 600 & 5,280 & 7,080 \\
& $\mathrm{mrem} \mathrm{total}^{\mathrm{c}}$ & 2,640 & 1,320 & 11,600 & 15,600 \\
\hline $\mathrm{KW}$ & $\mathrm{mrem} / \mathrm{MCO}$ & 0.75 & 0.38 & 7.08 & 8.21 \\
& $\mathrm{mrem} / \mathrm{yr}^{\mathrm{b}}$ & 75 & 38 & 708 & 821 \\
& mrem total $^{\mathrm{c}}$ & 165 & 83 & 1,560 & 1,810 \\
\hline $\mathrm{KE}+\mathrm{KW}$ & $\mathrm{mrem}^{\mathrm{y}} \mathrm{yr}^{\mathrm{b}}$ & 1,280 & 638 & 5,990 & 7,900 \\
& mrem total $^{\mathrm{c}}$ & 2,810 & 1,400 & 13,200 & 17,400 \\
\hline
\end{tabular}

${ }^{2}$ Two operators were assumed to be involved in all fuel recovery system activities, as listed is Table 4-2.

${ }^{b}$ Annual doses (mrem/yr) were computed assuming that $100 \mathrm{MCOs}$ will be loaded per year in each basin (200 total per year).

${ }^{c}$ Total project doses were computed assuming that a total of $220 \mathrm{MCOs}$ will be loaded in each basin (440 total).

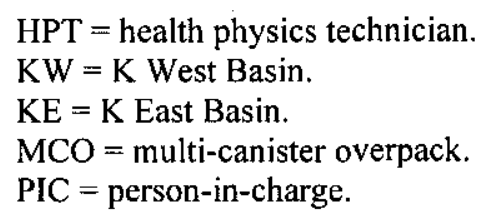

Personnel doses resulting from CLS operations are listed in Table 5-2. Two operators were assumed to be involved in most, but not all activities (see Table 4-4). As above, only the total doses for both operators are listed in Table 5-2. The spreadsheets used to compute the CLS personnel doses are presented in Appendix B. The total annual personnel dose is $37.4 \mathrm{rem}$, and the project lifetime dose from operations is $82.3 \mathrm{rem}$. Again, the doses do not include those incurred during the equipment installation, maintenance, and removal. However, maintenance doses are expected to be minor compared to the operation doses. 
Table 5-2. Personnel Exposures from Canister Loading System Operations.

\begin{tabular}{|c|c|c|c|c|c|c|}
\hline Basin & Dose Units & PIC & HPT & Operators ${ }^{\mathrm{a}}$ & $\begin{array}{l}\text { Truck } \\
\text { Driver }\end{array}$ & Total \\
\hline $\mathrm{KE}$ & $\begin{array}{l}\mathrm{mrem} / \mathrm{MCO} \\
\mathrm{mrem} / \mathrm{yr}^{\mathrm{b}} \\
\text { mrem total }\end{array}$ & $\begin{array}{r}4.0 \\
400 \\
880\end{array}$ & $\begin{array}{r}73.8 \\
7,380 \\
16,200\end{array}$ & $\begin{array}{r}152 \\
15,200 \\
33,400\end{array}$ & $\begin{array}{r}3.7 \\
370 \\
814\end{array}$ & $\begin{array}{r}234 \\
23,400 \\
51,300\end{array}$ \\
\hline KW & $\begin{array}{l}\mathrm{mrem} / \mathrm{MCO} \\
\mathrm{mrem} / \mathrm{yr}^{\mathrm{b}} \\
\mathrm{mrem} \text { total }^{\mathrm{c}}\end{array}$ & $\begin{array}{r}0.25 \\
25 \\
55\end{array}$ & $\begin{array}{r}47.5 \\
4,750 \\
10,500\end{array}$ & $\begin{array}{r}90 \\
9,000 \\
19,800\end{array}$ & $\begin{array}{r}2.8 \\
280 \\
616\end{array}$ & $\begin{array}{r}141 \\
14,100 \\
31,000\end{array}$ \\
\hline $\mathrm{KE}+\mathrm{KW}$ & $\begin{array}{l}\mathrm{mrem} / \mathrm{yr}^{\mathrm{b}} \\
\mathrm{mrem} \text { total }\end{array}$ & $\begin{array}{l}425 \\
935\end{array}$ & $\begin{array}{l}12,100 \\
26,700\end{array}$ & $\begin{array}{l}24,200 \\
53,200\end{array}$ & $\begin{array}{r}650 \\
1,430\end{array}$ & $\begin{array}{l}37,400 \\
82,300\end{array}$ \\
\hline
\end{tabular}

${ }^{a}$ Two operators were assumed to be involved in most cask loading system activities, as listed in Table 4-4.

${ }^{\mathrm{b}}$ Annual doses (mrem/yr) were computed assuming that $200 \mathrm{MCO}$ will be loaded per year (100 in each basin). basin).

${ }^{c}$ Total project doses were computed assuming that a total of $440 \mathrm{MCO}$ will be loaded (220 in each

$$
\begin{aligned}
& \mathrm{HPT}=\text { health physics technician. } \\
& \mathrm{KW}=\mathrm{K} \text { West Basin. } \\
& \mathrm{KE}=\mathrm{K} \text { East Basin. } \\
& \mathrm{MCO}=\text { multi-canister overpack. } \\
& \mathrm{PIC}=\text { person-in-charge. }
\end{aligned}
$$

Personnel doses resulting from the $\mathrm{K}$ West Basin IWTS operations and inspections are listed in Table 5-3. The replacement IXMs was assumed to require a PIC, an HPT, an operator, two riggers, and two pipefitters (see Table 4-7). The total doses for both riggers and both pipefitters are listed in Table 5-3. Sample collection involves an operator and an HPT, while the other IWTS activities require only an operator (see Table 4-6). The spreadsheets used to compute the IWTS personnel doses are presented in Appendix C. The total annual personnel dose is $3.03 \mathrm{rem}$, and the project lifetime dose from operations is $6.67 \mathrm{rem}$. These doses are for the K West Basin IWTS only and do not include doses incurred during the equipment installation, repair, and removal. No data are tabulated for the K East Basin IWTS, which is currently being designed. However, assuming that the manpower requirements for operations are similar to those for the K West Basin IWTS, doses for the K East Basin IWTS can be estimated by using the $\mathrm{K}$ East Basin background dose rates instead of $\mathrm{K}$ West background dose rates in the spreadsheet listed in Appendix C. Thus, the annual and project lifetime doses for the K East Basin IWTS might be about 3.87 rem and 8.50 rem, respectively. 
Table 5-3. Personnel Exposures from $\mathrm{K}$ West Basin Integrated Water Treatment System Operations.

\begin{tabular}{|l|c|c|c|c|c|c|}
\hline Dose Units & PIC & HPT & Operators & Riggers $^{\mathbf{a}}$ & Pipefitters $^{\mathbf{a}}$ & Total $^{\mathrm{b}}$ \\
\hline $\mathrm{Mrem}^{\mathrm{br}}{ }^{\mathrm{b}}$ & 2.2 & 1,040 & 767 & 486 & 732 & 3,030 \\
\hline $\mathrm{Mrem} \mathrm{total}^{\mathrm{c}}$ & 4.9 & 2,290 & 1,600 & 1,070 & 1,610 & 6,670 \\
\hline
\end{tabular}

${ }^{2}$ Two riggers and two pipefitters are involved in each IWTS ion exchange module changeout, as listed is Table 4-7. Doses listed are the total for each craft.

${ }^{\mathrm{b}}$ Annual doses (mrem/yr) were computed assuming there are 250 working days per year.

${ }^{\mathrm{c}}$ Total project doses were computed assuming $2.2 \mathrm{yr}$ of operation.

HPT $=$ health physics technician.

IWTS $=$ integrated water treatment system.

PIC $=$ person-in-charge. 


\section{SNF-4977 REV 0}

This page intentionally left blank. 


\subsection{CONCLUSION}

Section 5.0 contains tabulations of radiation doses that workers are expected to receive while carrying out routine FRS, CLS, and IWTS operations. The combined dose for all three operations in K West Basin is estimated to be $18.0 \mathrm{rem} / \mathrm{yr}$ or $39.6 \mathrm{rem}$ over the operational lifetime. The combined dose in K East Basin is estimated to be $34.4 \mathrm{rem} / \mathrm{yr}$ or $75.4 \mathrm{rem}$ lifetime. The combined $\mathrm{K}$ West and $\mathrm{K}$ East doses are then $52.4 \mathrm{rem} / \mathrm{yr}$ or $115 \mathrm{rem}$ lifetime. These doses were evaluated using current system designs, process flow information, operation sequences, manpower estimates, and measured or computed dose rates. Doses for the K East Basin IWTS assume that it will be designed and operated like the K West Basin IWTS. The personnel doses and the information on which they were based can be used for planning operations and staffing to keep facility and individual exposures ALARA and within applicable limits. 
SNF-4977 REV 0

This page intentionally left blank. 


\subsection{REFERENCES}

Bullock, D. E., 1999a, KE and KW Spreadsheets (electronic mail to J. V. Nelson, July 16), Fluor Daniel Hanford, Incorporated, Richland, Washington.

Bullock, D. E., 1999b, Ion Exchange Module Replacement Spreadsheet (electronic mail to J. V. Nelson, August 26), Fluor Daniel Hanford, Incorporated, Richland, Washington.

FDI, 1998, SNF Canister Storage Building ALARA Analysis 09, Fluor Daniel, Inc., under Contract 80460210, Richland, Washington.

HNF-2032, 1998, SNF Fuel Retrieval Subproject Safety Analysis Document, Rev. 0, DE\&S Hanford, Inc., for Fluor Daniel Hanford, Incorporated, Richland, Washington.

HNF-2456, 1999, Cask Loadout System Safety Analysis Document, Rev. 0, DE\&S Hanford, Inc., for Fluor Daniel Hanford, Incorporated, Richland, Washington.

HNF-SD-SNF-CN-026, 1997, MCO Shield Plug Dose Rate Analysis, Rev. 0, Fluor Daniel Northwest, Inc., for Fluor Daniel Hanford, Incorporated, Richland, Washington.

HNF-SD-SNF-FDR-003, 1997, Design Analysis Report for the TN-WHC Cask and Transportation System, Rev. 0, prepared by DE\&S Hanford, Inc. for Fluor Daniel Hanford, Incorporated, Richland, Washington.

HNF-SD-SNF-OCD-001, 1998, Spent Nuclear Fuel Project Product Specification, Rev. 2, prepared by Cogema for Fluor Daniel Hanford, Incorporated, Richland, Washington.

HNF-SD-SNF-OMM-003, 1997, TN-WHC Cask and Transportation System, Installation, Operation, Repair and Maintenance (IORM), Rev. 0, prepared by DE\&S Hanford, Inc. for Fluor Daniel Hanford, Incorporated, Richland, Washington.

HNF-SD-SNF-SAD-002, 1998, K West Basin Integrated Water Treatment System Subproject Safety Analysis Document, Rev. 2, Fluor Daniel Hanford, Incorporated, Richland, Washington.

Kensicki, S., "ALARA Report," attachment to letter to J. E. Loomis, Transmittal of K West Basin Integrated Water Treatment System Design, dated August 29, 1997, EDT No. 621526, Chem-Nuclear Systems, Inc., Columbia, South Carolina.

WHC-SD-WM-SAR-062, 1998, K Basins Safety Analysis Report, Rev. 3B, Fluor Daniel Hanford, Incorporated, Richland, Washington. 


\section{SNF-4977 REV 0}

This page intentionally left blank. 
SNF-4977 REV 0

APPENDIX A

COMPUTATION OF PERSONNEL DOSES DURING FUEL RETRIEVAL SYSTEM OPERATIONS 
SNF-4977 REV 0

This page intentionally left blank. 


\section{APPENDIX A \\ COMPUTATION OF PERSONNEL DOSES DURING FUEL RETRIEVAL SYSTEM OPERATIONS}

Listed below are the spreadsheets (Bullock 1999) used to compute the fuel retrieval system doses (mrem/multi-canister overpack [MCO]) given in Table 5-1. The first spreadsheet (Table A-1) applies to the K East Basin, while the second (Table A-2) applies to the K West Basin.

Dose computations in the spreadsheets are as follows:

$\{$ worker dose rate $\}=\{$ K Basin background $\}+\{$ background from $\mathrm{MCO}\}$

$\{$ dose-person $\}=\{$ no. of workers $\} *\{\text { worker dose rate }\}^{*}\{$ duration $\}$

A worker is either a person-in-charge (mgr in spreadsheets), an operator, or a health physics technician (HPT); dose rates are in $\mathrm{mrem} / \mathrm{h}$; duration is in $\mathrm{h}$; operator doses (dose-person in spreadsheets) are in mrem/canister or mrem/basket; and mgr and HPT doses are in $\mathrm{mrem} / \mathrm{MCO}$. The total dose for the two operators is computed as mrem/MCO using the equation:

$$
\mathrm{D}_{\mathrm{T}}=\sum_{\mathrm{i}} \mathrm{D}_{\mathrm{i}}^{*} \mathrm{~F}_{1}
$$

where

$\mathrm{D}_{\mathrm{T}}=$ total operator dose $(\mathrm{mrem} / \mathrm{MCO})$

$D_{i}=$ operator dose for activity $\mathrm{i}(\mathrm{mrem} /$ canister or mrem/basket)

$F_{i}=$ average number of canisters/MCO (19) or average number of baskets/MCO (5.3), whichever applies to step i.

Steps 1.01 through 2.14 in Table 3-1 apply to canisters; while steps 2.15 and 3.01 through 3.07 apply to baskets.

\section{REFERENCE}

Bullock, D. E., 1999, KE and KW Spreadsheets (electronic mail to J. V. Nelson, July 16), Fluor Daniel Hanford Incorporated, Richland, Washington. 
Table A-1. K East Basin Fuel Retrieval System Personnel Doses. (sheet 1 of 6 )

\begin{tabular}{|c|c|c|c|c|c|c|c|}
\hline $\begin{array}{l}\text { Prepare fuel for loading into } \\
\text { MCO }\end{array}$ & $\begin{array}{c}\text { Routine HPT } \\
\text { survey }\end{array}$ & $\begin{array}{c}\text { Routine PIC } \\
\text { observing }\end{array}$ & $\begin{array}{l}\text { Get next } \\
\text { canister } \\
\text { location }\end{array}$ & $\begin{array}{c}\text { Move } \\
\text { under- } \\
\text { water light }\end{array}$ & $\begin{array}{l}\text { Locate } \\
\text { canister }\end{array}$ & $\begin{array}{l}\text { Verify } \\
\text { canister } \\
\text { location }\end{array}$ & $\begin{array}{l}\text { Get offset } \\
\text { hook }(50 \% \\
\text { of canisters })\end{array}$ \\
\hline Location & Basin & Basin & Lifts Cans & Lifts Cans & Lifts Cans & Lifts Cans & Lifts Cans \\
\hline Background $\mathrm{mr} / \mathrm{hr}$ & 2.00 & 2.00 & 2.00 & 2.00 & 2.00 & 2.00 & 2.00 \\
\hline Background from $\mathrm{MCO}$ & 0.05 & $0 . \overline{05}$ & 0.05 & 0.05 & 0.05 & 0.05 & 0.05 \\
\hline Duration: Minutes/day & 180 & 360 & 1 & 1 & 1 & 0.5 & 1 \\
\hline Duration: Hours/day & 3 & 6 & 0.017 & 0.017 & 0.017 & 0.008 & 0.017 \\
\hline & & & \multicolumn{5}{|c|}{ Locate and move canister to washing station staging area } \\
\hline Average canisters per $\mathrm{MCO}$ & & & 19 & & & & \\
\hline $\begin{array}{l}\text { Average fuel baskets per } \\
\text { MCO }\end{array}$ & & & 5.3 & & & & \\
\hline \multicolumn{8}{|l|}{ Personnel: } \\
\hline \multicolumn{8}{|l|}{ Crane Operator } \\
\hline \multicolumn{8}{|l|}{ Dose Rate-mrem/hr } \\
\hline \multicolumn{8}{|l|}{ Dose-person-mrem } \\
\hline Operator (fuel retrieval) & & & 2 & 2 & 2 & 2 & 2 \\
\hline Dose Rate-mrem/hr & & & 2.05 & 2.05 & 2.05 & 2.05 & 2.05 \\
\hline Dose-person-mrem & & & 0.07 & 0.07 & 0.07 & 0.03 & 0.07 \\
\hline Mgr & & 1 & & & & & \\
\hline Dose Rate-mrem $/ \mathrm{hr}$ & & 2.00 & & & & & \\
\hline Dose-person-mrem & & 12.00 & & & & & \\
\hline $\mathrm{HPT}$ & 1 & & & & & & \\
\hline Dose Rate-mrem/hr & 2.00 & & & & & & \\
\hline Dose-person-mrem & 6.00 & & & & & & \\
\hline \multicolumn{8}{|l|}{ Truck Driver } \\
\hline \multicolumn{8}{|l|}{ Dose Rate-mrem/hr } \\
\hline \multicolumn{8}{|l|}{ Dose-person-mrem } \\
\hline \multicolumn{8}{|l|}{ Totals: } \\
\hline \multicolumn{8}{|l|}{ Crane Operator } \\
\hline Operator (fuel retrieval) & & & 0.07 & 0.07 & $0 . \overline{07}$ & 0.03 & 0.07 \\
\hline Mgr & & 12.00 & & & & & \\
\hline HPT & 6.00 & & & & & & \\
\hline \multicolumn{8}{|l|}{ Truck Driver } \\
\hline $\begin{array}{l}\text { Step totals per can or } \\
\text { basket }\end{array}$ & 6.00 & 12.00 & 0.07 & 0.07 & 0.07 & 0.03 & 0.07 \\
\hline Step totals per MCO & 6.00 & 12.00 & 1.30 & 1.30 & 1.30 & 0.65 & 1.30 \\
\hline
\end{tabular}


Table A-1. K East Basin Fuel Retrieval System Personnel Doses. (sheet 2 of 6)

\begin{tabular}{|c|c|c|c|c|c|c|c|}
\hline $\begin{array}{l}\text { Prepare fuel for loading } \\
\text { into } \mathrm{MCO}\end{array}$ & $\begin{array}{l}\text { Identify } \\
\text { receiving } \\
\text { inline } \\
\text { canister } \\
\text { location } \\
(50 \% \text { of } \\
\text { canisters })\end{array}$ & $\begin{array}{c}\text { Pick up } \\
\text { canister with } \\
\text { offset ( } 50 \% \\
\text { of canisters) }\end{array}$ & $\begin{array}{l}\text { Move to } \\
\text { inline row } \\
\text { ( } 50 \% \text { of } \\
\text { canisters) }\end{array}$ & $\begin{array}{c}\text { Set offset } \\
\text { aside }(50 \% \\
\text { of canisters) }\end{array}$ & $\begin{array}{c}\text { Get hoist and } \\
\text { stiffback }\end{array}$ & $\begin{array}{l}\text { Pick up } \\
\text { canister }\end{array}$ & $\begin{array}{l}\text { Move } \\
\text { canister } \\
\text { north to } \\
\text { north wall }\end{array}$ \\
\hline Location & Lifts Cans & Lifts Cans & Lifts Cans & Lifts Cans & Lifts Cans & Lifts Cans & Move Cans \\
\hline Background $\mathrm{mr} / \mathrm{hr}$ & 2.00 & 2.00 & 2.00 & 2.00 & 2.00 & 2.00 & 2.00 \\
\hline Background from MCO & 0.05 & 0.05 & 0.05 & 0.05 & 0.05 & 0.05 & 0.05 \\
\hline Duration: Minutes/day & 0.25 & 0.5 & 0.25 & 0.2 & 1 & 0.75 & 1.25 \\
\hline Duration: Hours/day & 0.004 & 0.008 & 0.004 & 0.003 & 0.017 & 0.013 & 0.021 \\
\hline & \multicolumn{7}{|c|}{ Locate and move canister to washing station staging area (continued) } \\
\hline \multicolumn{8}{|l|}{ Average canisters per $\mathrm{MCO}$} \\
\hline \multicolumn{8}{|l|}{$\begin{array}{l}\text { Average fuel baskets per } \\
\mathrm{MCO}\end{array}$} \\
\hline \multicolumn{8}{|l|}{ Personnel: } \\
\hline \multicolumn{8}{|l|}{ Crane Operator } \\
\hline \multicolumn{8}{|l|}{ Dose Rate-mrem/hr } \\
\hline \multicolumn{8}{|l|}{ Dose-person-mrem } \\
\hline Operator (fuel retrieval) & 2 & 2 & 2 & 2 & 2 & 2 & 2 \\
\hline Dose Rate-mrem/hr & 2.05 & 2.05 & 2.05 & 2.05 & 2.05 & 2.05 & 2.05 \\
\hline Dose-person-mrem & 0.02 & 0.03 & 0.02 & 0.01 & 0.07 & 0.05 & 0.09 \\
\hline \multicolumn{8}{|l|}{$\mathrm{Mgr}$} \\
\hline \multicolumn{8}{|l|}{ Dose Rate-mrem $/ \mathrm{hr}$} \\
\hline \multicolumn{8}{|l|}{ Dose-person-mrem } \\
\hline \multicolumn{8}{|l|}{$\mathrm{HPT}$} \\
\hline \multicolumn{8}{|l|}{ Dose Rate-mrem $/ \mathrm{hr}$} \\
\hline \multicolumn{8}{|l|}{ Dose-person-mrem } \\
\hline \multicolumn{8}{|l|}{ Truck Driver } \\
\hline \multicolumn{8}{|l|}{ Dose Rate-mrem $/ \mathrm{hr}$} \\
\hline \multicolumn{8}{|l|}{ Dose-person-mrem } \\
\hline \multicolumn{8}{|l|}{ Totals: } \\
\hline \multicolumn{8}{|l|}{ Crane Operator } \\
\hline Operator (fuel retrieval) & 0.02 & 0.03 & 0.02 & 0.01 & 0.07 & 0.05 & 0.09 \\
\hline \multicolumn{8}{|l|}{$\overline{\mathrm{Mgr}}$} \\
\hline \multicolumn{8}{|l|}{ HPT } \\
\hline \multicolumn{8}{|l|}{ Truck Driver } \\
\hline Step totals per can or basket & 0.02 & 0.03 & 0.02 & 0.01 & 0.07 & 0.05 & 0.09 \\
\hline Step totals per MCO & 0.32 & 0.65 & 0.32 & 0.26 & 1.30 & 0.97 & 1.62 \\
\hline
\end{tabular}


Table A-1. K East Basin Fuel Retrieval System Personnel Doses. (sheet 3 of 6)

\begin{tabular}{|c|c|c|c|c|c|c|c|}
\hline $\begin{array}{l}\text { Prepare fuel for loading } \\
\text { into } \mathrm{MCO}\end{array}$ & $\begin{array}{l}\text { Unlock rails } \\
\text { as needed }\end{array}$ & $\begin{array}{l}\text { Transfer } \\
\text { canister to } \\
\text { perimeter } \\
\text { trolley }\end{array}$ & $\begin{array}{c}\text { Move } \\
\text { canister to } \\
\text { north of } \\
\text { cleaning } \\
\text { staging area }\end{array}$ & $\begin{array}{c}\text { Unlock rails } \\
\text { as needed }\end{array}$ & $\begin{array}{l}\text { Transfer } \\
\text { canister to } \\
\text { rail north of } \\
\text { cleaning } \\
\text { staging area }\end{array}$ & $\begin{array}{l}\text { Set canister } \\
\text { down at } \\
\text { cleaning } \\
\text { staging area }\end{array}$ & $\begin{array}{c}\text { Sign } \\
\text { accountability } \\
\text { form }\end{array}$ \\
\hline Location & Lifts Cans & Move Cans & Move Cans & Lifts Cans & Move Cans & Move Cans & Move Cans \\
\hline Background $\mathrm{mr} / \mathrm{hr}$ & 2.00 & 2.00 & 2.00 & 2.00 & 2.00 & 1.80 & 1.80 \\
\hline Background from MCO & 0.05 & 0.05 & 0.05 & 0.05 & 0.05 & 0.05 & 0.05 \\
\hline Duration: Minutes/day & 0.25 & 0.25 & 2 & 0.25 & 0.25 & 0.75 & 0.5 \\
\hline \multirow[t]{2}{*}{ Duration: Hours/day } & 0.004 & 0.004 & 0.033 & 0.004 & 0.004 & 0.013 & 0,008 \\
\hline & \multicolumn{7}{|c|}{ Locate and move canister to washing station staging area (continued) } \\
\hline \multicolumn{8}{|l|}{ Average canisters per $\mathrm{MCO}$} \\
\hline \multicolumn{8}{|l|}{$\begin{array}{l}\text { Average fuel baskets per } \\
\mathrm{MCO}\end{array}$} \\
\hline \multicolumn{8}{|l|}{ Personnel: } \\
\hline \multicolumn{8}{|l|}{ Crane Operator } \\
\hline \multicolumn{8}{|l|}{ Dose Rate-mrem $/ \mathrm{hr}$} \\
\hline \multicolumn{8}{|l|}{ Dose-person-mrem } \\
\hline Operator (fuel retrieval) & 2 & 2 & 2 & 2 & 2 & 2 & 2 \\
\hline Dose Rate-mrem/hr & 2.05 & 2.05 & 2.05 & 2.05 & 2.05 & 1.85 & 1.85 \\
\hline Dose-person-mrem & 0.02 & 0.02 & 0.14 & 0.02 & 0.02 & 0.05 & 0.03 \\
\hline \multicolumn{8}{|l|}{$\mathrm{Mgr}$} \\
\hline \multicolumn{8}{|l|}{ Dose Rate-mrem/hr } \\
\hline \multicolumn{8}{|l|}{ Dose-person-mrem } \\
\hline \multicolumn{8}{|l|}{ HPT } \\
\hline \multicolumn{8}{|l|}{ Dose Rate-mrem $/ \mathrm{hr}$} \\
\hline \multicolumn{8}{|l|}{ Dose-person-mrem } \\
\hline \multicolumn{8}{|l|}{ Truck Driver } \\
\hline \multicolumn{8}{|l|}{ Dose Rate-mrem/hr } \\
\hline \multicolumn{8}{|l|}{ Dose-person-mrem } \\
\hline \multicolumn{8}{|l|}{ Totals: } \\
\hline & & & & & & & \\
\hline \multicolumn{8}{|l|}{ Crane Operator } \\
\hline Operator (fuel retrieval) & 0.02 & 0.02 & 0.14 & 0.02 & $0 . \overline{02}$ & 0.05 & 0.03 \\
\hline \multicolumn{8}{|l|}{$\mathrm{Mgr}$} \\
\hline \multicolumn{8}{|l|}{ HPT } \\
\hline \multicolumn{8}{|l|}{ Truck Driver } \\
\hline Step totals per can or basket & 0.02 & 0.02 & 0.14 & 0.02 & $0 . \overline{02}$ & 0.05 & 0.03 \\
\hline Step totals per MCO & 0.32 & 0.32 & 2.60 & 0.32 & 0.32 & 0.88 & 0.59 \\
\hline
\end{tabular}


Table A-1. K East Basin Fuel Retrieval System Personnel Doses. (sheet 4 of 6)

\begin{tabular}{|c|c|c|c|c|c|c|c|}
\hline $\begin{array}{l}\text { Prepare fuel for loading } \\
\text { into } \mathrm{MCO}\end{array}$ & $\begin{array}{c}\text { Pick up } \\
\text { empty } \\
\text { canister and } \\
\text { take to } \\
\text { staging area }\end{array}$ & $\begin{array}{c}\text { Take hoist to } \\
\text { next canister } \\
\text { location }\end{array}$ & $\begin{array}{l}\text { Pick up } \\
\text { staged } \\
\text { canister }\end{array}$ & $\begin{array}{c}\text { Put canister } \\
\text { in washing } \\
\text { machine }\end{array}$ & $\begin{array}{c}\text { Close lid and } \\
\text { wash }\end{array}$ & $\begin{array}{l}\text { Open lid and } \\
\text { remove } \\
\text { canister }\end{array}$ & $\begin{array}{l}\text { Close lid } \\
\text { and start } \\
\text { washing }\end{array}$ \\
\hline Location & Move MTs & Move Cans & Wash Fuel & Wash Fuel & Wash Fuel & Wash Fuel & Wash Fuel \\
\hline Background $\mathrm{mr} / \mathrm{hr}$ & 1.80 & 1.80 & 1.80 & 1.80 & 1.80 & 1.80 & 1.80 \\
\hline Background from $\mathrm{MCO}$ & 0.05 & 0.05 & 0.05 & 0.05 & 0.05 & 0.05 & 0.05 \\
\hline Duration: Minutes/day & 3.5 & 3.5 & 5 & 3 & 2 & 3 & 2 \\
\hline Duration: Hours/day & 0.058 & 0.058 & 0.083 & 0.050 & 0.033 & $0.0 \overline{50}$ & 0.033 \\
\hline & \multicolumn{2}{|c|}{ (Continued) } & \multicolumn{5}{|c|}{ Load washer, dump fuel onto inspection table and load fuel basket } \\
\hline \multicolumn{8}{|l|}{ Average canisters per $\mathrm{MCO}$} \\
\hline \multicolumn{8}{|l|}{$\begin{array}{l}\text { Average fuel baskets per } \\
\mathrm{MCO}\end{array}$} \\
\hline \multicolumn{8}{|l|}{ Personnel: } \\
\hline \multicolumn{8}{|l|}{ Crane Operator } \\
\hline \multicolumn{8}{|l|}{ Dose Rate-mrem/hr } \\
\hline \multicolumn{8}{|l|}{ Dose-person-mrem } \\
\hline Operator (fuel retrieval) & 2 & 2 & 1 & 1 & 1 & $\sqrt{1}$ & 1 \\
\hline Dose Rate-mrem/hr & 1.85 & 1.85 & 1.85 & 1.85 & 1.85 & 1.85 & 1.85 \\
\hline Dose-person-mrem & 0.22 & $0 . \overline{22}$ & 0.15 & 0.09 & 0.06 & 0.09 & 0.06 \\
\hline \multicolumn{8}{|l|}{$\mathrm{Mgr}$} \\
\hline \multicolumn{8}{|l|}{ Dose Rate-mrem $/ \mathrm{hr}$} \\
\hline \multicolumn{8}{|l|}{ Dose-person-mrem } \\
\hline \multicolumn{8}{|l|}{$\overline{\mathrm{HPT}}$} \\
\hline \multicolumn{8}{|l|}{ Dose Rate-mrem/hr } \\
\hline \multicolumn{8}{|l|}{ Dose-person-mrem } \\
\hline \multicolumn{8}{|l|}{ Truck Driver } \\
\hline \multicolumn{8}{|l|}{ Dose Rate-mrem $/ \mathrm{hr}$} \\
\hline \multicolumn{8}{|l|}{ Dose-person-mrem } \\
\hline \multicolumn{8}{|l|}{ Totals: } \\
\hline \multicolumn{7}{|l|}{ Crane Operator } & \\
\hline Operator (fuel retrieval) & 0.22 & 0.22 & 0.15 & 0.09 & 0.06 & 0.09 & 0.06 \\
\hline \multicolumn{8}{|l|}{$\mathrm{Mgr}$} \\
\hline \multicolumn{8}{|l|}{ HPT } \\
\hline \multicolumn{8}{|l|}{ Truck Driver } \\
\hline Step totals per can or basket & 0.22 & 0.22 & 0.15 & 0.09 & 0.06 & 0.09 & 0.06 \\
\hline Step totals per MCO & 4.10 & 4.10 & 2.93 & $1.7 \overline{6}$ & 1.17 & 1.76 & 1.17 \\
\hline
\end{tabular}


Table A-1. K East Basin Fuel Retrieval System Personnel Doses. (sheet 5 of 6)

\begin{tabular}{|c|c|c|c|c|c|c|c|}
\hline $\begin{array}{l}\text { Prepare fuel for loading } \\
\text { into MCO }\end{array}$ & $\begin{array}{l}\text { Verify } \\
\text { canister is } \\
\text { empty then } \\
\text { set aside }\end{array}$ & $\begin{array}{c}\text { Remove } \\
\text { stuck fuel in } \\
\text { can, as } \\
\text { needed. Put } \\
\text { fucl in } \\
\text { washer }\end{array}$ & $\begin{array}{l}\text { Open washer } \\
\text { lid and dump } \\
\text { cleaned fuel } \\
\text { onto table }\end{array}$ & $\begin{array}{c}\text { Separate fuel } \\
\text { elements }\end{array}$ & $\begin{array}{l}\text { Inspect } \\
\text { elements }\end{array}$ & $\begin{array}{c}\text { Second } \\
\text { Cleaning of } \\
\text { fuel, as } \\
\text { needed }\end{array}$ & $\begin{array}{l}\text { Record new } \\
\text { fuel basket } \\
\text { number }\end{array}$ \\
\hline Location & Wash Fuel & Wash Fuel & Wash Fuel & Remote & Remote & Wash Fuel & Wash Fuel \\
\hline Background $\mathrm{mr} / \mathrm{hr}$ & 1.80 & 1.80 & 1.80 & & & 1.80 & 1.80 \\
\hline Background from $\mathrm{MCO}$ & 0.05 & 0.05 & 0.05 & & & 0.05 & 0.05 \\
\hline Duration: Minutes/day & 3 & 10 & 5 & 15 & 12 & 10 & 2 \\
\hline Duration: Hours/day & 0.050 & 0.167 & 0.083 & 0.250 & 0.200 & 0.167 & 0.033 \\
\hline & \multicolumn{7}{|c|}{ Load washer, dump fuel onto inspection table and load fuel basket (continued) } \\
\hline \multicolumn{8}{|l|}{ Average canisters per $\mathrm{MCO}$} \\
\hline \multicolumn{8}{|l|}{$\begin{array}{l}\text { Average fuel baskets per } \\
\mathrm{MCO}\end{array}$} \\
\hline \multicolumn{8}{|l|}{ Personnel: } \\
\hline \multicolumn{8}{|l|}{ Crane Operator } \\
\hline \multicolumn{8}{|l|}{ Dose Rate-mrem/hr } \\
\hline \multicolumn{8}{|l|}{ Dose-person-mrem } \\
\hline Operator (fuel retrieval) & 1 & 1 & 1 & 1 & 1 & 1 & 1 \\
\hline Dose Rate-mrem/hr & 1.85 & 1.85 & 1.85 & & & 1.85 & 1.85 \\
\hline Dose-person-mrem & 0.09 & 0.31 & 0.15 & & & 0.31 & 0.06 \\
\hline \multicolumn{8}{|l|}{ Mgr } \\
\hline \multicolumn{8}{|l|}{ Dose Rate-mrem/hr } \\
\hline \multicolumn{8}{|l|}{ Dose-person-mrem } \\
\hline \multicolumn{8}{|l|}{$\mathrm{HPT}$} \\
\hline \multicolumn{8}{|l|}{ Dose Rate-mrem/hr } \\
\hline \multicolumn{8}{|l|}{ Dose-person-mrem } \\
\hline \multicolumn{8}{|l|}{ Truck Driver } \\
\hline \multicolumn{8}{|l|}{ Dose Rate-mrem/hr } \\
\hline \multicolumn{8}{|l|}{ Dose-person-mrem } \\
\hline \multicolumn{8}{|l|}{ Totals: } \\
\hline \multicolumn{8}{|l|}{ Crane Operator } \\
\hline Operator (fuel retrieval) & 0.09 & 0.31 & 0.15 & & & 0.31 & 0.06 \\
\hline \multicolumn{8}{|l|}{$\mathrm{Mgr}$} \\
\hline \multicolumn{8}{|l|}{$\mathrm{HPT}$} \\
\hline \multicolumn{8}{|l|}{ Truck Driver } \\
\hline Step totals per can or basket & 0.09 & 0.31 & 0.15 & & & 0.31 & 0.06 \\
\hline Step totals per MCO & 1.76 & 5.86 & 2.93 & & & 5.86 & 0.33 \\
\hline
\end{tabular}


Table A-1. K East Basin Fuel Retrieval System Personnel Doses. (sheet 6 of 6 )

\begin{tabular}{|c|c|c|c|c|c|c|c|c|}
\hline $\begin{array}{l}\text { Prepare fuel for loading } \\
\text { into } \mathrm{MCO}\end{array}$ & $\begin{array}{c}\text { Load fuel } \\
\text { basket with } \\
\text { fuel }\end{array}$ & $\begin{array}{l}\text { Pick up full } \\
\text { fuel basket }\end{array}$ & $\begin{array}{c}\text { Weigh full } \\
\text { basket and } \\
\text { record }\end{array}$ & $\begin{array}{c}\text { Video full } \\
\text { fuel basket }\end{array}$ & $\begin{array}{l}\text { Move full } \\
\text { basket } \\
\text { south on } \\
\text { rail }\end{array}$ & $\begin{array}{c}\text { Transfer } \\
\text { full basket } \\
\text { to trolley. } \\
\text { Take to } \\
\text { MCO load } \\
\text { staging }\end{array}$ & $\begin{array}{l}\text { Pick up } \\
\text { empty } \\
\text { basket; } \\
\text { transfer to } \\
\text { inspection } \\
\text { table }\end{array}$ & $\begin{array}{l}\text { All Fuel } \\
\text { Operation } \\
\text { (Per MCO } \\
\text { Totals) }\end{array}$ \\
\hline Location & Remote & Wash Fuel & Wash Fuel & Wash Fuel & Move Bskt & Move Bskt & Move Bskt & \\
\hline Background $\mathrm{mr} / \mathrm{hr}$ & & 1.80 & 1.80 & 1.80 & 1.80 & 1.80 & 1.80 & \\
\hline Background from $\mathrm{MCO}$ & & 0.05 & 0.05 & 0.05 & 0.05 & 0.05 & 0.05 & \\
\hline Duration: Minutes/day & $5 \overline{40}$ & 1.5 & 2 & 1 & 0.5 & 5 & 5 & \\
\hline Duration: Hours/day & 9.000 & 0.025 & 0.033 & 0.017 & 0.008 & 0.083 & 0.083 & 86.69 \\
\hline & (continued) & \multicolumn{6}{|c|}{ Stage full fuel basket; bring in new empty } & \\
\hline \multicolumn{9}{|l|}{ Average canisters per $\mathrm{MCO}$} \\
\hline \multicolumn{9}{|l|}{$\begin{array}{l}\text { Average fuel baskets per } \\
\text { MCO }\end{array}$} \\
\hline \multicolumn{9}{|l|}{ Personnel: } \\
\hline \multicolumn{9}{|l|}{ Crane Operator } \\
\hline \multicolumn{9}{|l|}{ Dose Rate-mrem $/ \mathrm{hr}$} \\
\hline \multicolumn{9}{|l|}{ Dose-person-mrem } \\
\hline Operator (fuel retrieval) & 1 & 1 & 1 & 1 & 1 & 1 & 1 & \\
\hline Dose Rate-mrem $/ \mathrm{hr}$ & & 1.85 & 1.85 & 1.85 & 1.85 & 1.85 & 1.85 & \\
\hline Dose-person-mrem & & 0.05 & 0.06 & 0.03 & 0.02 & 0.15 & 0.15 & 52.83 \\
\hline \multicolumn{9}{|l|}{$\mathrm{Mgr}$} \\
\hline \multicolumn{9}{|l|}{ Dose Rate-mrem $/ \mathrm{hr}$} \\
\hline Dose-person-mrem & & & & & & & & 12.00 \\
\hline \multicolumn{9}{|l|}{$\mathrm{HPT}$} \\
\hline \multicolumn{9}{|l|}{ Dose Rate-mrem/hr } \\
\hline Dose-person-mrem & & & & & & & & 6.00 \\
\hline \multicolumn{9}{|l|}{ Truck Driver } \\
\hline \multicolumn{9}{|l|}{ Dose Rate-mrem $/ \mathrm{hr}$} \\
\hline \multicolumn{9}{|l|}{ Dose person-mrem } \\
\hline Totals: & & & & & & & & 70.83 \\
\hline \multicolumn{9}{|l|}{ Crane Operator } \\
\hline Operator (fuel retrieval) & & 0.05 & 0.06 & 0.03 & 0.02 & 0.15 & 0.15 & 52.83 \\
\hline Mgr & & & & & & & & 12.00 \\
\hline HPT & & & & & & & & 6.00 \\
\hline \multicolumn{9}{|l|}{ Truck Driver } \\
\hline Step totals per can or basket & & 0.05 & 0.06 & 0.03 & 0.02 & 0.15 & 0.15 & 70.83 \\
\hline
\end{tabular}


Table A-2. K West Basin Fuel Retrieval System Personnel Doses. (sheet 1 of 7)

\begin{tabular}{|c|c|c|c|c|c|c|c|}
\hline $\begin{array}{l}\text { Prepare fuel for loading into } \\
\text { MCO }\end{array}$ & $\begin{array}{c}\text { Routine } \\
\text { HPT survey }\end{array}$ & $\begin{array}{c}\text { Routine PIC } \\
\text { observing }\end{array}$ & $\begin{array}{l}\text { Get next } \\
\text { canister } \\
\text { location }\end{array}$ & $\begin{array}{c}\text { Move } \\
\text { under-water } \\
\text { light }\end{array}$ & $\begin{array}{l}\text { Locate } \\
\text { canister }\end{array}$ & $\begin{array}{l}\text { Verify } \\
\text { canister } \\
\text { location }\end{array}$ & $\begin{array}{c}\text { Get offset } \\
\text { hook }(50 \% \\
\text { of canisters) }\end{array}$ \\
\hline Location & Lifts Cans & Lifts Cans & Lifts Cans & Lifts Cans & Lifts Cans & Lifts Cans & Lifts Cans \\
\hline Background $\mathrm{mr} / \mathrm{hr}$ & 0.13 & 0.13 & 0.13 & $0 . \overline{13}$ & 0.13 & 0.13 & 0.13 \\
\hline Background from $\mathrm{MCO}$ & 0.05 & 0.05 & 0.05 & 0.05 & 0.05 & 0.05 & 0.05 \\
\hline Duration: Minutes/day & 180 & 360 & 1 & 1 & 1 & 0.5 & 1 \\
\hline Duration: Hours/day & 3 & 6 & 0.017 & 0.017 & 0.017 & 0.008 & 0.017 \\
\hline & & & \multicolumn{5}{|c|}{ Locate and move canister to washing station staging area } \\
\hline Average canisters per $\mathrm{MCO}$ & & & 19 & & & & \\
\hline $\begin{array}{l}\text { Average fuel baskets per } \\
\text { MCO }\end{array}$ & & & 5.3 & & & & \\
\hline \multicolumn{8}{|l|}{ Personnel: } \\
\hline \multicolumn{8}{|l|}{ Crane Operator } \\
\hline \multicolumn{8}{|l|}{ Dose Rate-mrem/hr } \\
\hline \multicolumn{8}{|l|}{ Dose-person-mrem } \\
\hline Operator (fuel retrieval) & & & 2 & 2 & 2 & 2 & 2 \\
\hline Dose Rate-mrem $/ \mathrm{hr}$ & & & 0.18 & 0.18 & 0.18 & 0.18 & 0.18 \\
\hline Dose-person-mrem & & & 0.01 & 0.01 & 0.01 & 0.00 & 0.01 \\
\hline Mgr & & 1 & & & & & \\
\hline Dose Rate-mrem/hr & & 0.13 & & & & & \\
\hline Dose-person-mrem & & 0.75 & & & & & \\
\hline $\mathrm{HPT}$ & 1 & & & & & & \\
\hline Dose Rate-mrem/hr & 0.13 & & & & & & \\
\hline Dose-person-mrem & 0.38 & & & & & & \\
\hline \multicolumn{8}{|l|}{ Truck Driver } \\
\hline \multicolumn{8}{|l|}{ Dose Rate-mrem/hr } \\
\hline \multicolumn{8}{|l|}{ Dose-person-mrem } \\
\hline \multicolumn{8}{|l|}{ Totals: } \\
\hline \multicolumn{8}{|l|}{ Crane Operator } \\
\hline Operator (fuel retrieval) & & & $0.0 \mathrm{~J}$ & 0.01 & 0.01 & 0.00 & 0.01 \\
\hline $\mathrm{Mgr}$ & & 0.75 & & & & & \\
\hline HPT & 0.38 & & & & & & \\
\hline \multicolumn{8}{|l|}{ Truck Driver } \\
\hline $\begin{array}{l}\text { Step totals per can or } \\
\text { basket }\end{array}$ & 0.38 & 0.75 & 0.01 & 0.01 & 0.01 & 0.00 & 0.01 \\
\hline Step totals per MCO & 0.38 & 0.75 & 0.11 & 0.11 & 0.11 & 0.06 & 0.11 \\
\hline
\end{tabular}


Table A-2. K East Basin Fuel Retrieval System Personnel Doses. (sheet 2 of 7)

\begin{tabular}{|c|c|c|c|c|c|c|c|}
\hline $\begin{array}{l}\text { Prepare fuel for loading into } \\
\text { MCO }\end{array}$ & $\begin{array}{c}\text { Identify } \\
\text { receiving } \\
\text { inline } \\
\text { canister } \\
\text { location } \\
\text { (50\% of } \\
\text { canisters) } \\
\end{array}$ & $\begin{array}{c}\text { Pick up } \\
\text { canister with } \\
\text { offset ( } 50 \% \\
\text { of canisters) }\end{array}$ & $\begin{array}{l}\text { Move to } \\
\text { inline row } \\
\text { (50\% of } \\
\text { canisters) }\end{array}$ & $\begin{array}{c}\text { Set offset } \\
\text { aside }(50 \% \\
\text { of canisters })\end{array}$ & $\begin{array}{c}\text { Get hoist and } \\
\text { stiffback }\end{array}$ & $\begin{array}{l}\text { Pick up } \\
\text { canister }\end{array}$ & $\begin{array}{c}\text { Move } \\
\text { canister } \\
\text { north to } \\
\text { north wall }\end{array}$ \\
\hline Location & Lifts Cans & Lifts Cans & Lifts Cans & Lifts Cans & Lifts Cans & Lifts Cans & Move Cans \\
\hline Background $\mathrm{mr} / \mathrm{hr}$ & 0.13 & 0.13 & 0.13 & 0.13 & 0.13 & 0.13 & 0.13 \\
\hline Background from $\mathrm{MCO}$ & 0.05 & 0.05 & 0.05 & 0.05 & 0.05 & 0.05 & 0.05 \\
\hline Duration: Minutes/day & 0.25 & 0.5 & 0.25 & 0.2 & 1 & 0.75 & 1.25 \\
\hline \multirow[t]{2}{*}{ Duration: Hours/day } & 0.004 & 0.008 & 0.004 & 0.003 & 0.017 & 0.013 & 0.021 \\
\hline & \multicolumn{7}{|c|}{ Locate and move canister to washing station staging area (continued) } \\
\hline \multicolumn{8}{|l|}{ Average canisters per $\mathrm{MCO}$} \\
\hline \multicolumn{8}{|l|}{$\begin{array}{l}\text { Average fuel baskets per } \\
\mathrm{MCO}\end{array}$} \\
\hline \multicolumn{8}{|l|}{ Personnel: } \\
\hline \multicolumn{8}{|l|}{ Crane Operator } \\
\hline \multicolumn{8}{|l|}{ Dose Rate-mrem/hr } \\
\hline \multicolumn{8}{|l|}{ Dose-person-mrem } \\
\hline Operator (fuel retrieval) & 2 & 2 & 2 & 2 & 2 & 2 & 2 \\
\hline Dose Rate-mrem $/ \mathrm{hr}$ & 0.18 & 0.18 & 0.18 & 0.18 & 0.18 & 0.18 & 0.18 \\
\hline Dose-person-mrem & 0.00 & 0.00 & 0.00 & 0.00 & 0.01 & 0.00 & 0.01 \\
\hline \multicolumn{8}{|l|}{$\mathrm{Mgr}$} \\
\hline \multicolumn{8}{|l|}{ Dose Rate-mrem/hr } \\
\hline \multicolumn{8}{|l|}{ Dose-person-mrem } \\
\hline \multicolumn{8}{|l|}{$\mathrm{HPT}$} \\
\hline \multicolumn{8}{|l|}{ Dose Rate-mrem $/ \mathrm{hr}$} \\
\hline \multicolumn{8}{|l|}{ Dose-person-mrem } \\
\hline \multicolumn{8}{|l|}{ Truck Driver } \\
\hline \multicolumn{8}{|l|}{ Dose Rate-mrem/hr } \\
\hline \multicolumn{8}{|l|}{ Dose-person-mrem } \\
\hline \multicolumn{8}{|l|}{ Totals: } \\
\hline \multicolumn{8}{|l|}{ Crane Operator } \\
\hline Operator (fuel retrieval) & 0.00 & 0.00 & 0.00 & 0.00 & 0.01 & 0.00 & 0.01 \\
\hline \multicolumn{8}{|l|}{$\mathrm{Mgr}$} \\
\hline \multicolumn{8}{|l|}{ HPT } \\
\hline \multicolumn{8}{|l|}{ Truck Driver } \\
\hline Step totals per can or basket & 0.00 & 0.00 & 0.00 & 0.00 & 0.01 & 0.00 & 0.01 \\
\hline Step totals per MCO & 0.03 & 0.06 & 0.03 & 0.02 & 0.11 & 0.08 & 0.14 \\
\hline
\end{tabular}


Table A-2. K West Basin Fuel Retrieval System Personnel Doses. (sheet 3 of 7)

\begin{tabular}{|c|c|c|c|c|c|c|c|}
\hline $\begin{array}{l}\text { Prepare fuel for loading into } \\
\text { MCO }\end{array}$ & $\begin{array}{c}\text { Unlock rails } \\
\text { as needed }\end{array}$ & $\begin{array}{l}\text { Transfer } \\
\text { canister to } \\
\text { perimeter } \\
\text { trolley }\end{array}$ & $\begin{array}{c}\text { Move } \\
\text { canister to } \\
\text { north of } \\
\text { cleaning } \\
\text { staging area }\end{array}$ & $\begin{array}{c}\text { Unlock rails } \\
\text { as needed }\end{array}$ & \begin{tabular}{|} 
Transfer \\
canister to \\
rail north of \\
cleaning \\
staging area
\end{tabular} & $\begin{array}{c}\text { Set canister } \\
\text { down at } \\
\text { cleaning } \\
\text { staging area }\end{array}$ & $\begin{array}{l}\text { Sign account } \\
\text { ability form }\end{array}$ \\
\hline Location & Lifts Cans & Move Cans & Move Cans & Lifts Cans & Move Cans & Move Cans & Move Cans \\
\hline Background mr/hr & 0.13 & 0.13 & 0.13 & 0.13 & 0.13 & 0.13 & 0.13 \\
\hline Background from $\mathrm{MCO}$ & 0.05 & 0.05 & 0.05 & 0.05 & 0.05 & 0.05 & 0.05 \\
\hline Duration: Minutes/day & 0.25 & 0.25 & 2 & 0.25 & 0.25 & 0.75 & 0.5 \\
\hline \multirow[t]{2}{*}{ Duration: Hours/day } & 0.004 & 0.004 & $\begin{array}{r}0.033 \\
\end{array}$ & $\begin{array}{r}0.004 \\
\end{array}$ & 0.004 & 0.013 & 0.008 \\
\hline & \multicolumn{7}{|c|}{ Locate and move canister to washing station staging area (continued) } \\
\hline \multicolumn{8}{|l|}{ Average canisters per MCO } \\
\hline \multicolumn{8}{|l|}{$\begin{array}{l}\text { Average fuel baskets per } \\
\text { MCO }\end{array}$} \\
\hline \multicolumn{8}{|l|}{ Personnel: } \\
\hline \multicolumn{8}{|l|}{ Crane Operator } \\
\hline \multicolumn{8}{|l|}{ Dose Rate-mrem/hr } \\
\hline \multicolumn{8}{|l|}{ Dose-person-mrem } \\
\hline Operator (fuel retrieval) & 2 & 2 & 2 & 2 & 2 & 2 & 2 \\
\hline Dose Rate-mrem/hr & 0.18 & 0.18 & 0.18 & 0.18 & 0.18 & 0.18 & 0.18 \\
\hline Dose-person-mrem & 0.00 & 0.00 & 0.01 & 0.00 & 0.00 & 0.00 & 0.00 \\
\hline \multicolumn{8}{|l|}{ Mgr } \\
\hline \multicolumn{8}{|l|}{ Dose Rate-mrem/hr } \\
\hline \multicolumn{8}{|l|}{ Dose-person-mrem } \\
\hline \multicolumn{8}{|l|}{ HPT } \\
\hline \multicolumn{8}{|l|}{ Dose Rate-mrem/hr } \\
\hline \multicolumn{8}{|l|}{ Dose-person-mrem } \\
\hline \multicolumn{8}{|l|}{ Truck Driver } \\
\hline \multicolumn{8}{|l|}{ Dose Rate-mrem/hr } \\
\hline \multicolumn{8}{|l|}{ Dose-person-mrem } \\
\hline \multicolumn{8}{|l|}{ Totals: } \\
\hline \multicolumn{8}{|l|}{ Crane Operator } \\
\hline Operator (fuel retrieval) & 0.00 & 0.00 & 0.01 & 0.00 & 0.00 & 0.00 & 0.00 \\
\hline \multicolumn{8}{|l|}{$\mathrm{Mgr}$} \\
\hline \multicolumn{8}{|l|}{$\mathrm{HPT}$} \\
\hline \multicolumn{8}{|l|}{ Truck Driver } \\
\hline Step totals per can or basket & 0.00 & 0.00 & 0.01 & 0.00 & 0.00 & 0.00 & 0.00 \\
\hline Step totals per $\mathrm{MCO}$ & 0.03 & 0.03 & 0.22 & 0.03 & 0.03 & 0.08 & 0.06 \\
\hline
\end{tabular}


Table A-2. K West Basin Fuel Retrieval System Personnel Doses (sheet 4 of 7)

\begin{tabular}{|c|c|c|c|c|c|c|c|}
\hline $\begin{array}{l}\text { Prepare fuel for loading into } \\
\text { MCO }\end{array}$ & $\begin{array}{c}\text { Pick up } \\
\text { empty } \\
\text { canister and } \\
\text { take to } \\
\text { staging area }\end{array}$ & $\begin{array}{c}\text { Take hoist to } \\
\text { next canister } \\
\text { location }\end{array}$ & $\begin{array}{l}\text { Pick up } \\
\text { staged } \\
\text { canister }\end{array}$ & $\begin{array}{c}\text { Put in } \\
\text { decapper; } \\
\text { degas, delid } \\
\text { and dewater }\end{array}$ & $\begin{array}{c}\text { Put lids in } \\
\text { debris basket }\end{array}$ & $\begin{array}{c}\text { Pick up } \\
\text { canister from } \\
\text { decapper }\end{array}$ & $\begin{array}{c}\text { Put canister } \\
\text { in washing } \\
\text { machine }\end{array}$ \\
\hline Location & Move MTs & Move Cans & Wash Fuel & Wash Fuel & Wash Fuel & Wash Fuel & Wash Fuel \\
\hline Background $\mathrm{mr} / \mathrm{hr}$ & 0.13 & 0.13 & 0.09 & 0.09 & 0.09 & 0.09 & 0.09 \\
\hline Background from $\mathrm{MCO}$ & 0.05 & 0.05 & 0.05 & 0.05 & 0.05 & 0.05 & $\overline{0.05}$ \\
\hline Duration: Minutes/day & 3.5 & 3.5 & 5 & 40 & 10 & 10 & 3 \\
\hline \multirow[t]{2}{*}{ Duration: Hours/day } & 0.058 & 0.058 & 0.083 & 0.667 & 0.167 & 0.167 & 0.050 \\
\hline & \multicolumn{2}{|c|}{ (continued) } & \multicolumn{5}{|c|}{ Load washer, dump fuel on to inspection table and load fuel basket } \\
\hline \multicolumn{8}{|l|}{ Average canisters per $\mathrm{MCO}$} \\
\hline \multicolumn{8}{|l|}{$\begin{array}{l}\text { Average fuel baskets per } \\
\mathrm{MCO}\end{array}$} \\
\hline \multicolumn{8}{|l|}{ Personnel: } \\
\hline \multicolumn{8}{|l|}{ Crane Operator } \\
\hline \multicolumn{8}{|l|}{ Dose Rate-mrem/hr } \\
\hline \multicolumn{8}{|l|}{ Dose-person-mrem } \\
\hline Operator (fuel retrieval) & 2 & 2 & 1 & 1 & 1 & 1 & 1 \\
\hline Dose Rate-mrem/hr & 0.18 & 0.18 & 0.14 & 0.14 & 0.14 & 0.14 & 0.14 \\
\hline Dose-person-mrem & 0.02 & 0.02 & 0.01 & 0.09 & 0.02 & 0.02 & 0.01 \\
\hline \multicolumn{8}{|l|}{$\mathrm{Mgr}$} \\
\hline \multicolumn{8}{|l|}{ Dose Rate-mrem $/ \mathrm{hr}$} \\
\hline \multicolumn{8}{|l|}{ Dose-person-mrem } \\
\hline \multicolumn{8}{|l|}{ HPT } \\
\hline \multicolumn{8}{|l|}{ Dose Rate-mrem/hr } \\
\hline \multicolumn{8}{|l|}{ Dose-person-mrem } \\
\hline \multicolumn{8}{|l|}{ Truck Driver } \\
\hline \multicolumn{8}{|l|}{ Dose Rate-mrem/hr } \\
\hline \multicolumn{8}{|l|}{ Dose-person-mrem } \\
\hline \multicolumn{8}{|l|}{ Totals: } \\
\hline \multicolumn{8}{|l|}{ Crane Operator } \\
\hline Operator (fuel retrieval) & 0.02 & 0.02 & 0.01 & 0.09 & 0.02 & 0.02 & 0.01 \\
\hline \multicolumn{8}{|l|}{$\mathrm{Mgr}$} \\
\hline \multicolumn{8}{|l|}{$\mathrm{HPT}$} \\
\hline \multicolumn{8}{|l|}{ Truck Driver } \\
\hline Step totals per can or basket & 0.02 & 0.02 & 0.01 & 0.09 & 0.02 & 0.02 & 0.01 \\
\hline Step totals per MCO & 0.39 & 0.39 & 0.22 & 1.77 & 0.44 & 0.44 & 0.13 \\
\hline
\end{tabular}


Table A-2. K West Basin Fuel Retrieval System Personnel Doses (sheet 5 of 7 )

\begin{tabular}{|c|c|c|c|c|c|c|c|}
\hline $\begin{array}{l}\text { Prepare fuel for loading into } \\
\text { MCO }\end{array}$ & $\begin{array}{c}\text { Close lid and } \\
\text { wash }\end{array}$ & $\begin{array}{c}\text { Open lid and } \\
\text { remove } \\
\text { canister }\end{array}$ & $\begin{array}{l}\text { Close lid and } \\
\text { start washing }\end{array}$ & $\begin{array}{l}\text { Vcrify } \\
\text { canister is } \\
\text { empty then } \\
\text { set aside }\end{array}$ & \begin{tabular}{|c|} 
Remove \\
stuck fuel in \\
can, as \\
needed. Put \\
fuel in \\
washer
\end{tabular} & $\begin{array}{c}\text { Open washer } \\
\text { lid and dump } \\
\text { cleaned fuel } \\
\text { onto table }\end{array}$ & $\begin{array}{c}\text { Separate fuel } \\
\text { elements }\end{array}$ \\
\hline Location & Wash Fuel & Wash Fuel & Wash Fuel & Wash Fuel & Wash Fuel & Wash Fuel & Remote \\
\hline Background $\mathrm{mr} / \mathrm{hr}$ & 0.09 & 0.09 & 0.09 & 0.09 & 0.09 & 0.09 & 0.00 \\
\hline Background from $\mathrm{MCO}$ & 0.05 & 0.05 & 0.05 & 0.05 & 0.05 & 0.05 & \\
\hline Duration: Minutes/day & 2 & 3 & 2 & 3 & 10 & 5 & 15 \\
\hline \multirow[t]{2}{*}{ Duration: Hours/day } & 0.033 & $\begin{array}{r}0.050 \\
\end{array}$ & 0.033 & 0.050 & 0.167 & 0.083 & 0.250 \\
\hline & \multicolumn{7}{|c|}{ Load washer, dump fuel onto inspection table and load fuel basket (continued) } \\
\hline \multicolumn{8}{|l|}{ Average canisters per $\mathrm{MCO}$} \\
\hline \multicolumn{8}{|l|}{$\begin{array}{l}\text { Average fuel baskets per } \\
\text { MCO }\end{array}$} \\
\hline \multicolumn{8}{|l|}{ Personnel: } \\
\hline \multicolumn{8}{|l|}{ Crane Operator } \\
\hline \multicolumn{8}{|l|}{ Dose Rate-mrem $/ \mathrm{hr}$} \\
\hline \multicolumn{8}{|l|}{ Dose-person-mrem } \\
\hline Operator (fuel retrieval) & 1 & 1 & 1 & 1 & 1 & 1 & 1 \\
\hline Dose Rate-mrem/hr & 0.14 & 0.14 & 0.14 & 0.14 & 0.14 & 0.14 & 0.00 \\
\hline Dose-person-mrem & 0.00 & 0.01 & 0.00 & 0.01 & 0.02 & 0.01 & 0.00 \\
\hline \multicolumn{8}{|l|}{ Mgr } \\
\hline \multicolumn{8}{|l|}{ Dose Rate-mrem/hr } \\
\hline \multicolumn{8}{|l|}{ Dose-person-mrem } \\
\hline \multicolumn{8}{|l|}{ HPT } \\
\hline \multicolumn{8}{|l|}{ Dose Rate-mrem/hr } \\
\hline \multicolumn{8}{|l|}{ Dose-person-mrem } \\
\hline \multicolumn{8}{|l|}{\begin{tabular}{|l} 
Truck Driver \\
\end{tabular}} \\
\hline \multicolumn{8}{|l|}{ Dose Rate-mrem $/ \mathrm{hr}$} \\
\hline \multicolumn{8}{|l|}{ Dose-person-mrem } \\
\hline \multicolumn{8}{|l|}{ Totals: } \\
\hline & & & & & & & \\
\hline \multicolumn{8}{|l|}{ Crane Operator } \\
\hline Operator (fuel retrieval) & 0.00 & 0.01 & 0.00 & 0.01 & 0.02 & 0.01 & 0.00 \\
\hline \multicolumn{8}{|l|}{$\mathrm{Mgr}$} \\
\hline \multicolumn{8}{|l|}{$\mathrm{HPT}$} \\
\hline \multicolumn{8}{|l|}{ Truck Driver } \\
\hline Step totals per can or basket & 0.00 & 0.01 & 0.00 & 0.01 & 0.02 & 0.01 & 0.00 \\
\hline Step totals per MCO & 0.09 & 0.13 & 0.09 & 0.13 & 0.44 & 0.22 & 0.00 \\
\hline
\end{tabular}


SNF-4977 REV 0

Table A-2. K West Basin Fuel Retrieval System Personnel Doses (sheet 6 of 7)

\begin{tabular}{|c|c|c|c|c|c|c|c|}
\hline $\begin{array}{l}\text { Prepare fuel for loading into } \\
\text { MCO }\end{array}$ & $\begin{array}{l}\text { Inspect } \\
\text { elements }\end{array}$ & $\begin{array}{c}\text { Second } \\
\text { Cleaning of } \\
\text { fuel, as } \\
\text { needed }\end{array}$ & $\begin{array}{c}\text { Record new } \\
\text { fuel basket } \\
\text { number }\end{array}$ & $\begin{array}{l}\text { Load fuel } \\
\text { basket with } \\
\text { fuel }\end{array}$ & $\begin{array}{l}\text { Pick up full } \\
\text { fuel basket }\end{array}$ & $\begin{array}{l}\text { Weigh full } \\
\text { basket and } \\
\text { record }\end{array}$ & $\begin{array}{l}\text { Video full } \\
\text { fuel basket }\end{array}$ \\
\hline Location & Remote & Wash Fuel & Wash Fuel & Remote & Wash Fuel & Wash Fuel & Wash Fuel \\
\hline Background $\mathrm{mr} / \mathrm{hr}$ & 0.00 & 0.09 & 0.09 & 0.00 & 0.09 & 0.09 & 0.09 \\
\hline Background from $\mathrm{MCO}$ & & 0.05 & 0.05 & & 0.05 & 0.05 & 0.05 \\
\hline Duration: Minutes/day & 12 & 10 & 2 & 540 & 1.5 & 2 & 1 \\
\hline Duration: Hours/day & 0.200 & 0.167 & 0.033 & 9.000 & 0.025 & 0.033 & 0.017 \\
\hline & & & & & \multicolumn{3}{|c|}{ Stage full fuel basket } \\
\hline \multicolumn{8}{|l|}{ Average canisters per $\mathrm{MCO}$} \\
\hline \multicolumn{8}{|l|}{$\begin{array}{l}\text { Average fuel baskets per } \\
\mathrm{MCO}\end{array}$} \\
\hline \multicolumn{8}{|l|}{ Personnel: } \\
\hline \multicolumn{8}{|l|}{ Crane Operator } \\
\hline \multicolumn{8}{|l|}{ Dose Rate-mrem/hr } \\
\hline \multicolumn{8}{|l|}{ Dose-person-mrem } \\
\hline Operator (fuel retrieval) & 1 & 1 & 1 & 1 & 1 & 1 & 1 \\
\hline Dose Rate-mrem $/ \mathrm{hr}$ & 0.00 & 0.14 & 0.14 & 0.00 & 0.14 & 0.14 & 0.14 \\
\hline Dose-person-mrem & 0.00 & 0.02 & 0.00 & 0.00 & 0.00 & 0.00 & 0.00 \\
\hline \multicolumn{8}{|l|}{ Mgr } \\
\hline \multicolumn{8}{|l|}{ Dose Rate-mrem/hr } \\
\hline \multicolumn{8}{|l|}{ Dose-person-mrem } \\
\hline \multicolumn{8}{|l|}{ HPT } \\
\hline \multicolumn{8}{|l|}{ Dose Rate-mrem $/ \mathrm{hr}$} \\
\hline \multicolumn{8}{|l|}{ Dose-person-mrem } \\
\hline \multicolumn{8}{|l|}{ Truck Driver } \\
\hline \multicolumn{8}{|l|}{ Dose Rate-mrem $/ \mathrm{hr}$} \\
\hline \multicolumn{8}{|l|}{ Dose-person-mrem } \\
\hline \multicolumn{8}{|l|}{ Totals: } \\
\hline \multicolumn{8}{|l|}{ Crane Operator } \\
\hline Operator (fuel retrieval) & 0.00 & 0.02 & 0.00 & 0.00 & 0.00 & $0 . \overline{00}$ & 0.00 \\
\hline \multicolumn{8}{|l|}{$\mathrm{Mgr}$} \\
\hline \multicolumn{8}{|l|}{ HPT } \\
\hline \multicolumn{8}{|l|}{ Truck Driver } \\
\hline Step totals per can or basket & 0.00 & 0.02 & 0.00 & 0.00 & 0.00 & 0.00 & 0.00 \\
\hline Step totals per MCO & 0.00 & 0.44 & 0.02 & 0.00 & 0.02 & 0.02 & 0.01 \\
\hline
\end{tabular}


Table A-2. K West Basin Fuel Retrieval System Personnel Doses (sheet 7 of 7)

\begin{tabular}{|c|c|c|c|c|}
\hline $\begin{array}{l}\text { Prepare fuel for loading into } \\
\text { MCO }\end{array}$ & $\begin{array}{l}\text { Move full } \\
\text { basket south } \\
\text { on rail }\end{array}$ & $\begin{array}{c}\text { Transfer full } \\
\text { basket to } \\
\text { trolley. Take } \\
\text { to MCO load } \\
\text { staging }\end{array}$ & $\begin{array}{c}\text { Pick up empty } \\
\text { basket; transfer } \\
\text { to inspection } \\
\text { table }\end{array}$ & $\begin{array}{c}\text { All Fuel } \\
\text { Operations } \\
\text { (per } \mathrm{MCO})\end{array}$ \\
\hline Location & Move Bskt & Move Bskt & Move Bskt & \\
\hline Background $\mathrm{mr} / \mathrm{hr}$ & 0.09 & 0.09 & 0.09 & \\
\hline Background from $\mathrm{MCO}$ & 0.05 & 0.16 & 0.16 & \\
\hline Duration: Minutes/day & 0.5 & 5 & 5 & \\
\hline Duration: Hours/day & 0.008 & 0.083 & 0.083 & 105.69 \\
\hline \multicolumn{5}{|l|}{ Average canisters per $\mathrm{MCO}$} \\
\hline \multicolumn{5}{|l|}{$\begin{array}{l}\text { Average fuel baskets per } \\
\text { MCO }\end{array}$} \\
\hline \multicolumn{5}{|l|}{ Personnel: } \\
\hline \multicolumn{5}{|l|}{ Crane Operator } \\
\hline \multicolumn{5}{|l|}{ Dose Rate-mrem/hr } \\
\hline \multicolumn{5}{|l|}{ Dose-person-mrem } \\
\hline Operator (fuel retrieval) & 1 & 1 & 1 & \\
\hline Dose Rate-mrem $/ \mathrm{hr}$ & 0.14 & 0.25 & 0.25 & \\
\hline Dose-person-mrem & 0.00 & 0.02 & 0.02 & 7.08 \\
\hline \multicolumn{5}{|l|}{$\mathrm{Mgr}$} \\
\hline \multicolumn{5}{|l|}{ Dose Rate-mrem/hr } \\
\hline Dose-person-mrem & & & & 0.75 \\
\hline \multicolumn{5}{|l|}{ HPT } \\
\hline \multicolumn{5}{|l|}{ Dose Rate-mrem/hr } \\
\hline Dose-person-mrem & & & & 0.38 \\
\hline \multicolumn{5}{|l|}{ Truck Driver } \\
\hline \multicolumn{5}{|l|}{ Dose Rate-mrem/hr } \\
\hline \multicolumn{5}{|l|}{ Dose-person-mrem } \\
\hline Totals: & & & & 8.21 \\
\hline \multicolumn{5}{|l|}{ Crane Operator } \\
\hline Operator (fuel retrieval) & 0.00 & 0.02 & 0.02 & 7.08 \\
\hline $\mathrm{Mgr}$ & & & & 0.75 \\
\hline HPT & & & & 0.38 \\
\hline \multicolumn{5}{|l|}{ Truck Driver } \\
\hline Step totals per can or basket & 0.00 & 0.02 & 0.02 & 8.21 \\
\hline
\end{tabular}


SNF-4977 REV 0

APPENDIX B

COMPUTATION OF PERSONNEL DOSES DURING CANISTER LOADING SYSTEM OPERATIONS 
SNF-4977 REV 0

This page intentionally left blank. 
SNF-4977 REV 0

\section{APPENDIX B \\ COMPUTATION OF PERSONNEL DOSES DURING CANISTER LOADING SYSTEM OPERATIONS}

Listed below are the spreadsheets (Bullock 1999) used to compute the canister loading system doses (mrem/multi-canister overpack [MCO]) given in Table 5-2. The first spreadsheet (Table B-1) applies to the K East Basin, while the second (Table B-2) applies to the K West Basin.

Dose computations in the spreadsheets are as follows:

$\{$ worker dose rate $\}=\{\mathrm{K}$ Basin background $\}+\{$ background from $\mathrm{MCO}\}$

$\{$ dose-person $\}=\{\text { no. of workers }\}^{*}\{\text { worker dose rate }\}^{*}\{$ duration $\}$

where, dose rate is in $\mathrm{mrem} / \mathrm{h}$, duration is in $\mathrm{h}$, doses are in mrem/MCO, and a worker is either a person-in-charge (mgr in spreadsheets), an operator (operator 1 or operator 2 in spreadsheets), a health physics technician, or a truck driver. The $\mathrm{K}$ Basin background dose rate that each worker receives for a particular activity (listed as background or standby background in the spreadsheets) is defined in Tables 4-4 and 4-1. The MCO background dose rate that each worker receives for a particular activity is one of the four dose rates listed in the spreadsheets under "Dose Field." Table 4-4 identifies which of the four dose rates applies to an activity.

\section{REFERENCE}

Bullock, D. E., 1999, KE and KW Spreadsheets (electronic mail to J. V. Nelson, July 16), Fluor Daniel Hanford Incorporated, Richland, Washington. 
Table B-1. K East Basin Cask Loading System Personnel Doses. (sheet 1 of 6)

\begin{tabular}{|c|c|c|c|c|c|c|c|c|c|c|}
\hline Cask/MCO Handling & $\begin{array}{c}\text { Routine } \\
\text { HPT } \\
\text { survey }\end{array}$ & $\begin{array}{c}\text { Routine } \\
\text { PIC } \\
\text { obser- } \\
\text { vation }\end{array}$ & $\begin{array}{c}\text { Prep } \\
\text { receiving } \\
\text { area }\end{array}$ & $\begin{array}{c}\text { Back } \\
\text { trailer in }\end{array}$ & $\begin{array}{c}\text { Prepare } \\
\text { to } \\
\text { separate } \\
\text { trailer }\end{array}$ & $\begin{array}{c}\text { Separate } \\
\text { trailer \& } \\
\text { remove } \\
\text { tractor }\end{array}$ & $\begin{array}{c}\text { Level } \\
\text { trailer \& } \\
\text { close roll } \\
\text { up door }\end{array}$ & $\begin{array}{c}\text { Rad } \\
\text { survey } \\
\text { of cask }\end{array}$ & $\begin{array}{l}\text { Release } \\
\text { cask tie } \\
\text { downs }\end{array}$ & $\begin{array}{l}\text { Attach } \\
32 \text { ton } \\
\text { crane to } \\
\text { cask lid }\end{array}$ \\
\hline Location & General & General & \begin{tabular}{|c|} 
Truck \\
Loading \\
\end{tabular} & \begin{tabular}{|c|} 
Truck \\
Loading
\end{tabular} & \begin{tabular}{|c|} 
Truck \\
Loading
\end{tabular} & \begin{tabular}{|c|} 
Truck \\
Loading
\end{tabular} & $\begin{array}{c}\text { Truck } \\
\text { Loading }\end{array}$ & \begin{tabular}{|c|} 
Truck \\
Loading
\end{tabular} & $\begin{array}{c}\text { Truck } \\
\text { Loading }\end{array}$ & $\begin{array}{c}\text { Truck } \\
\text { Loading }\end{array}$ \\
\hline Background $\mathrm{mr} / \mathrm{hr}$ & 2.00 & 2.00 & \begin{tabular}{r|}
1.20 \\
\end{tabular} & \begin{tabular}{|r|}
1.20 \\
\end{tabular} & \begin{tabular}{|l|}
1.20 \\
\end{tabular} & \begin{tabular}{|l|}
1.20 \\
\end{tabular} & \begin{tabular}{|l|}
1.20 \\
\end{tabular} & \begin{tabular}{r|}
1.20 \\
\end{tabular} & 1.20 & 1.20 \\
\hline $\begin{array}{l}\text { Standby Background } \\
\mathrm{mrem} / \mathrm{hr}\end{array}$ & 0.50 & 0.50 & 0.50 & 0.50 & 0.50 & 0.50 & 0.50 & 0.50 & 0.50 & 0.50 \\
\hline & & & & & & & & & & \\
\hline \multicolumn{11}{|l|}{ Dose Field } \\
\hline \multicolumn{11}{|l|}{$30 \mathrm{~cm}}$. \\
\hline \multicolumn{11}{|l|}{ one meter } \\
\hline \multicolumn{11}{|l|}{3 meter } \\
\hline \multicolumn{11}{|l|}{5 meter } \\
\hline Duration: Min. in rad zone & 60 & 120 & 60 & 10 & 20 & 20 & 10 & 10 & 10 & 10 \\
\hline Duration: Hrs in rad zone & 1.00 & 2.00 & 1.00 & 0.17 & 0.33 & 0.33 & 0.17 & 0.17 & 0.17 & 0.17 \\
\hline \multicolumn{11}{|l|}{$\begin{array}{l}\text { Duration: Hrs of task, if } \\
\text { different }\end{array}$} \\
\hline & & & & & & & & & & \\
\hline \multicolumn{11}{|l|}{ Personnel: } \\
\hline Operator 1 & & & 1 & 1 & 1 & 1 & 1 & 1 & 1 & 1 \\
\hline Dose Rate-mrem/hr & & & 1.20 & 1.20 & 1.20 & \begin{tabular}{|l|}
1.20 \\
\end{tabular} & 1.20 & 1.20 & 1.20 & 1.20 \\
\hline Dose-person-mrem/MCO & & & 1.20 & 0.20 & 0.40 & 0.40 & 0.20 & 0.20 & 0.20 & 0.20 \\
\hline Operator 2 & & & 1 & 1 & 1 & 1 & 1 & 1 & 1 & 1 \\
\hline Dose Rate-mrem/hr & & & 1.20 & \begin{tabular}{|l|}
0.50 \\
\end{tabular} & 1.20 & \begin{tabular}{|l|}
0.50 \\
\end{tabular} & 0.50 & 0.50 & 1.20 & 1.20 \\
\hline Dose-person-mrem/MCO & & & 1.20 & 0.08 & 0.40 & 0.17 & 0.08 & 0.08 & 0.20 & 0.20 \\
\hline \begin{tabular}{|l|l|} 
Mgr \\
\end{tabular} & & 1 & & & & & & & & \\
\hline Dose Rate-mrem/hr & & \begin{tabular}{|l|}
2.00 \\
\end{tabular} & & & & & & & & \\
\hline Dose-person-mrem/MCO & & 4.00 & & & & & & & & \\
\hline HPT & 1 & & & 1 & 1 & 1 & 1 & 1 & 1 & 1 \\
\hline Dose Rate-mrem/hr & 2.00 & & & 0.50 & 0.50 & 0.50 & 0.50 & 1.20 & 0.50 & 0.50 \\
\hline Dose-person-mrem/MCO & 2.00 & & & 0.08 & 0.17 & 0.17 & 0.08 & 0.20 & 0.08 & 0.08 \\
\hline \begin{tabular}{|l|} 
Truck Driver \\
\end{tabular} & & & & 1 & 1 & 1 & & & & \\
\hline Dose Rate-mrem/hr & & & & 0.50 & \begin{tabular}{|l|}
0.50 \\
\end{tabular} & 0.50 & & & & \\
\hline Dose-person-mrem/MCO & & & & 0.08 & 0.17 & 0.17 & & & & \\
\hline Totals: & 2.00 & 4.00 & 2.40 & 0.45 & 1.13 & 0.90 & 0.37 & 0.48 & 0.48 & 0.48 \\
\hline \multicolumn{11}{|l|}{ Crew Dose: } \\
\hline \multicolumn{11}{|l|}{ Mask } \\
\hline \multicolumn{11}{|l|}{ SWP/shift } \\
\hline & & & & & & & & & & \\
\hline Operator 1 & & & 1.20 & 0.20 & 0.40 & 0.40 & 0.20 & 0.20 & 0.20 & 0.20 \\
\hline Operator 2 & & & 1.20 & 0.08 & 0.40 & 0.17 & 0.08 & 0.08 & 0.20 & 0.20 \\
\hline Mgr & & 4.00 & & & & & & & & \\
\hline HPT & 2.00 & & & 0.08 & 0.17 & 0.17 & 0.08 & 0.20 & 0.08 & 0.08 \\
\hline Truck Driver & & & & 0.08 & 0.17 & 0.17 & & & & \\
\hline Totals: & 2.00 & 4.00 & 2.40 & 0.45 & 1.13 & 0.90 & 0.37 & 0.48 & 0.48 & 0.48 \\
\hline
\end{tabular}


Table B-1. K East Basin Cask Loading System Personnel Doses. (sheet 2 of 6)

\begin{tabular}{|c|c|c|c|c|c|c|c|c|}
\hline Cask/MCO Handling & $\begin{array}{l}\text { Discon- } \\
\text { nect } \\
\text { clamshell }\end{array}$ & $\begin{array}{c}\text { Lift cask } \\
\text { and move } \\
\text { to loadout } \\
\text { pit }\end{array}$ & $\begin{array}{l}\text { Inspect } \\
\text { pail }\end{array}$ & $\begin{array}{l}\text { Put cask } \\
\text { into IP }\end{array}$ & \begin{tabular}{|c|} 
Retrieve \\
torque tool, \\
loosen lid \\
bolts, \\
remove tool, \\
disc. Hoist \\
\end{tabular} & $\begin{array}{l}\text { Attach lid } \\
\text { slings }\end{array}$ & $\begin{array}{l}\text { Remove } \\
\text { cask lid } \\
\text { and store }\end{array}$ & $\begin{array}{c}\text { Remove } \\
32 \text { ton } \\
\text { crane }\end{array}$ \\
\hline Location & \begin{tabular}{c|} 
Truck \\
Loading
\end{tabular} & \begin{tabular}{l|} 
Control \\
Station \\
\end{tabular} & $\begin{array}{c}\text { Loadout } \\
\text { Pit }\end{array}$ & $\begin{array}{c}\text { Loadout } \\
\text { Pit }\end{array}$ & Loadout Pit & \begin{tabular}{c|} 
Loadout \\
Pit
\end{tabular} & \begin{tabular}{c|} 
Loadout \\
Pit
\end{tabular} & $\begin{array}{c}\text { Loadout } \\
\text { Pit }\end{array}$ \\
\hline Background $\mathrm{mr} / \mathrm{hr}$ & 1.20 & 1.20 & 1.50 & 1.50 & 1.50 & 1.50 & 1.50 & 1.50 \\
\hline $\begin{array}{l}\text { Standby Background } \\
\mathrm{mrem} / \mathrm{hr}\end{array}$ & 0.50 & 0.50 & 0.50 & 0.50 & 0.50 & 0.50 & 0.50 & 0.50 \\
\hline \multicolumn{9}{|l|}{ Dose Field } \\
\hline \multicolumn{9}{|l|}{$30 \mathrm{~cm}}$. \\
\hline \multicolumn{9}{|l|}{ one meter } \\
\hline \multicolumn{9}{|l|}{3 meter } \\
\hline \multicolumn{9}{|l|}{5 meter } \\
\hline $\begin{array}{l}\text { Duration: Minutes in rad } \\
\text { zone }\end{array}$ & 10 & 20 & 15 & 10 & 35 & 5 & 15 & 5 \\
\hline Duration: Hours in rad zone & 0.17 & 0.33 & 0.25 & 0.17 & 0.58 & 0.08 & 0.25 & 0.08 \\
\hline \multicolumn{9}{|l|}{$\begin{array}{l}\text { Duration: Hours of task, if } \\
\text { different }\end{array}$} \\
\hline \multicolumn{9}{|l|}{ Personnel: } \\
\hline Operator 1 & 1 & 1 & 1 & 1 & 1 & 1 & 1 & 1 \\
\hline Dose Rate-mrem/hr & 1.20 & 1.20 & 1.50 & 1.50 & 1.50 & 1.50 & 1.50 & 1.50 \\
\hline Dose-person-mrem/MCO & 0.20 & 0.40 & 0.38 & 0.25 & 0.88 & 0.13 & 0.38 & 0.13 \\
\hline Operator 2 & 1 & 1 & 1 & 1 & 1 & 1 & 1 & 1 \\
\hline Dose Rate-mrem/hr & 1.20 & 0.50 & 1.50 & 0.50 & 1.50 & 1.50 & 1.50 & 1.50 \\
\hline Dose-person-mrem/MCO & 0.20 & 0.17 & 0.38 & 0.08 & 0.88 & 0.13 & 0.38 & 0.13 \\
\hline \multicolumn{9}{|l|}{\begin{tabular}{|l|l|}
$\mathrm{Mgr}$ & \\
\end{tabular}} \\
\hline \multicolumn{9}{|l|}{ Dose Rate-mrem/hr } \\
\hline \multicolumn{9}{|l|}{\begin{tabular}{|l|l} 
Dose-person-mrem/MCO & \\
\end{tabular}} \\
\hline $\begin{array}{ll}\mathrm{HPT} & \end{array}$ & 1 & 1 & 1 & 1 & 1 & 1 & 1 & 1 \\
\hline Dose Rate-mrem/hr & 0.50 & 0.50 & 0.50 & 0.50 & 1.50 & 1.50 & 1.50 & 1.50 \\
\hline Dose-person-mrem/MCO & 0.08 & 0.17 & 0.13 & 0.08 & 0.88 & 0.13 & 0.38 & 0.13 \\
\hline \multicolumn{9}{|l|}{ Truck Driver } \\
\hline \multicolumn{9}{|l|}{ Dose Rate-mrem/hr } \\
\hline \multicolumn{9}{|l|}{ Dose-person-mrem/MCO } \\
\hline Totals: & 0.48 & 0.73 & 0.88 & 0.42 & 2.63 & 0.38 & 1.13 & 0.38 \\
\hline \multicolumn{9}{|l|}{ Crew Dose: } \\
\hline \multicolumn{9}{|l|}{ Mask } \\
\hline \multicolumn{9}{|l|}{ SWP/shift } \\
\hline & & & & & & & & \\
\hline Operator 1 & 0.20 & 0.40 & 0.38 & 0.25 & 0.88 & 0.13 & 0.38 & 0.13 \\
\hline Operator 2 & 0.20 & 0.17 & 0.38 & 0.08 & 0.88 & 0.13 & 0.38 & 0.13 \\
\hline \multicolumn{9}{|l|}{ Mgr } \\
\hline HPT & 0.08 & 0.17 & 0.13 & 0.08 & 0.88 & 0.13 & 0.38 & 0.13 \\
\hline \multicolumn{9}{|l|}{\begin{tabular}{|l} 
Truck Driver \\
\end{tabular}} \\
\hline \begin{tabular}{|l} 
Totals: \\
\end{tabular} & 0.48 & 0.73 & 0.88 & 0.42 & 2.63 & 0.38 & 1.13 & 0.38 \\
\hline
\end{tabular}


Table B-1. K East Basin Cask Loading System Personnel Doses. (sheet 3 of 6)

\begin{tabular}{|c|c|c|c|c|c|c|c|c|}
\hline Cask/MCO Handling & $\begin{array}{c}\text { Connect } \\
\text { to IP lid, } \\
\text { install and } \\
\text { test }\end{array}$ & $\begin{array}{c}\text { Fill IP } \\
\text { with water }\end{array}$ & $\begin{array}{l}\text { Remove } \\
\text { locking } \\
\text { ring with } \\
\text { locking } \\
\text { ring tool, } \\
\text { \& store }\end{array}$ & $\begin{array}{c}\text { Fill MCO } \\
\text { with } \\
\text { water, } \\
\text { install } \\
\text { basket } \\
\text { guide }\end{array}$ & $\begin{array}{c}\text { Connect } 32 \\
\text { ton crane to } \\
\text { imm. Pail } \\
\text { with slings }\end{array}$ & $\begin{array}{l}\text { Release } \\
\text { lock pins }\end{array}$ & $\begin{array}{c}\text { Lower IP } \\
\text { system to } \\
\text { bottom }\end{array}$ & $\begin{array}{l}\text { Remove } \\
\text { lift beam, } \\
\text { slings, and } \\
\text { pail from } \\
32 \text { ton } \\
\text { crane and } \\
\text { store }\end{array}$ \\
\hline Location & $\begin{array}{c}\text { Loadout } \\
\text { Pit }\end{array}$ & \begin{tabular}{l|} 
Control \\
Station
\end{tabular} & $\begin{array}{c}\text { Loadout } \\
\text { Pit }\end{array}$ & $\begin{array}{c}\text { Loadout } \\
\text { Pit }\end{array}$ & Loadout Pit & $\begin{array}{c}\text { Loadout } \\
\text { Pit }\end{array}$ & $\begin{array}{l}\text { Control } \\
\text { Station }\end{array}$ & Loadout Pit \\
\hline Background $\mathrm{mr} / \mathrm{hr}$ & 1.50 & 0.02 & 1.50 & 1.50 & 1.50 & 1.50 & 1.20 & 1.50 \\
\hline $\begin{array}{l}\text { Standby Background } \\
\mathrm{mrem} / \mathrm{hr}\end{array}$ & 0.50 & 0.50 & 0.50 & 0.50 & 0.50 & 0.50 & 0.50 & 0.50 \\
\hline & & & & & & & & \\
\hline \multicolumn{9}{|l|}{ Dose Field } \\
\hline \multicolumn{9}{|l|}{$30 \mathrm{~cm}$} \\
\hline \multicolumn{9}{|l|}{ one meter } \\
\hline \multicolumn{9}{|l|}{3 meter } \\
\hline \multicolumn{9}{|l|}{5 meter } \\
\hline $\begin{array}{l}\text { Duration: Minutes in rad } \\
\text { zone }\end{array}$ & 50 & 10 & 50 & 25 & 30 & 10 & 10 & 25 \\
\hline Duration: Hours in rad zone & 0.83 & 0.17 & 0.83 & 0.42 & 0.50 & 0.17 & 0.17 & 0.42 \\
\hline \multicolumn{9}{|l|}{$\begin{array}{l}\text { Duration: Hours of task, if } \\
\text { different }\end{array}$} \\
\hline \multicolumn{9}{|l|}{ Personnel: } \\
\hline Operator 1 & 1 & 1 & 1 & 1 & 1 & 1 & 1 & 1 \\
\hline Dose Rate-mrem/hr & 1.50 & 0.02 & 1.50 & 1.50 & 1.50 & 1.50 & 1.20 & 1.50 \\
\hline Dose-person-mrem/MCO & 1.25 & 0.00 & 1.25 & 0.63 & 0.75 & 0.25 & 0.20 & 0.63 \\
\hline Operator 2 & 1 & 1 & \begin{tabular}{l|l} 
& 1 \\
\end{tabular} & 1 & 1 & 1 & 1 & 1 \\
\hline Dose Rate-mrem/hr & 1.50 & 0.50 & 1.50 & 1.50 & 1.50 & 1.50 & 0.50 & 1.50 \\
\hline Dose-person-mrem/MCO & 1.25 & 0.08 & 1.25 & 0.63 & 0.75 & 0.25 & 0.08 & 0.63 \\
\hline \multicolumn{9}{|l|}{ Mgr } \\
\hline \multicolumn{9}{|l|}{ Dose Rate-mrem/hr } \\
\hline \multicolumn{9}{|l|}{ Dose-person-mrem/MCO } \\
\hline HPT & 1 & 1 & 1 & 1 & 1 & 1 & 1 & 1 \\
\hline Dose Rate-mrem $/ \mathrm{hr}$ & 1.50 & 0.50 & 1.50 & 0.50 & 1.50 & 0.50 & 0.50 & 1.50 \\
\hline Dose-person-mrem/MCO & 1.25 & 0.08 & 1.25 & 0.21 & 0.75 & 0.08 & 0.08 & 0.63 \\
\hline \multicolumn{9}{|l|}{ Truck Driver } \\
\hline \multicolumn{9}{|l|}{ Dose Rate-mrem $/ \mathrm{hr}$} \\
\hline \multicolumn{9}{|l|}{ Dose-person-mrem/MCO } \\
\hline Totals: & 3.75 & 0.17 & 3.75 & 1.46 & 2.25 & 0.58 & 0.37 & 1.88 \\
\hline \multicolumn{9}{|l|}{ Crew Dose: } \\
\hline \multicolumn{9}{|l|}{ Mask } \\
\hline \multicolumn{9}{|l|}{ SWP/shift } \\
\hline & & & & & & & & \\
\hline Operator 1 & 1.25 & 0.00 & 1.25 & 0.63 & 0.75 & 0.25 & 0.20 & 0.63 \\
\hline Operator 2 & 1.25 & 0.08 & 1.25 & 0.63 & 0.75 & 0.25 & 0.08 & 0.63 \\
\hline \multicolumn{9}{|l|}{$\mathrm{Mgr}$} \\
\hline $\mathrm{HPT}$ & 1.25 & 0.08 & 1.25 & 0.21 & 0.75 & 0.08 & 0.08 & 0.63 \\
\hline \multicolumn{9}{|l|}{ Truck Driver } \\
\hline Totals: & 3.75 & 0.17 & 3.75 & 1.46 & 2.25 & 0.58 & 0.37 & 1.88 \\
\hline
\end{tabular}


Table B-1. K East Basin Cask Loading System Personnel Doses. (sheet 4 of 6)

\begin{tabular}{|c|c|c|c|c|c|c|c|c|}
\hline Cask/MCO Handling & $\begin{array}{c}\text { Load } \\
\text { MCO } \\
\text { with fuel } \\
\text { basket }\end{array}$ & $\begin{array}{c}\text { Prepare } \\
\text { MCO } \\
\text { Shield } \\
\text { Plug }\end{array}$ & $\begin{array}{c}\text { Remove } \\
\text { MCO basket } \\
\text { guide and } \\
\text { clean plug } \\
\text { sealing area }\end{array}$ & $\begin{array}{c}\text { Install } \\
\text { MCO } \\
\text { shield } \\
\text { plug }\end{array}$ & \begin{tabular}{|c|} 
Remove \\
plug lift rig \\
and connect \\
pail lift \\
beam and \\
slings \\
\end{tabular} & $\begin{array}{c}\text { Raise IP to } \\
\text { pool } \\
\text { surface }\end{array}$ & $\begin{array}{c}\text { Rinse } \\
\text { MCO top } \\
\text { and pail } \\
\text { lid }\end{array}$ & $\begin{array}{c}\text { Raise pail } \\
\text { and pin in } \\
\text { upper } \\
\text { position }\end{array}$ \\
\hline Location & $\begin{array}{l}\text { Control } \\
\text { Station }\end{array}$ & $\begin{array}{c}\text { Truck } \\
\text { Loading }\end{array}$ & Loadout Pit & $\begin{array}{l}\text { Control } \\
\text { Station }\end{array}$ & Loadout Pit & $\begin{array}{l}\text { Control } \\
\text { Station }\end{array}$ & $\begin{array}{l}\text { Loadout } \\
\text { Pit }\end{array}$ & Loadout Pit \\
\hline Background $\mathrm{mr} / \mathrm{hr}$ & 1.20 & 1.20 & 1.50 & 1.20 & 1.50 & 1.20 & 1.50 & 1.50 \\
\hline $\begin{array}{l}\text { Standby Background } \\
\mathrm{mrem} / \mathrm{hr}\end{array}$ & 0.50 & 0.50 & 0.50 & 0.50 & 0.50 & 0.50 & 0.50 & 0.50 \\
\hline \multicolumn{9}{|l|}{ Dose Field } \\
\hline \multicolumn{9}{|l|}{$30 \mathrm{~cm}$} \\
\hline one meter & & & & & & 10 & 10 & 10 \\
\hline 3 meter & & & & & & 2 & 2 & 2 \\
\hline 5 meter & & & & & & 0.8 & 0.8 & 0.8 \\
\hline $\begin{array}{l}\text { Duration: Minutes in rad } \\
\text { zone }\end{array}$ & 275.0 & 100 & 30 & 15 & 35 & 10 & 10 & 10 \\
\hline Duration: Hours in rad zone & 4.58 & 1.67 & 0.50 & $0 . \overline{25}$ & 0.58 & 0.17 & 0.17 & 0.17 \\
\hline \multicolumn{9}{|l|}{$\begin{array}{l}\text { Duration: Hours of task, if } \\
\text { different }\end{array}$} \\
\hline \multicolumn{9}{|l|}{ Personnel: } \\
\hline Operator 1 & 1 & 1 & 1 & 1 & 1 & 1 & 1 & 1 \\
\hline Dose Rate-mrem $/ \mathrm{hr}$ & 1.20 & 1.20 & 1.50 & 1.20 & 1.50 & 1.20 & 3.50 & 11.50 \\
\hline Dose-person-mrem/MCO & 5.50 & 2.00 & 0.75 & $0 . \overline{30}$ & 0.88 & 0.20 & 0.58 & 1.92 \\
\hline Operator 2 & 1 & 1 & 1 & 1 & 1 & 1 & 1 & 1 \\
\hline Dose Rate-mrem/hr & 1.20 & 1.20 & 1.50 & 1.20 & 1.50 & 3.20 & 3.50 & 11.50 \\
\hline Dose-person-mrem/MCO & 5.50 & 2.00 & 0.75 & 0.30 & 0.88 & 0.53 & 0.58 & 1.92 \\
\hline \multicolumn{9}{|l|}{ Mgr } \\
\hline \multicolumn{9}{|l|}{ Dose Rate-mrem $/ \mathrm{hr}$} \\
\hline \multicolumn{9}{|l|}{ Dose-person-mrem/MCO } \\
\hline $\mathrm{HPT}$ & 1 & 1 & 1 & 1 & 1 & 1 & 1 & I \\
\hline Dose Rate-mrem/hr & 0.50 & 0.50 & 1.50 & 0.50 & 1.50 & 3.20 & 3.50 & 3.50 \\
\hline Dose-person-mrem/MCO & 2.29 & 0.83 & 0.75 & 0.13 & 0.88 & 0.53 & 0.58 & 0.58 \\
\hline \multicolumn{9}{|l|}{ Truck Driver } \\
\hline \multicolumn{9}{|l|}{ Dose Rate-mrem $/ \mathrm{hr}$} \\
\hline \multicolumn{9}{|l|}{ Dose-person-mrem/MCO } \\
\hline Totals: & 13.29 & 4.83 & 2.25 & 0.73 & 2.63 & 1.27 & 1.75 & 4.42 \\
\hline \multicolumn{9}{|l|}{ Crew Dose: } \\
\hline \multicolumn{9}{|l|}{ Mask } \\
\hline \multicolumn{9}{|l|}{ SWP/shift } \\
\hline & & & & & & & & \\
\hline Operator 1 & 5.50 & 2.00 & 0.75 & 0.30 & 0.88 & 0.20 & 0.58 & 1.92 \\
\hline Operator 2 & 5.50 & 2.00 & 0.75 & 0.30 & 0.88 & 0.53 & 0.58 & 1.92 \\
\hline \multicolumn{9}{|l|}{$\mathrm{Mgr}$} \\
\hline $\mathrm{HPT}$ & 2.29 & 0.83 & 0.75 & 0.13 & 0.88 & 0.53 & 0.58 & 0.58 \\
\hline \multicolumn{9}{|l|}{ Truck Driver } \\
\hline Totals: & 13.29 & 4.83 & 2.25 & 0.73 & 2.63 & 1.27 & 1.75 & 4.42 \\
\hline
\end{tabular}


Table B-1. K East Basin Cask Loading System Personnel Doses. (sheet 5 of 6)

\begin{tabular}{|c|c|c|c|c|c|c|c|c|}
\hline Cask/MCO Handling & $\begin{array}{l}\text { Remove } \\
\text { lift slings } \\
\text { and beam } \\
\text { and store }\end{array}$ & $\begin{array}{c}\text { Decon } \\
\text { MCO } \\
\text { shield plug } \\
\text { and IP lid }\end{array}$ & $\begin{array}{c}\text { Clean } \\
\text { threads and } \\
\text { install } \\
\text { locking ring }\end{array}$ & $\begin{array}{l}\text { Deflate IP } \\
\text { lid seals } \\
\text { and } \\
\text { remove } \\
\text { bolts }\end{array}$ & $\begin{array}{l}\text { Remove } \\
\text { IP lid }\end{array}$ & $\begin{array}{c}\text { Adjust } \\
\text { cask water } \\
\text { level with } \\
\text { suction } \\
\text { tool }\end{array}$ & $\begin{array}{l}\text { Install } \\
\text { cask lid } \\
\text { and } \\
\text { torque } \\
\text { bolts }\end{array}$ & $\begin{array}{c}\text { Open cask } \\
\text { port cover } \\
\text { and adjust } \\
\text { gas } \\
\text { composition }\end{array}$ \\
\hline Location & $\begin{array}{l}\text { Loadout } \\
\text { Pit }\end{array}$ & $\begin{array}{l}\text { Loadout } \\
\text { Pit }\end{array}$ & Loadout Pit & $\begin{array}{l}\text { Loadout } \\
\text { Pit }\end{array}$ & $\begin{array}{l}\text { Loadout } \\
\text { Pit }\end{array}$ & $\begin{array}{l}\text { Loadout } \\
\text { Pit }\end{array}$ & $\begin{array}{c}\text { Loadout } \\
\text { Pit }\end{array}$ & Loadout Pit \\
\hline Background $\mathrm{mr} / \mathrm{hr}$ & 1.50 & 1.50 & 1.50 & 1.50 & 1.50 & 1.50 & 1.50 & 1.50 \\
\hline $\begin{array}{l}\text { Standby Background } \\
\mathrm{mrem} / \mathrm{hr}\end{array}$ & 0.50 & 0.50 & 0.50 & 0.50 & 0.50 & 0.50 & 0.50 & 0.50 \\
\hline \multirow{2}{*}{\multicolumn{9}{|c|}{ Dose Field }} \\
\hline & & & & & & & & \\
\hline $30 \mathrm{~cm}$ & & & & & & & 0.2 & 0.2 \\
\hline one meter & 10 & 10 & 10 & 1.3 & 1.3 & 1.3 & 0.1 & 0.1 \\
\hline 3 meter & 2 & 2 & 2 & & & & & \\
\hline 5 meter & 0.8 & 0.8 & 0.8 & & & & & \\
\hline $\begin{array}{l}\text { Duration: Minutes in rad } \\
\text { zone }\end{array}$ & 20 & 15 & 85 & 35 & 25 & 15 & 85 & 35 \\
\hline Duration: Hours in rad zone & 0.33 & 0.25 & 1.42 & 0.58 & 0.42 & 0.25 & 1.42 & 0.58 \\
\hline $\begin{array}{l}\text { Duration: Hours of task, if } \\
\text { different }\end{array}$ & & & & 0.10 & 0.20 & & 0.50 & \\
\hline \multicolumn{9}{|l|}{ Personnel: } \\
\hline Operator 1 & 1 & 1 & 1 & 1 & 1 & 1 & 1 & 1 \\
\hline Dose Rate-mrem/hr & 11.50 & 11.50 & 11.50 & 2.80 & 2.80 & 2.80 & 1.60 & 1.60 \\
\hline Dose-person-mrem/MCO & 3.83 & 2.88 & 16.29 & 1.63 & 1.17 & 0.70 & 2.27 & 0.93 \\
\hline \begin{tabular}{l|l} 
Operator 2 \\
\end{tabular} & 1 & 1 & 1 & 1 & 1 & 1 & 1 & 1 \\
\hline Dose Rate-mrem $/ \mathrm{hr}$ & 11.50 & 11.50 & \begin{tabular}{l|l}
11.50 \\
\end{tabular} & 2.80 & \begin{tabular}{l|l}
2.80 \\
\end{tabular} & 2.80 & 1.60 & 1.60 \\
\hline Dose-person-mrem/MCO & 3.83 & 2.88 & 16.29 & 1.63 & 1.17 & 0.70 & 2.27 & 0.93 \\
\hline \multicolumn{9}{|l|}{ Mgr } \\
\hline \multicolumn{9}{|l|}{ Dose Rate-mrem/hr } \\
\hline \multicolumn{9}{|l|}{ Dose-person-mrem/MCO } \\
\hline HPT & 1 & 1 & 1 & 1 & 1 & 1 & 1 & 1 \\
\hline Dose Rate-mrem/hr & 11.50 & 11.50 & 11.50 & 2.80 & 2.80 & 2.80 & 1.60 & 1.60 \\
\hline Dose-person-mrem/MCO & 3.83 & 2.88 & 16.29 & 1.63 & 1.17 & 0.70 & 2.27 & 0.93 \\
\hline \multicolumn{9}{|l|}{ Truck Driver } \\
\hline \multicolumn{9}{|l|}{ Dose Rate-mrem/hr } \\
\hline \multicolumn{9}{|l|}{ Dose-person-mrem/MCO } \\
\hline Totals: & 11.50 & 8.63 & 48.88 & 4.90 & 3.50 & 2.10 & 6.80 & 2.80 \\
\hline \multicolumn{9}{|l|}{ Crew Dose: } \\
\hline \multicolumn{9}{|l|}{ Mask } \\
\hline \multicolumn{9}{|l|}{ SWP/shift } \\
\hline Operator 1 & 3.83 & 2.88 & 16.29 & 1.63 & 1.17 & 0.70 & 2.27 & 0.93 \\
\hline Operator 2 & 3.83 & 2.88 & 16.29 & 1.63 & 1.17 & 0.70 & 2.27 & 0.93 \\
\hline \multicolumn{9}{|l|}{$\mathrm{Mgr}$} \\
\hline $\mathrm{HPT}$ & 3.83 & 2.88 & 16.29 & 1.63 & 1.17 & 0.70 & 2.27 & 0.93 \\
\hline \multicolumn{9}{|l|}{ Truck Driver } \\
\hline Totals: & 11.50 & 8.63 & 48.88 & 4.90 & 3.50 & 2.10 & 6.80 & 2.80 \\
\hline
\end{tabular}


Table B-1. K East Basin Cask Loading System Personnel Doses. (sheet 6 of 6 )

\begin{tabular}{|c|c|c|c|c|c|c|c|c|}
\hline Cask/MCO Handling & $\begin{array}{c}\text { Attach } \\
\text { crane to } \\
\text { cask and } \\
\text { raise from } \\
\text { IP }\end{array}$ & $\begin{array}{c}\text { Dry, } \\
\text { survey and } \\
\text { smear cask } \\
\text { surface }\end{array}$ & $\begin{array}{c}\text { Move cask } \\
\text { and tiedown } \\
\text { on trailer }\end{array}$ & $\begin{array}{l}\text { Connect } \\
\text { tractor to } \\
\text { trailer }\end{array}$ & $\begin{array}{l}\text { Perform } \\
\text { final } \\
\text { radiation } \\
\text { survey }\end{array}$ & $\begin{array}{c}\text { Release } \\
\text { cask for } \\
\text { transfer to } \\
\text { CVD }\end{array}$ & $\begin{array}{l}\text { Drive } \\
\text { trailer } \\
\text { away }\end{array}$ & $\begin{array}{c}\text { Total } \\
\text { (per } \mathrm{MCO})\end{array}$ \\
\hline Location & $\begin{array}{l}\text { Loadout } \\
\text { Pit }\end{array}$ & $\begin{array}{c}\text { Truck } \\
\text { Loading }\end{array}$ & $\begin{array}{l}\text { Truck } \\
\text { Loading }\end{array}$ & $\begin{array}{l}\text { Truck } \\
\text { Loading }\end{array}$ & $\begin{array}{c}\text { Truck } \\
\text { Loading }\end{array}$ & $\begin{array}{c}\text { Truck } \\
\text { Loading }\end{array}$ & $\begin{array}{c}\text { Truck } \\
\text { Loading }\end{array}$ & \\
\hline Background $\mathrm{mr} / \mathrm{hr}$ & 1.50 & 1.20 & 1.20 & 1.20 & 1.20 & 1.20 & 1.20 & \\
\hline $\begin{array}{l}\text { Standby Background } \\
\mathrm{mrem} / \mathrm{hr}\end{array}$ & 0.50 & 0.50 & 0.50 & 0.50 & 0.50 & 0.50 & 0.50 & \\
\hline & & & & & & & & \\
\hline \multicolumn{9}{|l|}{ Dose Field } \\
\hline \multicolumn{9}{|l|}{$30 \mathrm{~cm}}$. \\
\hline one meter & 7 & 7 & 7 & 7 & 7 & 7 & 7 & \\
\hline 3 meter & 3.5 & 3.5 & 3.5 & 3.5 & 3.5 & 3.5 & 3.5 & \\
\hline 5 meter & 0.9 & 0.9 & 0.9 & 0.9 & 0.9 & 0.9 & 0.9 & \\
\hline $\begin{array}{l}\text { Duration: Minutes in rad } \\
\text { zone }\end{array}$ & 20 & 105 & 60 & 45 & 20 & 5 & 5 & \\
\hline Duration: Hours in rad zone & 0.33 & 1.75 & 1.00 & 0.75 & 0.33 & 0.08 & 0.08 & 28.58 \\
\hline \multicolumn{9}{|l|}{$\begin{array}{l}\text { Duration: Hours of task, if } \\
\text { different }\end{array}$} \\
\hline \multicolumn{9}{|l|}{ Personnel: } \\
\hline Operator 1 & 1 & 1 & 1 & 1 & 1 & 1 & 1 & \\
\hline Dose Rate-mrem/hr & 5.00 & 8.20 & 8.20 & 4.70 & 4.70 & 2.10 & 2.10 & \\
\hline Dose-person-mrem/MCO & 1.67 & 14.35 & 8.20 & 3.53 & 1.57 & 0.18 & 0.18 & 82.16 \\
\hline Operator 2 & 1 & 1 & 1 & & 1 & 1 & & \\
\hline Dose Rate-mrem/hr & 0.50 & 4.70 & 8.20 & 4.70 & 4.70 & 2.10 & 8.20 & \\
\hline Dose-person-mrem/MCO & 0.17 & 8.23 & 8.20 & & 1.57 & 0.18 & & 70.15 \\
\hline \multicolumn{9}{|l|}{ Mgr } \\
\hline \multicolumn{9}{|l|}{ Dose Rate-mrem $/ \mathrm{hr}$} \\
\hline Dose-person-mrem/MCO & & & & & & & & 4.00 \\
\hline $\mathrm{HPT}$ & 1 & 1 & 1 & 1 & 1 & 1 & 1 & \\
\hline Dose Rate-mrem/hr & 8.50 & 8.20 & 4.70 & 4.70 & 8.20 & 1.20 & 1.20 & \\
\hline Dose-person-mrem/MCO & 2.83 & 14.35 & 4.70 & 3.53 & 2.73 & 0.10 & 0.10 & 73.78 \\
\hline Truck Driver & & & & 1 & & 1 & 1 & \\
\hline Dose Rate-mrem $/ \mathrm{hr}$ & & & & 4.00 & & 1.40 & 1.40 & \\
\hline Dose-person-mrem/MCO & & & & 3.00 & & 0.12 & 0.12 & 3.65 \\
\hline Totals: & 4.67 & 36.93 & 21.10 & 10.05 & 5.87 & 0.57 & 0.39 & 233.74 \\
\hline \multicolumn{9}{|l|}{ Crew Dose: } \\
\hline \multicolumn{9}{|l|}{ Mask } \\
\hline \multicolumn{9}{|l|}{ SWP/shift } \\
\hline & & & & & & & & \\
\hline Operator 1 & 1.67 & 14.35 & 8.20 & 3.53 & 1.57 & 0.18 & 0.18 & 82.16 \\
\hline Operator 2 & 0.17 & 8.23 & 8.20 & & 1.57 & 0.18 & & 70.15 \\
\hline $\mathrm{Mgr}$ & & & & & & & & 4.00 \\
\hline HPT & 2.83 & 14.35 & 4.70 & 3.53 & 2.73 & 0.10 & 0.10 & 73.78 \\
\hline Truck Driver & & & & 3.00 & & 0.12 & 0.12 & 3.65 \\
\hline
\end{tabular}


Table B-2. K West Basin Cask Loading System Personnel Doses. (sheet 1 of 6)

\begin{tabular}{|c|c|c|c|c|c|c|c|c|c|c|}
\hline Cask/MCO Handling & $\begin{array}{c}\text { Routine } \\
\text { HPT } \\
\text { survey }\end{array}$ & $\begin{array}{c}\text { Routine } \\
\text { PIC } \\
\text { obser- } \\
\text { vation }\end{array}$ & $\begin{array}{c}\text { Prep } \\
\text { receiv- } \\
\text { ing area }\end{array}$ & $\begin{array}{c}\text { Back } \\
\text { trailer in }\end{array}$ & $\begin{array}{c}\text { Prepare } \\
\text { to } \\
\text { separate } \\
\text { trailer }\end{array}$ & $\begin{array}{c}\text { Separate } \\
\text { trailer \& } \\
\text { remove } \\
\text { tractor }\end{array}$ & $\begin{array}{l}\text { Level } \\
\text { trailer \& } \\
\text { close } \\
\text { roll up } \\
\text { door }\end{array}$ & $\begin{array}{c}\text { Rad } \\
\text { survey } \\
\text { of cask }\end{array}$ & $\begin{array}{c}\text { Release } \\
\text { cask } \\
\text { tiedowns }\end{array}$ & $\begin{array}{l}\text { Attach } \\
32 \text { ton } \\
\text { crane to } \\
\text { cask lid }\end{array}$ \\
\hline Location & General & General & \begin{tabular}{|l|} 
Truck \\
Loading
\end{tabular} & \begin{tabular}{|c|} 
Truck \\
Loading
\end{tabular} & \begin{tabular}{|c|} 
Truck \\
Loading
\end{tabular} & \begin{tabular}{|c|} 
Truck \\
Loading
\end{tabular} & \begin{tabular}{|c|} 
Truck \\
Loading
\end{tabular} & \begin{tabular}{|c|} 
Truck \\
Loading
\end{tabular} & $\begin{array}{c}\text { Truck } \\
\text { Loading }\end{array}$ & $\begin{array}{c}\text { Truck } \\
\text { Loading }\end{array}$ \\
\hline Background $\mathrm{mr} / \mathrm{hr}$ & 0.13 & 0.13 & 0.02 & 0.02 & 0.02 & 0.02 & 0.02 & 0.02 & 0.02 & 0.02 \\
\hline $\begin{array}{l}\text { Standby Background } \\
\mathrm{mrem} / \mathrm{hr}\end{array}$ & 0.01 & 0.01 & 0.01 & 0.01 & 0.01 & 0.01 & 0.01 & 0.01 & 0.01 & 0.01 \\
\hline & & & & & & & & & & \\
\hline \multicolumn{11}{|l|}{ Dose Field } \\
\hline \multicolumn{11}{|l|}{$30 \mathrm{~cm}$} \\
\hline \multicolumn{11}{|l|}{ one meter } \\
\hline \multicolumn{11}{|l|}{3 meter } \\
\hline \multicolumn{11}{|l|}{5 meter } \\
\hline Duration: Min. in rad zone & 60 & 120 & 60 & 10 & 20 & 20 & 10 & 10 & 10 & 10 \\
\hline Duration: Hrs in rad zone & 1.00 & 2.00 & 1.00 & 0.17 & 0.33 & 0.33 & 0.17 & 0.17 & 0.17 & 0.17 \\
\hline & & & & & & & & & & \\
\hline & & & & & & & & & & \\
\hline \multicolumn{11}{|l|}{ Personnel: } \\
\hline Operator 1 & & & 1 & 1 & 1 & 1 & 1 & 1 & 1 & 1 \\
\hline Dose Rate-mrem $/ \mathrm{hr}$ & & & 0.02 & 0.02 & 0.02 & 0.02 & 0.02 & 0.02 & 0.02 & 0.02 \\
\hline Dose-person-mrem/MCO & & & 0.02 & 0.00 & 0.01 & 0.01 & 0.00 & 0.00 & 0.00 & 0.00 \\
\hline Operator 2 & & & 1 & 1 & 1 & 1 & 1 & 1 & 1 & 1 \\
\hline Dose Rate-mrem/hr & & & 0.02 & 0.01 & 0.02 & 0.01 & 0.01 & 0.01 & 0.02 & 0.02 \\
\hline Dose-person-mrem/MCO & & & 0.02 & 0.00 & 0.01 & 0.00 & 0.00 & 0.00 & 0.00 & 0.00 \\
\hline $\mathrm{Mgr}$ & & 1 & & & & & & & & \\
\hline Dose Rate-mrem/hr & & 0.13 & & & & & & & & \\
\hline Dose-person-mrem/MCO & & 0.25 & & & & & & & & \\
\hline $\mathrm{HPT}$ & 1 & & & 1 & 1 & 1 & 1 & 1 & 1 & 1 \\
\hline Dose Rate-mrem $/ \mathrm{hr}$ & 0.13 & & & 0.01 & 0.01 & 0.01 & 0.01 & 0.02 & 0.01 & 0.01 \\
\hline Dose-person-mrem/MCO & 0.13 & & & 0.00 & 0.00 & 0.00 & 0.00 & 0.00 & 0.00 & 0.00 \\
\hline Truck Driver & & & & 1 & 1 & 1 & & & & \\
\hline Dose Rate-mrem/hr & & & & 0.01 & 0.01 & 0.01 & & & & \\
\hline Dose-person-mrem/MCO & & & & 0.00 & 0.00 & 0.00 & & & & \\
\hline Totals: & 0.13 & 0.25 & 0.03 & 0.01 & 0.02 & 0.02 & 0.01 & 0.01 & 0.01 & 0.01 \\
\hline \multicolumn{11}{|l|}{ Crew Dose: } \\
\hline \multicolumn{11}{|l|}{ Mask } \\
\hline \multicolumn{11}{|l|}{ SWP/shift } \\
\hline & & & & & & & & & & 800 \\
\hline Operator 1 & & & 0.02 & 0.00 & 0.01 & 0.01 & 0.00 & 0.00 & 0.00 & 0.00 \\
\hline Operator 2 & & & 0.02 & 0.00 & 0.01 & 0.00 & 0.00 & 0.00 & 0.00 & 0.00 \\
\hline Mgr & & 0.25 & & & & & & & & \\
\hline HPT & 0.13 & & & 0.00 & 0.00 & 0.00 & 0.00 & 0.00 & 0.00 & 0.00 \\
\hline Truck Driver & & & & 0.00 & 0.00 & 0.00 & & & & \\
\hline Totals: & 0.13 & 0.25 & 0.03 & 0.01 & 0.02 & 0.02 & 0.01 & 0.01 & 0.01 & 0.01 \\
\hline
\end{tabular}


Table B-2. K West Basin Cask Loading System Personnel Doses. (sheet 2 of 6)

\begin{tabular}{|c|c|c|c|c|c|c|c|c|}
\hline Cask/MCO Handling & $\begin{array}{c}\text { Discon- } \\
\text { nect } \\
\text { clamshell }\end{array}$ & $\begin{array}{c}\text { Lift cask } \\
\text { and move } \\
\text { to loadout } \\
\text { pit }\end{array}$ & $\begin{array}{l}\text { Inspect } \\
\text { pail }\end{array}$ & $\begin{array}{l}\text { Put cask } \\
\text { into IP }\end{array}$ & \begin{tabular}{|c|} 
Retrieve \\
torque tool, \\
loosen lid \\
bolts, \\
remove tool, \\
disc. Hoist \\
\end{tabular} & $\begin{array}{l}\text { Attach lid } \\
\text { slings }\end{array}$ & $\begin{array}{l}\text { Remove } \\
\text { cask lid } \\
\text { and store }\end{array}$ & $\begin{array}{c}\text { Remove } \\
32 \text { ton } \\
\text { crane }\end{array}$ \\
\hline Location & $\begin{array}{c}\text { Truck } \\
\text { Loading }\end{array}$ & $\begin{array}{l}\text { Control } \\
\text { Station }\end{array}$ & $\begin{array}{l}\text { Loadout } \\
\text { Pit }\end{array}$ & $\begin{array}{l}\text { Loadout } \\
\text { Pit }\end{array}$ & Loadout Pit & $\begin{array}{l}\text { Loadout } \\
\text { Pit }\end{array}$ & $\begin{array}{l}\text { Loadout } \\
\text { Pit }\end{array}$ & $\begin{array}{l}\text { Loadout } \\
\text { Pit }\end{array}$ \\
\hline Background $\mathrm{mr} / \mathrm{hr}$ & 0.02 & 0.02 & 0.13 & 0.13 & 0.13 & 0.13 & 0.13 & 0.13 \\
\hline $\begin{array}{l}\text { Standby Background } \\
\mathrm{mrem} / \mathrm{hr}\end{array}$ & 0.01 & 0.01 & 0.01 & 0.01 & 0.01 & 0.01 & 0.01 & 0.01 \\
\hline Dose Field & & & & & & & 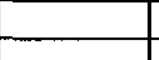 & \\
\hline \multicolumn{9}{|l|}{$30 \mathrm{~cm}$} \\
\hline \multicolumn{9}{|l|}{ one meter } \\
\hline \multicolumn{9}{|l|}{3 meter } \\
\hline \multicolumn{9}{|l|}{5 meter } \\
\hline $\begin{array}{l}\text { Duration: Minutes in rad } \\
\text { zone }\end{array}$ & 10 & 20 & 15 & 10 & 35 & 5 & 15 & 5 \\
\hline Duration: Hours in rad zone & 0.17 & 0.33 & 0.25 & 0.17 & 0.58 & 0.08 & 0.25 & 0.08 \\
\hline \multicolumn{9}{|l|}{$\begin{array}{l}\text { Duration: Hours of task, if } \\
\text { different }\end{array}$} \\
\hline \multicolumn{9}{|l|}{ Personnel: } \\
\hline Operator 1 & 1 & 1 & 1 & 1 & 1 & 1 & 1 & 1 \\
\hline Dose Rate-mrem/hr & 0.02 & 0.02 & 0.13 & 0.13 & $0 . \overline{13}$ & 0.13 & 0.13 & 0.13 \\
\hline Dose-person-mrem/MCO & 0.00 & 0.01 & 0.03 & 0.02 & 0.07 & 0.01 & 0.03 & 0.01 \\
\hline Operator 2 & 1 & 1 & 1 & 1 & 1 & 1 & 1 & 1 \\
\hline Dose Rate-mrem $/ \mathrm{hr}$ & 0.02 & 0.01 & 0.13 & 0.01 & 0,13 & 0.13 & 0.13 & 0.13 \\
\hline Dose-person-mrem/MCO & 0.00 & 0.00 & 0.03 & 0.00 & 0.07 & 0.01 & 0.03 & 0.01 \\
\hline \multicolumn{9}{|l|}{$\mathrm{Mgr}$} \\
\hline \multicolumn{9}{|l|}{ Dose Rate-mrem/hr } \\
\hline \multicolumn{9}{|l|}{ Dose-person-mrem/MCO } \\
\hline HPT & 1 & 1 & 1 & 1 & 1 & 1 & 1 & 1 \\
\hline Dose Rate-mrem/hr & 0.01 & 0.01 & 0.01 & 0.01 & 0.13 & 0.13 & \begin{tabular}{l|l}
0.13 \\
\end{tabular} & 0.13 \\
\hline Dose-person-mrem/MCO & 0.00 & 0.00 & 0.00 & 0.00 & 0.07 & 0.01 & 0.03 & 0.01 \\
\hline \multicolumn{9}{|l|}{ Truck Driver } \\
\hline \multicolumn{9}{|l|}{ Dose Rate-mrem $/ \mathrm{hr}$} \\
\hline \multicolumn{9}{|l|}{ Dose-person-mrem/MCO } \\
\hline Totals: & 0.01 & 0.01 & 0.07 & 0.02 & 0.22 & 0.03 & 0.09 & 0.03 \\
\hline \multicolumn{9}{|l|}{ Crew Dose: } \\
\hline \multicolumn{9}{|l|}{ Mask } \\
\hline \multicolumn{9}{|l|}{ SWP/shift } \\
\hline Onerator 1 & 000 & 001 & 003 & 002 & 007 & 001 & 003 & 0.01 \\
\hline Operator 2 & 0.00 & 0.00 & 0.03 & 0.00 & 0.07 & 0.01 & 0.03 & 0.01 \\
\hline \multicolumn{9}{|l|}{ Mgr } \\
\hline HPT & 0.00 & 0.00 & 0.00 & 0.00 & 0.07 & 0.01 & 0.03 & 0.01 \\
\hline \multicolumn{9}{|l|}{ Truck Driver } \\
\hline Totals: & 0.01 & 0.01 & 0.07 & 0.02 & 0.22 & 0.03 & 0.09 & 0.03 \\
\hline
\end{tabular}


Table B-2. K West Basin Cask Loading System Personnel Doses. (sheet 3 of 6)

\begin{tabular}{|c|c|c|c|c|c|c|c|c|}
\hline Cask/MCO Handling & $\begin{array}{c}\text { Connect } \\
\text { to IP lid, } \\
\text { install and } \\
\text { test }\end{array}$ & $\begin{array}{c}\text { Fill IP } \\
\text { with water }\end{array}$ & $\begin{array}{l}\text { Remove } \\
\text { locking } \\
\text { ring with } \\
\text { locking } \\
\text { ring tool, } \\
\text { \& store }\end{array}$ & $\begin{array}{c}\text { Fill MCO } \\
\text { with } \\
\text { water, } \\
\text { install } \\
\text { basket } \\
\text { guide }\end{array}$ & $\begin{array}{c}\text { Connect } 32 \\
\text { ton crane to } \\
\text { imm. Pail } \\
\text { with slings }\end{array}$ & $\begin{array}{l}\text { Release } \\
\text { lock pins }\end{array}$ & $\begin{array}{c}\text { Lower IP } \\
\text { system to } \\
\text { bottom }\end{array}$ & $\begin{array}{l}\text { Remove } \\
\text { lift beam, } \\
\text { slings, and } \\
\text { pail from } \\
32 \text { ton } \\
\text { crane and } \\
\text { store }\end{array}$ \\
\hline Location & $\begin{array}{l}\text { Loadout } \\
\text { Pit }\end{array}$ & $\begin{array}{l}\text { Control } \\
\text { Station }\end{array}$ & $\begin{array}{l}\text { Loadout } \\
\text { Pit }\end{array}$ & $\begin{array}{c}\text { Loadout } \\
\text { Pit }\end{array}$ & Loadout Pit & $\begin{array}{c}\text { Loadout } \\
\text { Pit }\end{array}$ & $\begin{array}{l}\text { Control } \\
\text { Station }\end{array}$ & Loadout Pit \\
\hline Background $\mathrm{mr} / \mathrm{hr}$ & 0.13 & 0,02 & 0.13 & 0.13 & 0.13 & 0.13 & 0.02 & 0.13 \\
\hline $\begin{array}{l}\text { Standby Background } \\
\mathrm{mrem} / \mathrm{hr}\end{array}$ & 0.01 & 0.01 & 0.01 & 0.01 & 0.01 & 0.01 & 0.01 & 0.01 \\
\hline \multicolumn{9}{|l|}{ Dose Field } \\
\hline \multicolumn{9}{|l|}{$30 \mathrm{~cm}$} \\
\hline \multicolumn{9}{|l|}{ one meter } \\
\hline \multicolumn{9}{|l|}{3 meter } \\
\hline \multicolumn{9}{|l|}{5 meter } \\
\hline $\begin{array}{l}\text { Duration: Minutes in rad } \\
\text { zone }\end{array}$ & 50 & 10 & 50 & 25 & 30 & 10 & 10 & 25 \\
\hline Duration: Hours in rad zone & 0.83 & 0.17 & 0.83 & 0.42 & 0.50 & 0.17 & 0.17 & 0.42 \\
\hline \multicolumn{9}{|l|}{$\begin{array}{l}\text { Duration: Hours of task, if } \\
\text { different }\end{array}$} \\
\hline \multicolumn{9}{|l|}{ Personnel: } \\
\hline Operator 1 & 1 & 1 & 1 & 1 & 1 & 1 & 1 & 1 \\
\hline Dose Rate-mrem/hr & 0.13 & 0.02 & 0.13 & 0.13 & 0.13 & 0.13 & 0.02 & 0.13 \\
\hline Dose-person-mrem/MCO & 0.10 & 0.00 & 0.10 & 0.05 & 0.06 & 0.02 & 0.00 & 0.05 \\
\hline Operator 2 & 1 & 1 & 1 & 1 & 1 & 1 & 1 & 1 \\
\hline Dose Rate-mrem/hr & 0.13 & 0.01 & 0.13 & 0.13 & 0.13 & 0.13 & 0.01 & 0.13 \\
\hline Dose-person-mrem/MCO & 0.10 & 0.00 & 0.10 & 0.05 & 0.06 & 0.02 & 0.00 & 0.05 \\
\hline \multicolumn{9}{|l|}{ Mgr } \\
\hline \multicolumn{9}{|l|}{ Dose Rate-mrem/hr } \\
\hline \multicolumn{9}{|l|}{ Dose-person-mrem/MCO } \\
\hline $\mathrm{HPT}$ & 1 & 1 & 1 & 1 & 1 & 1 & 1 & 1 \\
\hline Dose Rate-mrem/hr & 0.13 & 0.01 & 0.13 & 0.01 & 0.13 & 0.01 & 0.01 & 0.13 \\
\hline Dose-person-mrem/MCO & 0.10 & 0.00 & 0.10 & 0.00 & 0.06 & 0.00 & 0.00 & 0.05 \\
\hline \multicolumn{9}{|l|}{ Truck Driver } \\
\hline \multicolumn{9}{|l|}{ Dose Rate-mrem $/ \mathrm{hr}$} \\
\hline \multicolumn{9}{|l|}{ Dose-person-mrem/MCO } \\
\hline Totals: & 0.31 & 0.01 & 0.31 & 0.11 & 0.19 & 0.04 & 0.01 & 0.16 \\
\hline \multicolumn{9}{|l|}{ Crew Dose: } \\
\hline \multicolumn{9}{|l|}{ Mask } \\
\hline \multicolumn{9}{|l|}{ SWP/shift } \\
\hline & & & & & & & & \\
\hline Operator 1 & 0.10 & 0.00 & 0.10 & 0.05 & 0.06 & 0.02 & 0.00 & 0.05 \\
\hline Operator 2 & 0.10 & 0.00 & 0.10 & 0.05 & 0.06 & 0.02 & 0.00 & 0.05 \\
\hline \multicolumn{9}{|l|}{ Mgr } \\
\hline $\mathrm{HPT}$ & 0.10 & 0.00 & 0.10 & 0.00 & 0.06 & 0.00 & 0.00 & 0.05 \\
\hline \multicolumn{9}{|l|}{ Truck Driver } \\
\hline Totals: & 0.31 & 0.01 & 0.31 & 0.11 & 0.19 & 0.04 & 0.01 & 0.16 \\
\hline
\end{tabular}


Table B-2. K West Basin Cask Loading System Personnel Doses. (sheet 4 of 6)

\begin{tabular}{|c|c|c|c|c|c|c|c|c|}
\hline Cask/MCO Handling & $\begin{array}{c}\text { Load } \\
\text { MCO } \\
\text { with fuel } \\
\text { basket }\end{array}$ & $\begin{array}{c}\text { Prepare } \\
\text { MCO } \\
\text { Shield } \\
\text { Plug }\end{array}$ & $\begin{array}{c}\text { Remove } \\
\text { MCO basket } \\
\text { guide and } \\
\text { clean plug } \\
\text { sealing area }\end{array}$ & $\begin{array}{l}\text { Install } \\
\text { MCO } \\
\text { shield } \\
\text { plug }\end{array}$ & \begin{tabular}{|c|} 
Remove \\
plug lift rig \\
and connect \\
pail lift \\
beam and \\
slings \\
\end{tabular} & $\begin{array}{c}\text { Raise IP to } \\
\text { pool } \\
\text { surface }\end{array}$ & $\begin{array}{c}\text { Rinse } \\
\text { MCO top } \\
\text { and pail } \\
\text { lid }\end{array}$ & $\begin{array}{l}\text { Raise pail } \\
\text { and pin in } \\
\text { upper } \\
\text { position }\end{array}$ \\
\hline Location & $\begin{array}{l}\text { Control } \\
\text { Station }\end{array}$ & $\begin{array}{c}\text { Truck } \\
\text { Loading }\end{array}$ & Loadout Pit & \begin{tabular}{|l|} 
Control \\
Station \\
\end{tabular} & Loadout Pit & $\begin{array}{l}\text { Control } \\
\text { Station } \\
\end{array}$ & $\begin{array}{c}\text { Loadout } \\
\text { Pit }\end{array}$ & Loadout Pit \\
\hline Background $\mathrm{mr} / \mathrm{hr}$ & 0.02 & 0.02 & 0.13 & 0.02 & 0.13 & 0.02 & 0.13 & $\overline{0.13}$ \\
\hline $\begin{array}{l}\text { Standby Background } \\
\text { mrem/hr }\end{array}$ & 0.01 & 0.01 & 0.01 & 0.01 & 0.01 & 0.01 & 0.01 & 0.01 \\
\hline & & & & & & & & \\
\hline \multicolumn{9}{|l|}{ Dose Field } \\
\hline \multicolumn{9}{|l|}{$30 \mathrm{~cm}$} \\
\hline one meter & & & & & & 10 & 10 & 10 \\
\hline 3 meter & & & & & & 2 & 2 & 2 \\
\hline 5 meter & & & & & & 0.8 & 0.8 & 0.8 \\
\hline $\begin{array}{l}\text { Duration: Minutes in rad } \\
\text { zone }\end{array}$ & 275.0 & 100 & 30 & 15 & 35 & 10 & 10 & 10 \\
\hline Duration: Hours in rad zone & 4.58 & 1.67 & 0.50 & 0.25 & 0.58 & 0.17 & 0.17 & 0.17 \\
\hline \multicolumn{9}{|l|}{$\begin{array}{l}\text { Duration: Hours of task, if } \\
\text { different }\end{array}$} \\
\hline \multicolumn{9}{|l|}{ Personnel: } \\
\hline Operator 1 & 1 & 1 & 1 & 1 & 1 & 1 & 1 & 1 \\
\hline Dose Rate-mrem/hr & 0.02 & 0.02 & 0.13 & 0.02 & 0.13 & 0.02 & 2.13 & 10.13 \\
\hline Dose-person-mrem/MCO & 0.08 & 0.03 & 0.06 & 0.00 & 0.07 & 0.00 & 0.35 & 1.69 \\
\hline Operator 2 & 1 & 1 & 1 & 1 & 1 & 1 & 1 & 1 \\
\hline Dose Rate-mrem/hr & 0.02 & 0.02 & 0.13 & 0.02 & 0.13 & 2.02 & 2.13 & 10.13 \\
\hline Dose-person-mrem/MCO & 0.08 & 0.03 & 0.06 & 0.00 & 0.07 & 0.34 & $0 . \overline{35}$ & 1.69 \\
\hline \multicolumn{9}{|l|}{ Mgr } \\
\hline \multicolumn{9}{|l|}{ Dose Rate-mrem/hr } \\
\hline \multicolumn{9}{|l|}{ Dose-person-mrem/MCO } \\
\hline HPT & 1 & 1 & 1 & 1 & 1 & 1 & 1 & 1 \\
\hline Dose Rate-mrem/hr & 0.01 & 0.01 & 0.13 & 0.01 & 0.13 & 2.02 & 2.13 & 2.13 \\
\hline Dose-person-mrem $/ \mathrm{MCO}$ & 0.05 & 0.02 & 0.06 & 0.00 & 0.07 & 0.34 & 0.35 & 0.35 \\
\hline \multicolumn{9}{|l|}{ Truck Driver } \\
\hline \multicolumn{9}{|l|}{ Dose Rate-mrem/hr } \\
\hline \multicolumn{9}{|l|}{ Dose -person-mrem/MCO } \\
\hline Totals: & 0.21 & 0.08 & 0.19 & 0.01 & 0.22 & 0.67 & 1.06 & 3.73 \\
\hline \multicolumn{9}{|l|}{ Crew Dose: } \\
\hline \multicolumn{9}{|l|}{ Mask } \\
\hline \multicolumn{9}{|l|}{ SWP/shift } \\
\hline Operator 1 & 0.08 & 0.03 & 0.06 & 0.00 & 0.07 & & 0.35 & 1.69 \\
\hline Operator 2 & 0.08 & 0.03 & 0.06 & 0.00 & 0.07 & 0.34 & 0.35 & 1.69 \\
\hline \multicolumn{9}{|l|}{ Mgr } \\
\hline HPT & $0 . \overline{05}$ & 0.02 & 0,06 & 0.00 & 0.07 & 0.34 & 0.35 & 0.35 \\
\hline \multicolumn{9}{|l|}{ Truck Driver } \\
\hline Totals: & 0.21 & 0.08 & 0.19 & 0.01 & 0.22 & 0.67 & 1.06 & 3.73 \\
\hline
\end{tabular}


Table B-2. K West Basin Cask Loading System Personnel Doses. (sheet 5 of 6)

\begin{tabular}{|c|c|c|c|c|c|c|c|c|}
\hline Cask/MCO Handling & $\begin{array}{l}\text { Remove } \\
\text { lift slings } \\
\text { and beam } \\
\text { and store }\end{array}$ & $\begin{array}{c}\text { Decon } \\
\text { MCO } \\
\text { shield plug } \\
\text { and IP lid }\end{array}$ & $\begin{array}{c}\text { Clean } \\
\text { threads and } \\
\text { install } \\
\text { locking ring }\end{array}$ & $\begin{array}{l}\text { Deflate IP } \\
\text { lid seals } \\
\text { and } \\
\text { remove } \\
\text { bolts }\end{array}$ & $\begin{array}{l}\text { Remove } \\
\text { IP lid }\end{array}$ & $\begin{array}{c}\text { Adjust } \\
\text { cask water } \\
\text { level with } \\
\text { suction } \\
\text { tool }\end{array}$ & $\begin{array}{c}\text { Install } \\
\text { cask lid } \\
\text { and } \\
\text { torque } \\
\text { bolts }\end{array}$ & $\begin{array}{c}\text { Open cask } \\
\text { port cover } \\
\text { and adjust } \\
\text { gas } \\
\text { composition }\end{array}$ \\
\hline Location & $\begin{array}{l}\text { Loadout } \\
\text { Pit }\end{array}$ & $\begin{array}{l}\text { Loadout } \\
\text { Pit }\end{array}$ & Loadout Pit & $\begin{array}{l}\text { Loadout } \\
\text { Pit }\end{array}$ & $\begin{array}{l}\text { Loadout } \\
\text { Pit }\end{array}$ & $\begin{array}{l}\text { Loadout } \\
\text { Pit }\end{array}$ & $\begin{array}{c}\text { Loadout } \\
\text { Pit }\end{array}$ & Loadout Pit \\
\hline Background $\mathrm{mr} / \mathrm{hr}$ & 0.13 & $\begin{array}{r}0.13 \\
\end{array}$ & 0.13 & 0.13 & 0.13 & 0.13 & 0.13 & 0.13 \\
\hline $\begin{array}{l}\text { Standby Background } \\
\mathrm{mrem} / \mathrm{hr}\end{array}$ & 0.01 & 0.01 & 0.01 & 0.01 & 0.01 & 0.01 & 0.01 & 0.01 \\
\hline & & & & & & & & \\
\hline \multicolumn{9}{|l|}{ Dose Field } \\
\hline $30 \mathrm{~cm}$ & & & & & & & 0.2 & 0.2 \\
\hline one meter & 10 & 10 & 10 & 1.3 & 1.3 & 1.3 & 0.1 & 0.1 \\
\hline 3 meter & 2 & 2 & 2 & & & & & \\
\hline 5 meter & 0.8 & 0.8 & 0.8 & & & & & \\
\hline $\begin{array}{l}\text { Duration: Minutes in rad } \\
\text { zone }\end{array}$ & 20 & 15 & 85 & 35 & 25 & 15 & 85 & 35 \\
\hline Duration: Hours in rad zone & 0.33 & 0.25 & 1.42 & 0.58 & 0.42 & 0.25 & 1.42 & 0.58 \\
\hline $\begin{array}{l}\text { Duration: Hours of task, if } \\
\text { different }\end{array}$ & & & & 0.10 & 0.20 & & 0.50 & \\
\hline \multirow{2}{*}{\multicolumn{9}{|c|}{ Personnel: }} \\
\hline & & & & & & & & \\
\hline Operator 1 & 1 & 1 & 1 & 1 & 1 & 1 & 1 & 1 \\
\hline Dose Rate-mrem $/ \mathrm{hr}$ & 10.13 & 10.13 & 10.13 & 1.43 & 1.43 & 1.43 & 0.23 & 0.23 \\
\hline Dose-person-mrem/MCO & 3.38 & 2.53 & 14.34 & 0.83 & 0.59 & 0.36 & 0.32 & 0.13 \\
\hline Operator 2 & 1 & 1 & 1 & 1 & ] & 1 & 1 & 1 \\
\hline Dose Rate-mrem/hr & 10.13 & 10.13 & 10.13 & 1.43 & 1.43 & 1.43 & 0.23 & 0.23 \\
\hline Dose-person-mrem/MCO & 3.38 & 2.53 & 14.34 & 0.83 & 0.59 & 0.36 & 0.32 & 0.13 \\
\hline \multicolumn{9}{|l|}{ Mgr } \\
\hline \multicolumn{9}{|l|}{ Dose Rate-mrem $/ \mathrm{hr}$} \\
\hline \multicolumn{9}{|l|}{ Dose-person-mrem/MCO } \\
\hline $\mathrm{HPT}$ & 1 & 1 & 1 & 1 & 1 & 1 & 1 & 1 \\
\hline Dose Rate-mrem/hr & 10.13 & 10.13 & \begin{tabular}{l|l}
10.13 & \\
\end{tabular} & 1.43 & 1.43 & 1.43 & 0.23 & 0.23 \\
\hline Dose-person-mrem/MCO & 3.38 & 2.53 & 14.34 & 0.83 & 0.59 & 0.36 & 0.32 & 0.13 \\
\hline \multicolumn{9}{|l|}{ Truck Driver } \\
\hline \multicolumn{9}{|l|}{ Dose Rate-mrem/hr } \\
\hline \multicolumn{9}{|l|}{ Dose-person-mrem/MCO } \\
\hline Totals: & 10.13 & 7.59 & 43.03 & 2.49 & 1.78 & 1.07 & 0.96 & 0.39 \\
\hline \multicolumn{9}{|l|}{ Crew Dose: } \\
\hline \multicolumn{9}{|l|}{ Mask } \\
\hline \multicolumn{9}{|l|}{ SWP/shift } \\
\hline & & & & & & & & \\
\hline Operator 1 & 3.38 & 2.53 & 14.34 & 0.83 & 0.59 & 0.36 & 0.32 & 0.13 \\
\hline Operator 2 & 3.38 & 2.53 & 14.34 & 0.83 & 0.59 & 0.36 & 0.32 & 0.13 \\
\hline \multicolumn{9}{|l|}{$\mathrm{Mgr}$} \\
\hline HPT & 3.38 & 2.53 & 14.34 & 0.83 & 0.59 & 0.36 & 0.32 & 0.13 \\
\hline \multicolumn{9}{|l|}{ Truck Driver } \\
\hline Totals: & 10.13 & 7.59 & 43.03 & 2.49 & 1.78 & 1.07 & 0.96 & 0.39 \\
\hline
\end{tabular}


Table B-2. K West Basin Cask Loading System Personnel Doses. (sheet 6 of 6)

\begin{tabular}{|c|c|c|c|c|c|c|c|c|}
\hline Cask/MCO Handling & $\begin{array}{c}\text { Attach } \\
\text { crane to } \\
\text { cask and } \\
\text { raise from } \\
\text { IP }\end{array}$ & $\begin{array}{c}\text { Dry, } \\
\text { survey and } \\
\text { smear cask } \\
\text { surface }\end{array}$ & $\begin{array}{c}\text { Move cask } \\
\text { and tiedown } \\
\text { on trailer }\end{array}$ & $\begin{array}{l}\text { Connect } \\
\text { tractor to } \\
\text { trailer }\end{array}$ & $\begin{array}{c}\text { Perform } \\
\text { final } \\
\text { radiation } \\
\text { survey }\end{array}$ & $\begin{array}{l}\text { Release } \\
\text { cask for } \\
\text { transfer to } \\
\text { CVD }\end{array}$ & $\begin{array}{l}\text { Drive } \\
\text { trailer } \\
\text { away }\end{array}$ & $\begin{array}{c}\text { Total } \\
\text { (per } \mathrm{MCO})\end{array}$ \\
\hline Location & $\begin{array}{l}\text { Loadout } \\
\text { Pit }\end{array}$ & $\begin{array}{c}\text { Truck } \\
\text { Loading }\end{array}$ & $\begin{array}{c}\text { Truck } \\
\text { Loading }\end{array}$ & $\begin{array}{c}\text { Truck } \\
\text { Loading }\end{array}$ & \begin{tabular}{c|} 
Truck \\
Loading \\
\end{tabular} & $\begin{array}{c}\text { Truck } \\
\text { Loading }\end{array}$ & $\begin{array}{c}\text { Truck } \\
\text { Loading }\end{array}$ & \\
\hline Background $\mathrm{mr} / \mathrm{hr}$ & 0.13 & 0.02 & 0.02 & 0.02 & \begin{tabular}{|r|}
0.02 \\
\end{tabular} & 0.02 & 0.02 & \\
\hline $\begin{array}{l}\text { Standby Background } \\
\mathrm{mrem} / \mathrm{hr}\end{array}$ & 0.01 & 0.01 & 0.01 & 0.01 & 0.01 & 0.01 & 0.01 & \\
\hline \multicolumn{9}{|l|}{ Dose Field } \\
\hline \multicolumn{9}{|l|}{$30 \mathrm{~cm}}$. \\
\hline one meter & 7 & 7 & 7 & 7 & 7 & 7 & 7 & \\
\hline 3 meter & 3.5 & 3.5 & 3.5 & 3.5 & 3.5 & 3.5 & 3.5 & \\
\hline 5 meter & 0.9 & 0.9 & 0.9 & 0.9 & 0.9 & 0.9 & 0.9 & \\
\hline $\begin{array}{l}\text { Duration: Minutes in rad } \\
\text { zone }\end{array}$ & 20 & 105 & 60 & 45 & 20 & 5 & 5 . & \\
\hline Duration: Hours in rad zone & 0.33 & 1.75 & 1.00 & 0.75 & 0.33 & 0.08 & 0.08 & 28.58 \\
\hline \multicolumn{9}{|l|}{$\begin{array}{l}\text { Duration: Hours of task, if } \\
\text { different }\end{array}$} \\
\hline \multicolumn{9}{|l|}{ Personnel: } \\
\hline Operator 1 & 1 & 1 & 1 & 1 & 1 & 1 & 1 & \\
\hline Dose Rate-mrem/hr & 3.63 & 7.02 & 7.02 & 3.52 & 3.52 & 0.92 & 0.92 & \\
\hline Dose-person-mrem/MCO & 1.21 & 12.28 & 7.02 & 2.64 & 1.17 & 0.08 & 0.08 & 49.87 \\
\hline Operator 2 & 1 & 1 & 1 & & 1 & 1 & & \\
\hline Dose Rate-mrem/hr & 0.01 & 3.52 & 7.02 & 3.52 & 3.52 & 0.92 & 7.02 & \\
\hline Dose-person-mrem/MCO & 0.00 & 6.15 & 7.02 & & 1.17 & 0.08 & & 40.13 \\
\hline \multicolumn{9}{|l|}{ Mgr } \\
\hline \multicolumn{9}{|l|}{ Dose Rate-mrem $/ \mathrm{hr}$} \\
\hline Dose-person-mrem/MCO & & & & & & & & 0.25 \\
\hline HPT & 1 & 1 & 1 & 1 & 1 & 1 & 1 & \\
\hline Dose Rate-mrem $/ \mathrm{hr}$ & 7.13 & 7.02 & 3.52 & 3.52 & \begin{tabular}{l|l|l}
7.02 \\
\end{tabular} & 0.02 & 0.02 & \\
\hline Dose-person-mrem/MCO & 2.38 & 12.28 & 3.52 & 2.64 & 2.34 & 0.00 & 0.00 & 47.49 \\
\hline Truck Driver & & & & 1 & & 1 & 1 & \\
\hline Dose Rate-mrem/hr & & & & 3.51 & & 0.91 & 0.91 & \\
\hline Dose-person-mrem/MCO & & & & 2.63 & & 0.08 & 0.08 & 2.79 \\
\hline Totals: & 3.59 & 30.71 & 17.55 & 7.91 & 4.68 & 0.23 & 0.15 & 140.54 \\
\hline \multicolumn{9}{|l|}{ Crew Dose: } \\
\hline \multicolumn{9}{|l|}{ Mask } \\
\hline \multicolumn{9}{|l|}{ SWP/shift } \\
\hline Onerator 1 & 3.63 & 1228 & 7.02 & 2.64 & 1.17 & 0.08 & 0.08 & 49.87 \\
\hline Operator 2 & 0.00 & 6.15 & 7.02 & & 1.17 & 0.08 & & 40.13 \\
\hline Mgr & & & & & & & & 0.25 \\
\hline HPT & 2.39 & 12.28 & 3.52 & 2.64 & 2.34 & 0.00 & 0.00 & $\overline{47.49}$ \\
\hline Truck Driver & & & & 2.63 & & 0.08 & 0.08 & 2.79 \\
\hline
\end{tabular}


SNF-4977 REV 0

This page intentionally left blank. 
SNF-4977 REV 0

APPENDIX C

COMPUTATION OF PERSONNEL DOSES DURING INTEGRATED WATER TREATMENT SYSTEM OPERATIONS 
SNF-4977 REV 0

This page intentionally left blank. 


\section{APPENDIX C \\ COMPUTATION OF PERSONNEL DOSES DURING INTEGRATED WATER TREATMENT SYSTEM OPERATIONS}

Table C-1 contains a listing of the spreadsheet used to compute the K West Basin Integrated Water Treatment System (IWTS) personnel doses given in Table 5-3 for all activities but the ion exchange module changeout. Dose computations in Table C-1 are as follows:

$\{$ annual dose per person per activity $\}=\{\text { worker dose rate }\}^{*}\{\text { frequency }\}^{*}\{$ duration $\}$

where worker dose rates (background + IWTS component) are in mrem/h; duration (hours) is the activity time; doses are in mrem; and frequency is the number of times the activity is performed per year. The $\mathrm{K}$ Basin background dose rates that a worker receives for a particular activity are based on data in Tables 4-1 and 4-6. The dose rate from the IWTS ion exchange modules are based on data in Tables 4-5 and 4-6.

Table C-1. Integrated Water Treatment System Personnel

Doses for All Activities Except IXM Changeout

\begin{tabular}{|c|c|c|c|c|c|c|c|}
\hline \multirow{2}{*}{$\begin{array}{c}\text { K West Basin IWTS } \\
\text { Activity }\end{array}$} & \multirow{2}{*}{$\begin{array}{c}\text { Time } \\
(\min .)\end{array}$} & \multirow[b]{2}{*}{ Frequency } & \multirow{2}{*}{$\begin{array}{l}\text { Frequency } \\
(\# \text { per yr) }\end{array}$} & \multicolumn{2}{|c|}{ Dose Rate $(\mathrm{mrem} / \mathrm{h})$} & \multirow{2}{*}{$\begin{array}{c}\text { Dose } \\
(\mathrm{mrem} / \mathrm{y})\end{array}$} & \multirow{2}{*}{$\begin{array}{c}\text { Dose } \\
\text { (Total) }\end{array}$} \\
\hline & & & & Background & $\begin{array}{c}\text { IWTS } \\
\text { Comps. }\end{array}$ & & \\
\hline $\begin{array}{l}\text { Routine } \\
\text { inspection/tour }\end{array}$ & 15 & $2 /$ day & 500 & 0.017 & & 2.1 & 4.7 \\
\hline Sample collection ${ }^{\mathrm{c}}$ & 20 & $3 / \mathrm{wk}$ & 156 & 0.017 & 4.6 & 240.1 & 528.2 \\
\hline Filter purge $\mathrm{e}^{\mathrm{b}, \mathrm{d}}$ & 15 & $<1 / \mathrm{mo}$ & 12 & 0.017 & 1.5 & 4.6 & 10.0 \\
\hline Operator Total & & & & & & 246.8 & 542.9 \\
\hline HPT Total & & & & & & 240.1 & 528.2 \\
\hline Total & & & & & & 486.9 & $1,071.1$ \\
\hline
\end{tabular}

${ }^{a}$ Assumes that IWTS operations are carried out 250 days/year.

bone operator is required to carry out these activities.

${ }^{\circ}$ One operator and one HPT are required for this activity.

${ }^{\mathrm{d}}$ Data for the infrequently-used air scrub only. Other techniques are accomplished remotely with no personnel dose incurred.

HPT $=$ health physics technician

Listed in Table C-2 is the spreadsheet (Bullock 1999) used to compute doses to personnel involved in K West Basin IWTS IXM change-outs. Dose computations in the spreadsheet are as follows: 
Table C-2. Personnel Doses from a Change-out of an Ion Exchange Module in the K West Basin Integrated Water Treatment System. (sheet 1 of 3)

\begin{tabular}{|c|c|c|c|c|c|c|c|c|}
\hline IXM Changeout & Drain IXM & & Disconnect & & & & Critical lift & \\
\hline & $\begin{array}{l}\text { Valve out } \\
\text { and drain } \\
\text { IXM }\end{array}$ & $\begin{array}{c}\text { Prepare } \\
\text { work area }\end{array}$ & $\begin{array}{c}\text { Disconnect } \\
\text { outlet hose, } \\
\text { remove } 3 \\
\text { inch pipe, } \\
\text { install cap } \\
\text { and plug }\end{array}$ & $\begin{array}{c}\text { Disconnect } \\
\text { inlet hose, } \\
\text { remove } 3 \\
\text { inch pipe, } \\
\text { install cap } \\
\text { and plug }\end{array}$ & $\begin{array}{l}\text { Disconnect } \\
\text { vent tree } \\
\text { and store. }\end{array}$ & $\begin{array}{c}\text { Rad } \\
\text { survey of } \\
\text { IXM and } \\
\text { decon }\end{array}$ & $\begin{array}{l}\text { Attach } \\
\text { rigging to } \\
\text { IXM, } \\
\text { move to } \\
\text { temp } \\
\text { storage } \\
\text { area }\end{array}$ & $\begin{array}{c}\text { Rad } \\
\text { survey of } \\
\text { IXM }\end{array}$ \\
\hline Location & $\begin{array}{c}\text { Transfer } \\
\text { area }\end{array}$ & $\begin{array}{c}\text { Transfer } \\
\text { area }\end{array}$ & $\begin{array}{c}\text { Transfer } \\
\text { area }\end{array}$ & $\begin{array}{c}\text { Transfer } \\
\text { area }\end{array}$ & $\begin{array}{c}\text { Transfer } \\
\text { area }\end{array}$ & $\begin{array}{c}\text { Transfer } \\
\text { area }\end{array}$ & $\begin{array}{l}\text { Transfer } \\
\text { area }\end{array}$ & $\begin{array}{c}\text { Transfer } \\
\text { area }\end{array}$ \\
\hline Background $\mathrm{mr} / \mathrm{hr}$ & 0.02 & 0.02 & 0.02 & 0.02 & 0.02 & 0.02 & 0.02 & 0.02 \\
\hline Standby Background mrem $/ \mathrm{hr}$ & 0.01 & 0.01 & 0.01 & 0.01 & 0.01 & 0.01 & 0.01 & 0.01 \\
\hline & & & & & & & & \\
\hline \multicolumn{9}{|l|}{ Dose Field } \\
\hline $30 \mathrm{~cm}$ & 20 & 20 & 20 & 1.5 & 1.5 & 10 & 1.5 & 10 \\
\hline $1 \mathrm{~m}$ & & & 6 & & & & & \\
\hline Duration: Min. in rad zone & 15 & 10 & 20 & 15 & 10 & 20 & 30 & 10 \\
\hline Duration: hrs. in rad zone & 0.25 & 0.17 & 0.33 & 0.25 & 0.17 & 0.33 & 0.50 & 0.17 \\
\hline \multicolumn{9}{|l|}{$\begin{array}{l}\text { Duration: hrs of task, if } \\
\text { different }\end{array}$} \\
\hline & & & & & & & & \\
\hline \multicolumn{9}{|l|}{ Personnel: } \\
\hline Operator 1 & 1 & 1 & 1 & 1 & 1 & 1 & 1 & 1 \\
\hline Dose Rate-mrem/hr & 20.02 & 20.02 & 6.02 & 0.02 & 0.02 & 0.01 & 0.01 & 0.01 \\
\hline Dose-person-mrem & 5.00 & 3.34 & 2.01 & 0.00 & 0.00 & 0.00 & 0.01 & 0.00 \\
\hline Riggers & & & & & & & 2 & \\
\hline Dose Rate-mrem $/ \mathrm{hr}$ & & & & & & & 1.52 & \\
\hline Dose-person-mrem & & & & & & & 1.52 & \\
\hline $\mathrm{Mgr}$ & & & 1 & 1 & 1 & 1 & 1 & 1 \\
\hline Dose Rate-mrem/hr & & & 0.01 & 0.01 & 0.01 & 0.01 & 0.01 & 0.01 \\
\hline Dose-person-mrem & & & 0.00 & 0.00 & 0.00 & 0.00 & 0.01 & 0.00 \\
\hline HPT & 1 & 1 & 1 & 1 & 1 & 1 & 1 & 1 \\
\hline Dose Rate-mrem $/ \mathrm{hr}$ & 20.02 & 20.02 & 6.02 & 1.52 & 1.52 & 10.02 & 0.01 & 10.02 \\
\hline Dose-person-mrem & 5.00 & 3.34 & 2.01 & 0.38 & 0.25 & 3.34 & 0.01 & 1.67 \\
\hline Pipefitter & & & 2 & 2 & 2 & & & \\
\hline Dose Rate-mrem/hr & & & 20.02 & 1.52 & 1.52 & & & \\
\hline Dose-person-mrem & & & 13.34 & 0.76 & 0.51 & & & \\
\hline Totals: & 0.00 & 0.01 & 17.36 & 1.14 & 0.76 & 3.35 & 1.53 & 1.67 \\
\hline \multicolumn{9}{|l|}{ Crew Dose: } \\
\hline \multicolumn{9}{|l|}{ Mask } \\
\hline \multicolumn{9}{|l|}{ SWP/shift } \\
\hline Operator 1 & 5.00 & 3.34 & 2.01 & 0.00 & 0.00 & 0.00 & 0.01 & 0.00 \\
\hline Riggers & & & & & & & 1.52 & \\
\hline $\mathrm{Mgr}$ & & & 0.00 & 0.00 & 0.00 & 0.00 & 0.01 & 0.00 \\
\hline HPT & 5.00 & 3.34 & 2.01 & 0.38 & 0.25 & 3.34 & 0.01 & 1.67 \\
\hline Pipefitter & & & 13.34 & 0.76 & 0.51 & & & \\
\hline Totals: & 10.01 & 6.67 & 17.36 & 1.14 & 0.76 & 3.35 & 1.53 & \\
\hline
\end{tabular}


Table C-2. Personnel Doses from a Change-out of an Ion Exchange Module in the $\mathrm{K}$ West Basin Integrated Water Treatment System. (sheet 2 of 3)

\begin{tabular}{|c|c|c|c|c|c|c|c|c|}
\hline IXM Changeout & & & & $\begin{array}{l}\text { Connect } \\
\text { IXM }\end{array}$ & & & & \\
\hline & $\begin{array}{l}\text { Move new } \\
\text { IXM into } \\
\text { position }\end{array}$ & $\begin{array}{l}\text { Attach } \\
\text { rigging to } \\
\text { IXM, } \\
\text { move to } \\
\text { trailer, tie } \\
\text { down }\end{array}$ & \begin{tabular}{|c|} 
Attach \\
tractor and \\
remove \\
from \\
transfer \\
area \\
\end{tabular} & $\begin{array}{c}\text { Prepare } \\
\text { work area }\end{array}$ & $\begin{array}{c}\text { Remove } \\
\text { plug, } \\
\text { connect } \\
\text { pipe and } \\
\text { hose to } \\
\text { new inlet. }\end{array}$ & $\begin{array}{c}\text { Remove } \\
\text { plug, } \\
\text { connect } \\
\text { pipe and } \\
\text { hose to } \\
\text { new outlet. }\end{array}$ & $\begin{array}{c}\text { Connect } \\
\text { vent tree to } \\
\text { top of IXM }\end{array}$ & $\begin{array}{c}\text { Rad survey } \\
\text { of area and } \\
\text { decon }\end{array}$ \\
\hline Location & $\begin{array}{c}\text { Transfer } \\
\text { area }\end{array}$ & $\begin{array}{c}\text { Transfer } \\
\text { area }\end{array}$ & \begin{tabular}{|c|}
$\begin{array}{c}\text { Transfer } \\
\text { area }\end{array}$ \\
\end{tabular} & $\begin{array}{c}\text { Transfer } \\
\text { area }\end{array}$ & $\begin{array}{c}\text { Transfer } \\
\text { area }\end{array}$ & $\begin{array}{c}\text { Transfer } \\
\text { area }\end{array}$ & $\begin{array}{c}\text { Transfer } \\
\text { area }\end{array}$ & $\begin{array}{l}\text { Transfer } \\
\text { area }\end{array}$ \\
\hline Background $\mathrm{mr} / \mathrm{hr}$ & 0.02 & 0.02 & 0.02 & 0.02 & 0.02 & 0.02 & 0.02 & 0.02 \\
\hline Standby Background mrem $/ \mathrm{hr}$ & 0.01 & 0.01 & 0.01 & 0.01 & 0.01 & 0.01 & 0.01 & 0.01 \\
\hline & & & & & & & & \\
\hline \multicolumn{9}{|l|}{ Dose Field } \\
\hline $30 \mathrm{~cm}$. & 10 & 1.5 & 10 & & & & & \\
\hline \multicolumn{9}{|l|}{$1 \mathrm{~m}$} \\
\hline Duration: Min, in rad zone & 20 & 30 & 10 & 10 & 10 & 20 & 15 & 10 \\
\hline Duration: hrs. in rad zone & 0.33 & 0.50 & 0.17 & 0.17 & 0.17 & 0.33 & 0.25 & 0.17 \\
\hline \multicolumn{9}{|l|}{$\begin{array}{l}\text { Duration: hrs of task, if } \\
\text { different }\end{array}$} \\
\hline & & & & & & & & \\
\hline \multicolumn{9}{|l|}{ Personnel: } \\
\hline Operator 1 & 1 & 1 & 1 & 1 & 1 & 1 & 1 & 1 \\
\hline Dose Rate-mrem $/ \mathrm{hr}$ & 0.01 & 0.01 & 0.01 & 0.02 & 0.02 & 0.02 & 0.02 & 0.02 \\
\hline Dose-person-mrem & 0.00 & 0.01 & 0.00 & 0.00 & 0.00 & 0.01 & 0.00 & 0.00 \\
\hline Riggers & 2 & 2 & & & & & & \\
\hline Dose Rate-mrem/hr & 10.02 & 1.52 & & & & & & \\
\hline Dose-person-mrem & 6.68 & 1.52 & & & & & & \\
\hline Mgr & 1 & 1 & 1 & 1 & 1 & 1 & 1 & 1 \\
\hline Dose Rate-mrem $/ \mathrm{hr}$ & 0.01 & 0.01 & 0.01 & 0.01 & 0.01 & 0.01 & 0.01 & 0.01 \\
\hline Dose-person-mrem & 0.00 & 0.01 & 0.00 & 0.00 & 0.00 & 0.00 & 0.00 & 0.00 \\
\hline HPT & 1 & 1 & 1 & 1 & 1 & 1 & 1 & 1 \\
\hline Dose Rate-mrem/hr & 0.02 & 0.01 & 0.01 & 0.01 & 0.02 & 0.02 & 0.02 & 0.02 \\
\hline Dose-person-mrem & 0.01 & 0.01 & 0.00 & 0.00 & 0.00 & 0.01 & 0.00 & 0.00 \\
\hline Pipefitter & & & & & 2 & 2 & 2 & \\
\hline Dose Rate-mrem/hr & & & & & 0.02 & 0.02 & 0.02 & \\
\hline Dose-person-mrem & & & & & 0.01 & 0.01 & 0.01 & \\
\hline Totals: & 6.69 & 1.53 & 0.01 & 0.01 & 0.01 & 0.03 & 0.02 & 0.01 \\
\hline \multicolumn{9}{|l|}{ Crew Dose: } \\
\hline \multicolumn{9}{|l|}{ Mask } \\
\hline \multicolumn{9}{|l|}{ SWP/shift } \\
\hline Operator 1 & 0.00 & 0.01 & 0.00 & 0.00 & 0.00 & 0.01 & 0.00 & 0.00 \\
\hline Riggers & 6.68 & 1.52 & & & & & & \\
\hline Mgr & 0.00 & 0.01 & 0.00 & 0.00 & 0.00 & 0.00 & 0.00 & 0.00 \\
\hline HPT & 0.01 & 0.01 & 0.00 & 0.00 & 0.00 & 0.01 & 0.00 & 0.00 \\
\hline Pipefitter & & & & & 0.01 & 0.01 & 0.01 & \\
\hline Totals: & 6.69 & 1.53 & 0.01 & 0.01 & 0.01 & 0.03 & 0.02 & 0.01 \\
\hline
\end{tabular}




\section{SNF-4977 REV 0}

Table C-2. Personnel Doses from a Change-out of an Ion Exchange Module in the K West Basin Integrated Water Treatment System. (sheet 3 of 3 )

\begin{tabular}{|c|c|c|}
\hline \multicolumn{3}{|l|}{ IXM Changeout } \\
\hline & Fill and vent new IXM & Total \\
\hline Location & Transfer area & \\
\hline Background $\mathrm{mr} / \mathrm{hr}$ & 0.02 & \\
\hline Standby Background mrem $/ \mathrm{hr}$ & 0.01 & \\
\hline & & \\
\hline \multirow{2}{*}{\multicolumn{3}{|c|}{ Dose Field }} \\
\hline & & \\
\hline \multicolumn{3}{|l|}{$30 \mathrm{~cm}$} \\
\hline \multicolumn{3}{|l|}{$1 \mathrm{~m}$} \\
\hline Duration: Min. in rad zone & 35 & \\
\hline Duration: hrs. in rad zone & 0.58 & 4.83 \\
\hline \multicolumn{3}{|l|}{$\begin{array}{l}\text { Duration: hrs of task, if } \\
\text { different }\end{array}$} \\
\hline & & \\
\hline \multicolumn{3}{|l|}{ Personnel: } \\
\hline Operator 1 & 1 & \\
\hline Dose Rate-mrem $/ \mathrm{hr}$ & 0.02 & 1 \\
\hline Dose-person-mrem & 0.01 & 10.40 \\
\hline \multicolumn{3}{|l|}{ Riggers } \\
\hline Dose Rate-mrem $/ \mathrm{hr}$ & & 2 \\
\hline Dose-person-mrem & & 9.71 \\
\hline Mgr & 1 & \\
\hline Dose Rate-mrem $/ \mathrm{hr}$ & 0.01 & 1 \\
\hline Dose-person-mrem & 0.01 & 0.04 \\
\hline \multicolumn{3}{|l|}{ HPT } \\
\hline Dose Rate-mrem/hr & & 1 \\
\hline Dose-person-mrem & & 16.02 \\
\hline \multicolumn{3}{|l|}{ Pipefitter } \\
\hline Dose Rate-mrem $/ \mathrm{hr}$ & & 2 \\
\hline Dose-person-mrem & & 14.63 \\
\hline Totals: & 0.02 & 34.14 \\
\hline \multicolumn{3}{|l|}{ Crew Dose: } \\
\hline \multicolumn{3}{|l|}{ Mask } \\
\hline \multicolumn{3}{|l|}{ SWP/shift } \\
\hline Operator 1 & 0.01 & 10.40 \\
\hline Riggers & & 9.71 \\
\hline Mgr & 0.01 & 0.04 \\
\hline HPT & & 16.02 \\
\hline Pipefitter & & 14.63 \\
\hline Totals: & 0.02 & 50.81 \\
\hline
\end{tabular}

IXM $=$ ion exchange module.

Mgr = person-in-charge.

HPT $=$ health physics technician. 


$$
\begin{aligned}
& \{\text { worker dose rate }\}=\{\mathrm{K} \text { Basin background }\}+\{\text { dose from IXMs }\} \\
& \{\text { dose-person }\}=\{\text { no. of workers }\}^{*}\{\text { worker dose rate }\}^{*}\{\text { duration }\}
\end{aligned}
$$

where dose rate is in $\mathrm{mrem} / \mathrm{h}$; duration is in hours; doses are in $\mathrm{mrem} /$ changeout; and a worker is either a person-in-charge (mgr in spreadsheet), an operator (operator 1 in spreadsheet), a health physics technician (HPT in spreadsheet), a rigger, or a pipefitter. The K Basin background dose rate that each worker receives for a particular activity (listed as background or standby background in Table C-2) is defined in Tables 4-6 and 4-1. The IXM dose rate that each worker receives for a particular activity is one of the two dose rates listed in the spreadsheet under "Dose Field." Table 4-6 identifies which of the two applies. The total dose per changeout for each worker category listed in the last column of the spreadsheet in Table C-2 is the sum of the doses listed in column 2 through the second-to-last column.

The total doses in Table C-2 are for a single IXM change-out. IWTS operations personnel anticipate about 50 change-outs per year. Table C-3 is a listing of a spreadsheet used to compute annual and project lifetime doses from the total doses per change-out in Table C-2. Lifetime doses in Table C-3 assume a 2.2-year period of IWTS operation.

The doses shown in Table 5-3 are the sum of data in Tables C-1 and C-3.

Table C-3. Annual and Lifetime Doses from Changeout of Ion Exchange Modules in the K West Basin Integrated Water Treatment System.

\begin{tabular}{|l|c|c|c|}
\hline \multirow{2}{*}{ Worker } & \multicolumn{3}{|c|}{ Dose (mrem) } \\
\cline { 2 - 4 } & Single IXM & Annual $^{\mathrm{a}}$ & Lifetime $^{\mathrm{c}}$ \\
\hline Operator & 10.40 & 520.1 & 1144.2 \\
\hline Riggers & 9.71 & 485.6 & 1068.3 \\
\hline PIC & 0.04 & 2.2 & 4.9 \\
\hline HPT & 16.02 & 801.1 & 1762.3 \\
\hline Pipefitters & 14.63 & 731.7 & 1609.8 \\
\hline Totals & 50.81 & 2540.7 & 5589.5 \\
\hline
\end{tabular}

${ }^{\mathrm{a}}$ The source of doses for a single IXM change-out is spreadsheet (Bullock 1999) listed in Table C-2.

${ }^{\mathrm{b}}$ Annual doses were computed assuming 50 IXM replacements per year.

${ }^{\mathrm{c}}$ Lifetime doses assume an operating period of 2.2 years.

HPT $=$ health physics technician.

IXM = ion exchange module.

$\mathrm{PIC}=$ person-in-charge.

\section{REFERENCE}

Bullock, D. E., 1999, Ion Exchange Module Replacement Spreadsheets, August 26, Fluor Daniel Hanford Incorporated, Richland, Washington. 
SNF-4977 REV 0

This page intentionally left blank. 


\section{SNF-4977 REV 0}

This page intentionally left blank. 


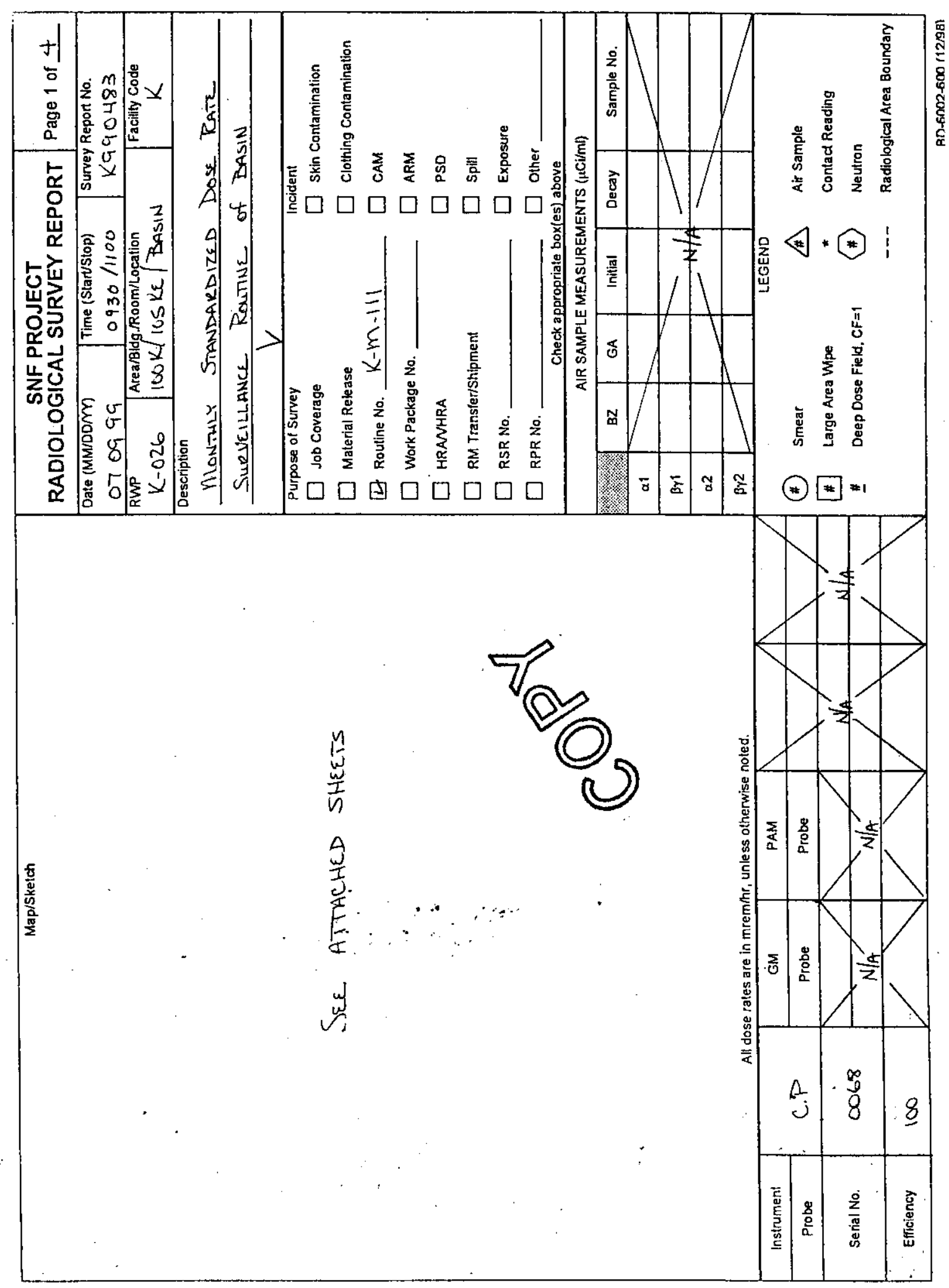




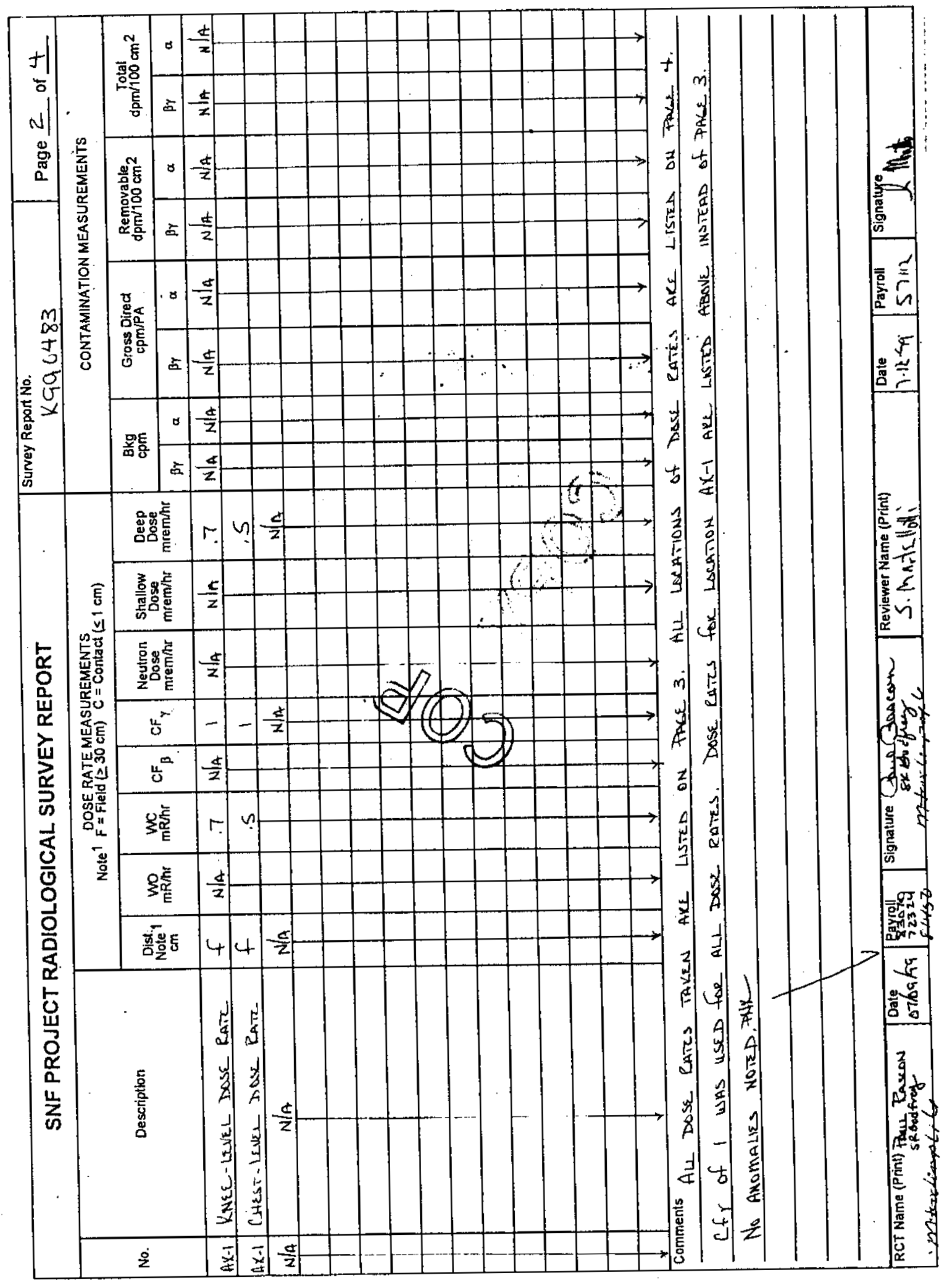




\begin{tabular}{|c|c|c|c|c|c|}
\hline \multicolumn{6}{|c|}{ STANDARDIZED DOSE RATE ${ }^{1}$ SURVEILLANCE } \\
\hline $\begin{array}{l}\text { Facility } \\
105 \mathrm{KE}\end{array}$ & otlogkig & $\begin{array}{l}\text { Basin Water Level } \\
16 \text { th. } 10^{3 / 4} \text { in. }\end{array}$ & \multicolumn{2}{|c|}{$\begin{array}{l}\text { Survey Report No. } \\
\text { K990483 }\end{array}$} & Page 3 of 4 \\
\hline \multicolumn{2}{|c|}{ Location No. } & \multicolumn{2}{|c|}{ Knee-Level Dose Rate ${ }^{2}$} & \multicolumn{2}{|c|}{ Chest-Level Dose Rate ${ }^{3}$} \\
\hline \multicolumn{2}{|c|}{$\mathrm{AU}-5$} & \multicolumn{2}{|l|}{5} & \multicolumn{2}{|c|}{4.6} \\
\hline \multicolumn{2}{|c|}{ AW-9 } & \multicolumn{2}{|l|}{3.4} & \multicolumn{2}{|c|}{5} \\
\hline \multicolumn{2}{|c|}{$A X-12$} & \multicolumn{2}{|l|}{6} & \multicolumn{2}{|c|}{6} \\
\hline \multicolumn{2}{|c|}{ AT-19 } & \multicolumn{2}{|l|}{.5} & \multicolumn{2}{|c|}{.5} \\
\hline \multicolumn{2}{|c|}{ Cubicle 1307} & \multicolumn{2}{|l|}{2.3} & \multicolumn{2}{|c|}{2.3} \\
\hline \multicolumn{2}{|c|}{ Cubicle 1339} & \multicolumn{2}{|l|}{1.4} & \multicolumn{2}{|c|}{1.4} \\
\hline \multicolumn{2}{|c|}{ Cubicle 1472} & \multicolumn{2}{|l|}{3.7} & \multicolumn{2}{|c|}{2} \\
\hline \multicolumn{2}{|c|}{ Cubicle 3772} & \multicolumn{2}{|l|}{4.25} & \multicolumn{2}{|c|}{2.2} \\
\hline \multicolumn{2}{|c|}{ Cubicle 3639} & 1.2 & & & \\
\hline Cubicle & 607 & 2 & & & \\
\hline Cubicle & 707 & 2.2 & & & \\
\hline Cubicle & 73839 & 1.4 & & & \\
\hline Cubicle & 872 & 3.3 & & & \\
\hline 0 & & 3.2 & & & \\
\hline O- & & 6 & & & \\
\hline $\mathrm{N}-$ & & $\therefore 1.8$ & 5 & & \\
\hline $\mathrm{N}-$ & & .6 & & & \\
\hline $1-$ & & .7 & & & \\
\hline $1-$ & & 3 & & & \\
\hline $\mathrm{I}-1$ & & 1 & & & \\
\hline $1-1$ & & 1.4 & & & \\
\hline
\end{tabular}




\section{SNF-4977 REV 0}

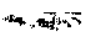

\begin{tabular}{|l|l|l|}
\hline 105KE Standardized Dose Rate Locations & $\begin{array}{c}\text { Survey Report No. } \\
\text { K990483 }\end{array}$ & Page 4 of 4 \\
\hline
\end{tabular}

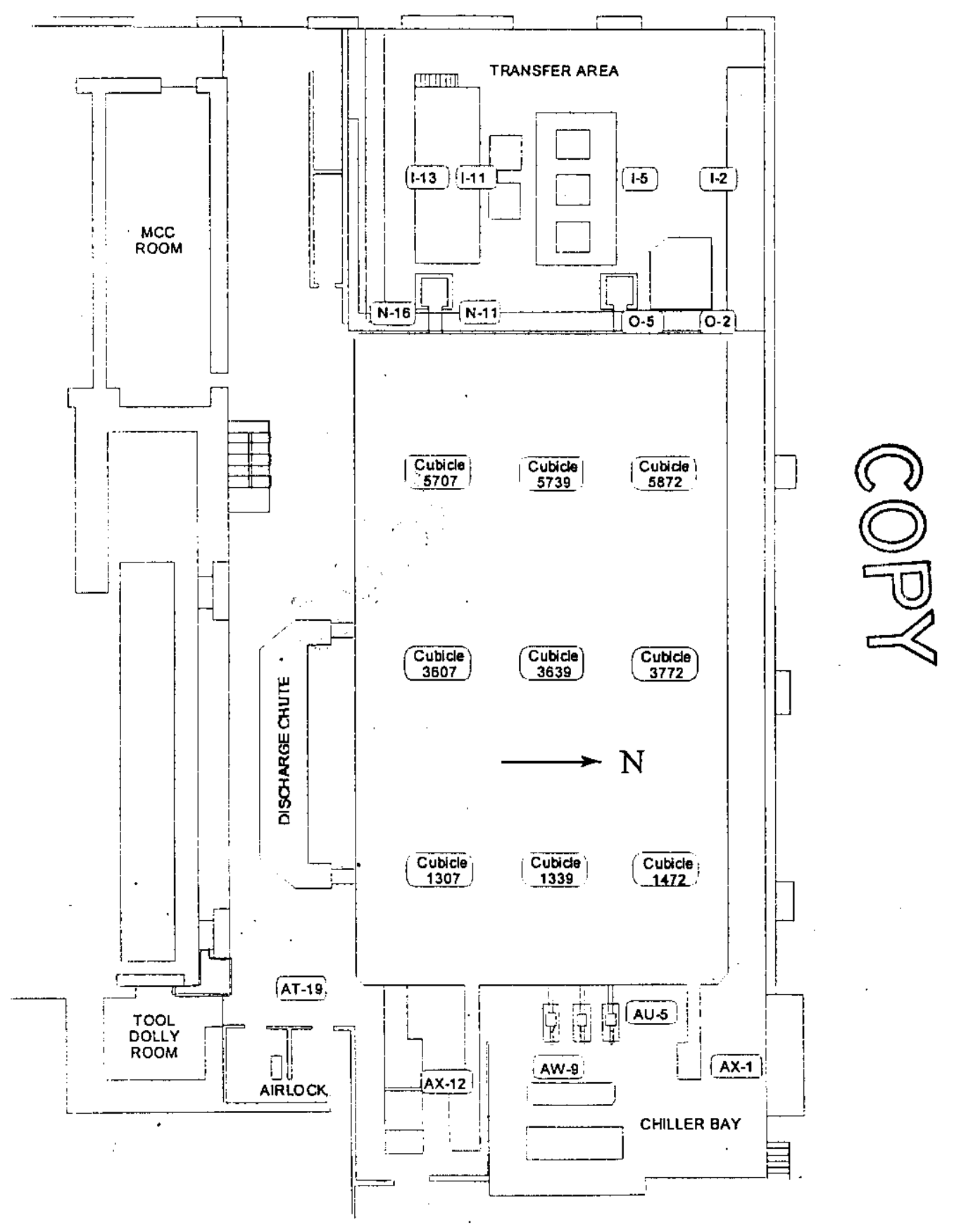


SNF-4977 REV 0

\section{APPENDIX E}

MONTHLY STANDARDIZED DOSE RATE SURVEY

FOR K WEST BASIN SURVEY NO. L990899 


\section{SNF-4977 REV 0}

This page intentionally left blank. 
SNF-4977 REV 0

F.

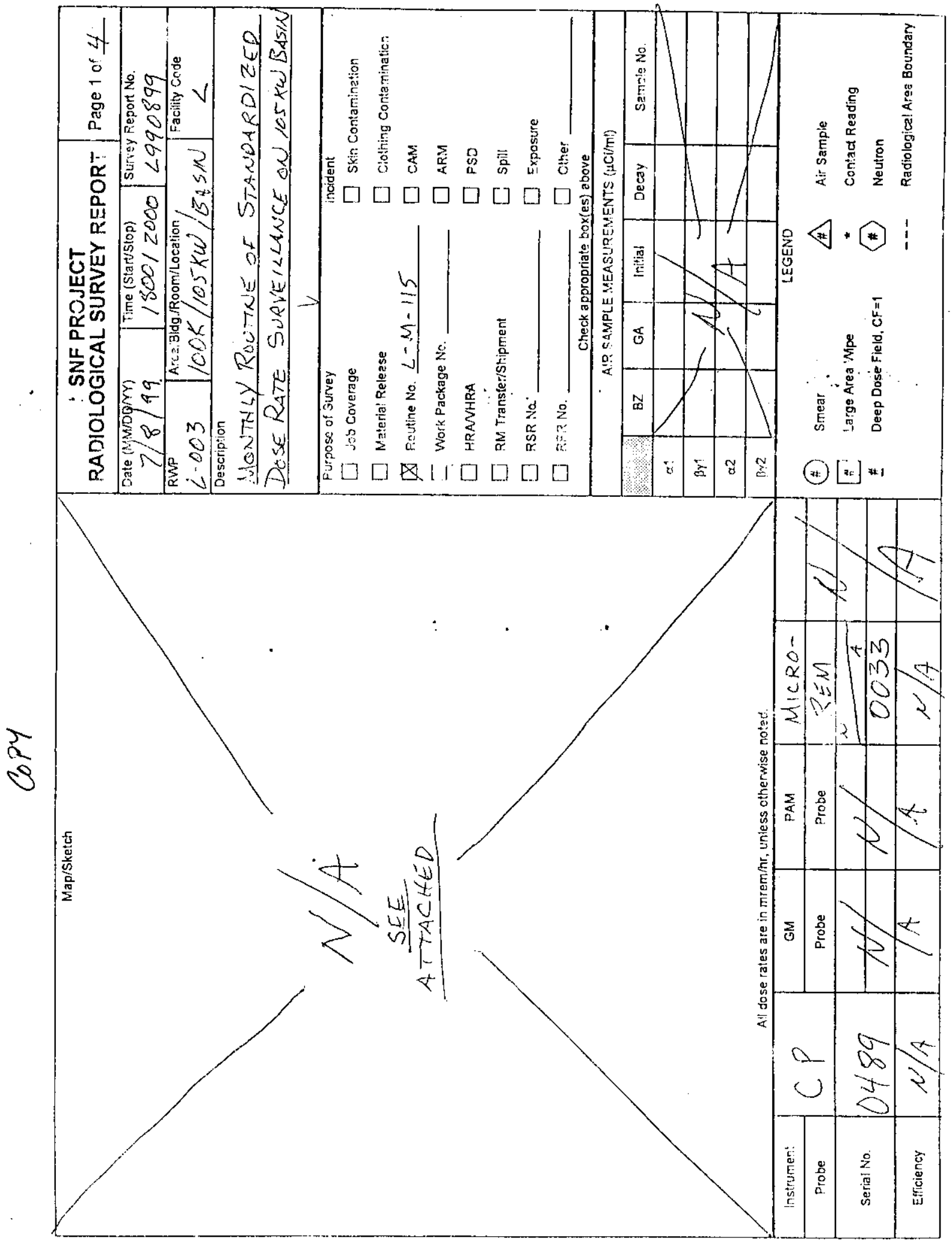




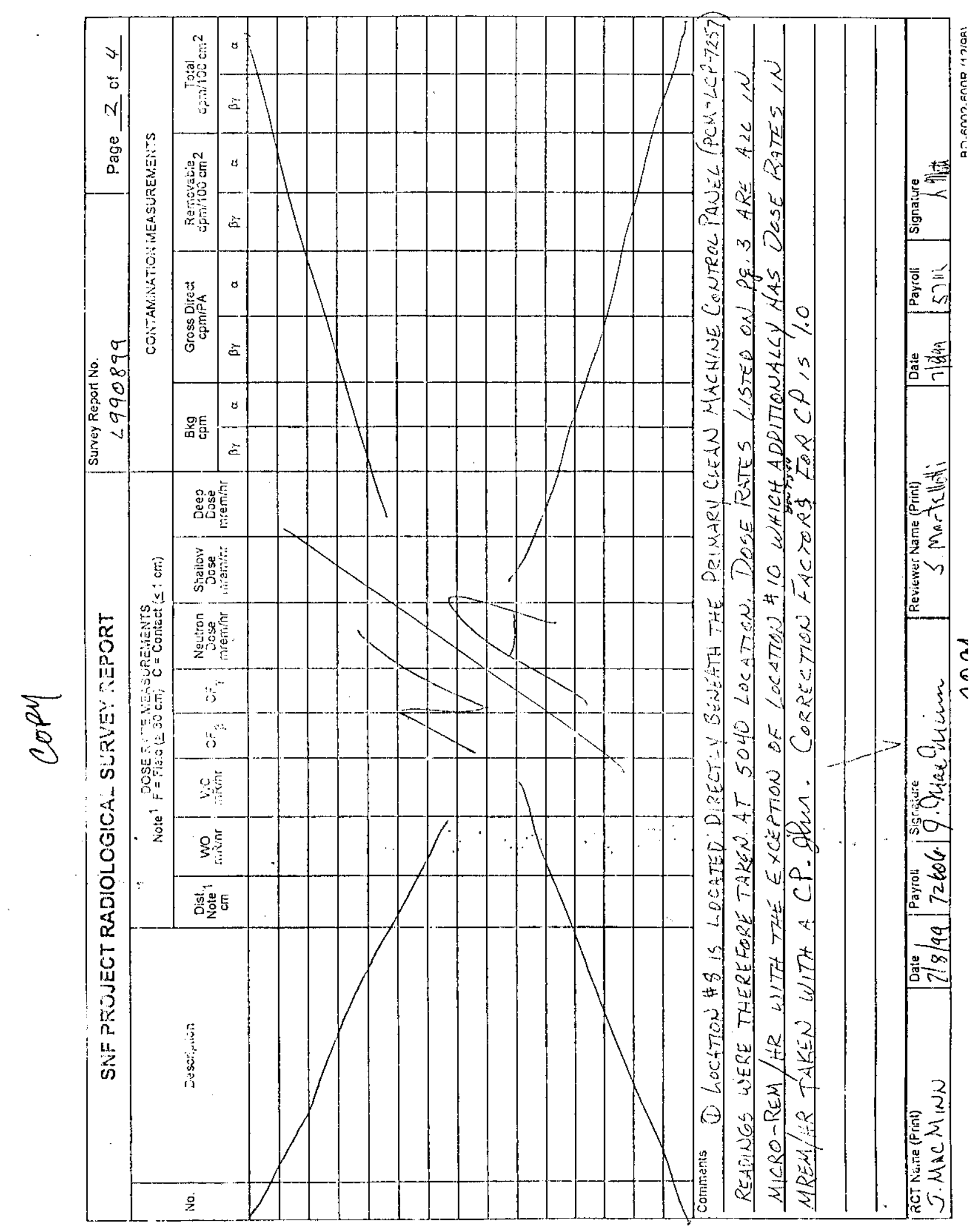


SNF-4977 REV 0

\begin{tabular}{|c|c|c|c|c|c|}
\hline \multicolumn{6}{|c|}{ STANDARDIZED DOSE RATE ${ }^{1}$ SURVEILLANCE } \\
\hline $\begin{array}{l}\text { Facility } \\
105 \mathrm{KW}\end{array}$ & \multicolumn{2}{|c|}{\begin{tabular}{l|l} 
Date & Basin Water Level \\
$7 / 8 / 99$ & 15 \\
\end{tabular}} & \multicolumn{2}{|c|}{$\begin{array}{l}\text { Survey Report No. } \\
2990899\end{array}$} & Page 3 of 4 \\
\hline \multicolumn{2}{|c|}{ Location No. } & \multicolumn{2}{|c|}{ Knee-Level Dose Rate ${ }^{2}$} & \multicolumn{2}{|c|}{ Chest-Level Dose Rate } \\
\hline \multicolumn{2}{|l|}{1} & \multicolumn{2}{|l|}{155} & \multicolumn{2}{|c|}{140} \\
\hline \multicolumn{2}{|l|}{2} & \multicolumn{2}{|l|}{190} & \multicolumn{2}{|c|}{190} \\
\hline \multicolumn{2}{|l|}{3} & \multicolumn{2}{|l|}{170} & \multicolumn{2}{|c|}{165} \\
\hline \multicolumn{2}{|l|}{4} & \multicolumn{2}{|l|}{110} & \multicolumn{2}{|c|}{95} \\
\hline \multicolumn{2}{|l|}{5} & \multicolumn{2}{|l|}{75} & \multicolumn{2}{|c|}{75} \\
\hline \multicolumn{2}{|l|}{6} & \multicolumn{2}{|l|}{115} & \multicolumn{2}{|c|}{100} \\
\hline \multicolumn{2}{|l|}{7} & \multicolumn{2}{|l|}{110} & \multicolumn{2}{|c|}{100} \\
\hline \multicolumn{2}{|r|}{ (1) } & \multicolumn{2}{|l|}{70} & \multicolumn{2}{|c|}{65} \\
\hline \multicolumn{2}{|l|}{9} & \multicolumn{2}{|l|}{130} & \multicolumn{2}{|c|}{110} \\
\hline \multicolumn{2}{|l|}{10} & $5 O C(0,6$ MREM)HA & $8)$ & 650 & $8 M R E M / A R\rangle$ \\
\hline 11 & & 14 & & & \\
\hline 12 & & 200 & & & 50 \\
\hline 13 & & 5 & & & \\
\hline 14 & & 140 & & & \\
\hline 15 & & 14 & & & \\
\hline 16 & & 11 & & & \\
\hline 17 & - & 25 & & & \\
\hline 18 & & 110 & & & 5 \\
\hline 19 & & 60 & & & \\
\hline 20 & & 220 & & & 50 \\
\hline 21 & & $1 / 5$ & & & 5 \\
\hline 22 & & 105 & & & 35 \\
\hline
\end{tabular}

1 All dose rates taken facing north.

${ }^{2.3}$ Readirigs taken with a $\mu R$ Meter, unless otherwise noted. 
SNF-4977 REV 0

\begin{tabular}{|l|l|l|}
\hline $105 \mathrm{KW}$ Standardized Dose Rate Locations & $\begin{array}{l}\text { Survey Report No } \\
\angle 990899\end{array}$ & Page 4 of -4 \\
\hline
\end{tabular}

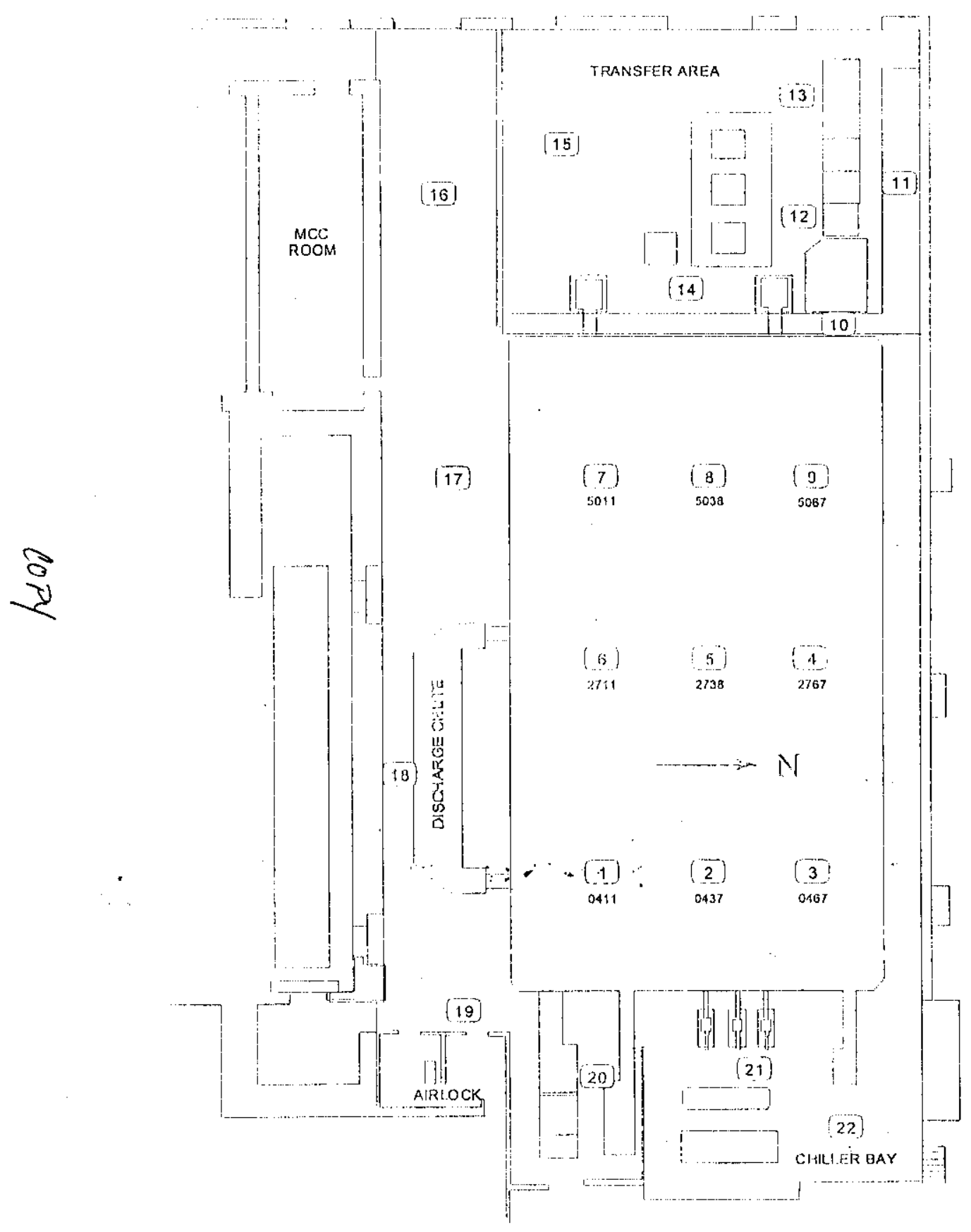


SNF-4977 REV 0

\section{APPENDIX F}

SPENT NUCLEAR FUEL PROJECT RADIOLOGICAL SURVEY REPORTS

K990552, K990556, K99059, AND K990564 
This page intentionally left blank. 


\section{APPENDIX F \\ SPENT NUCLEAR FUEL PROJECT \\ RADIOLOGICAL SURVEY REPORTS \\ K990552, K990556, K99059, AND K990564}

Personnel doses presented in Table 5-3 and computed in Appendix C required dose rates from radioactive material entrapped in integrated water treatment system ion exchange columns. The dose rates used are listed in Table 4-5. Those dose rates were based on measured data from Spent Nuclear Fuels Project radiological survey reports K990552, K990556, K99059, and K990564. The following pages contain reproductions of relevant pages from those reports. 
SNF-4977 REV 0

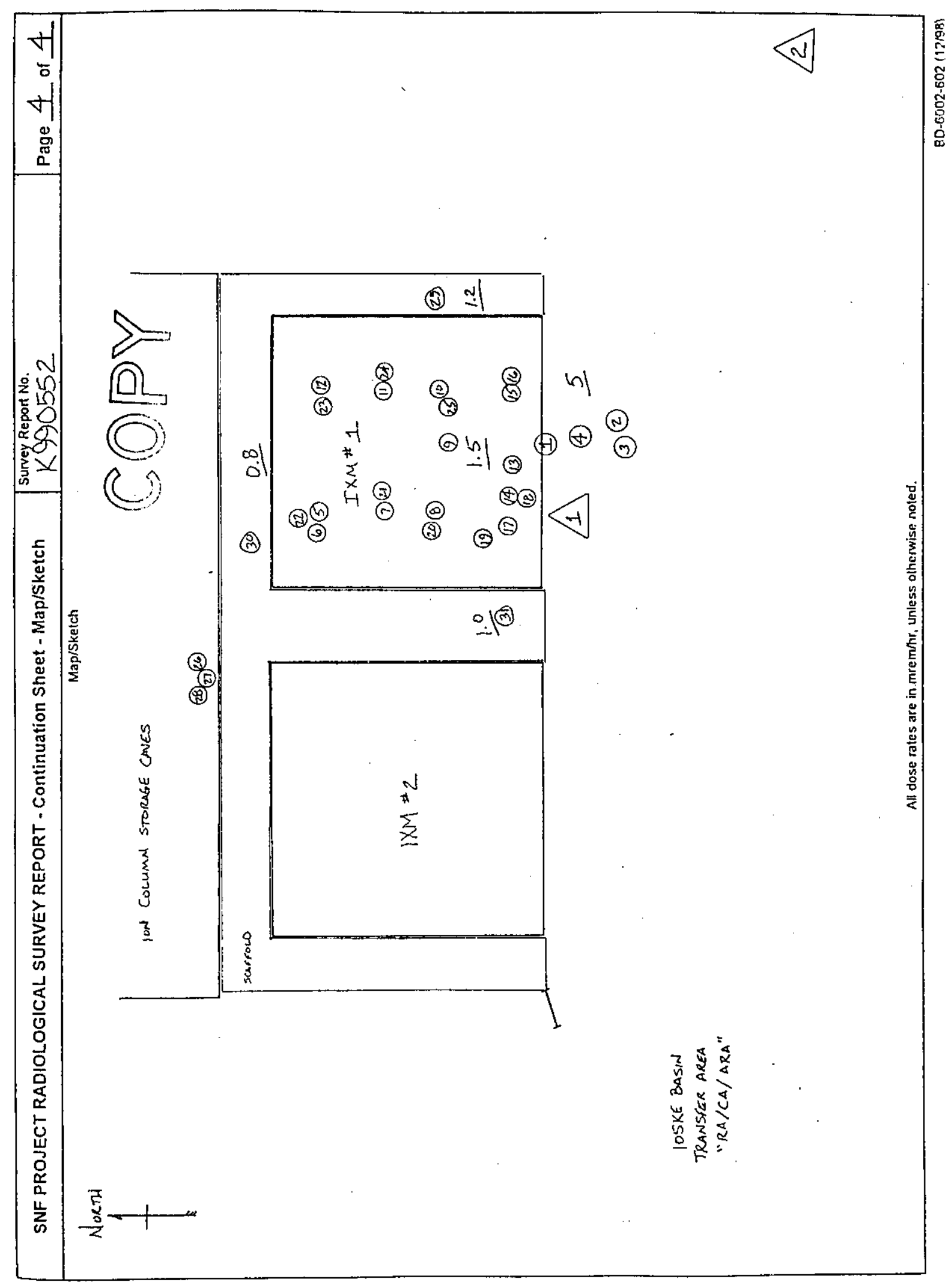




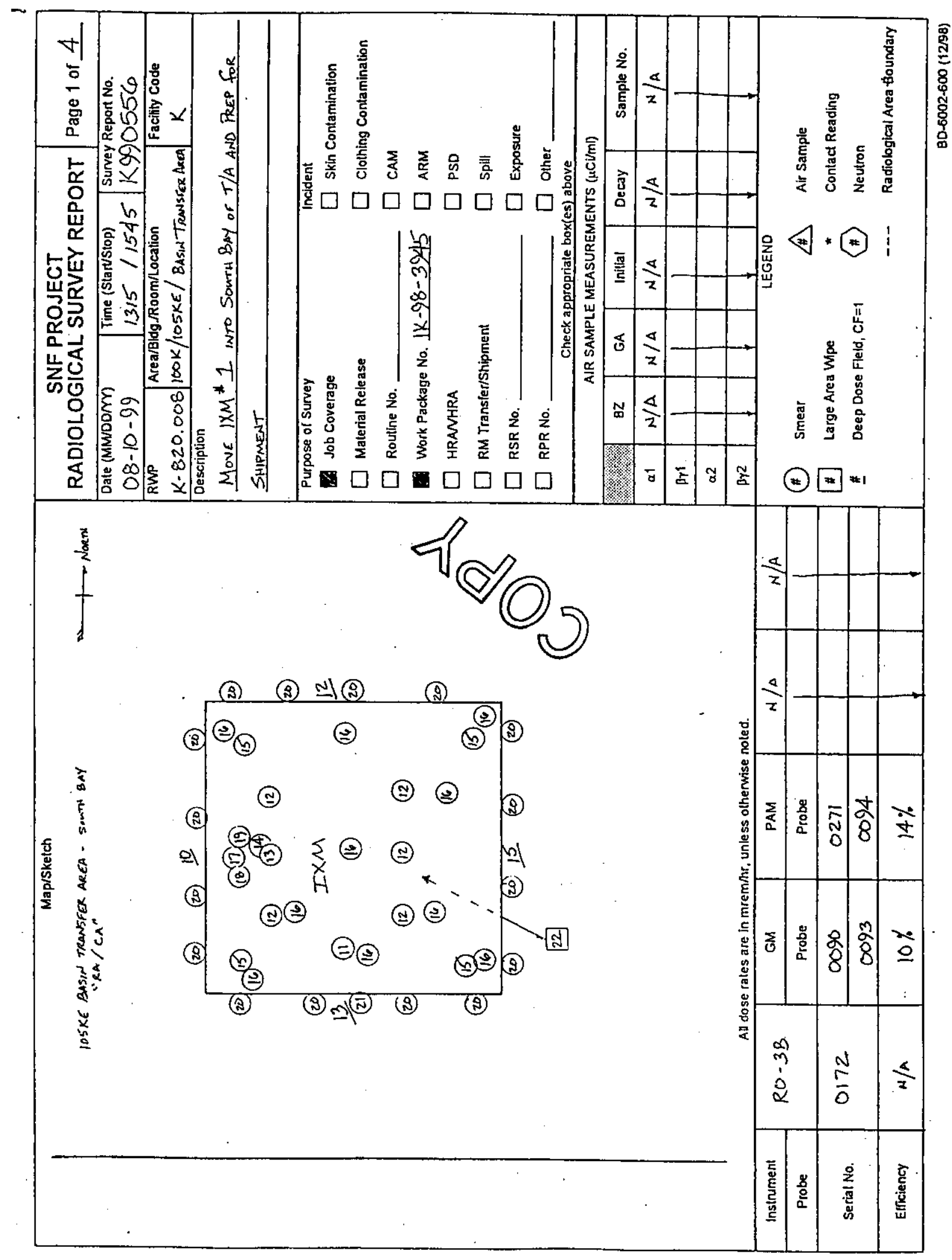




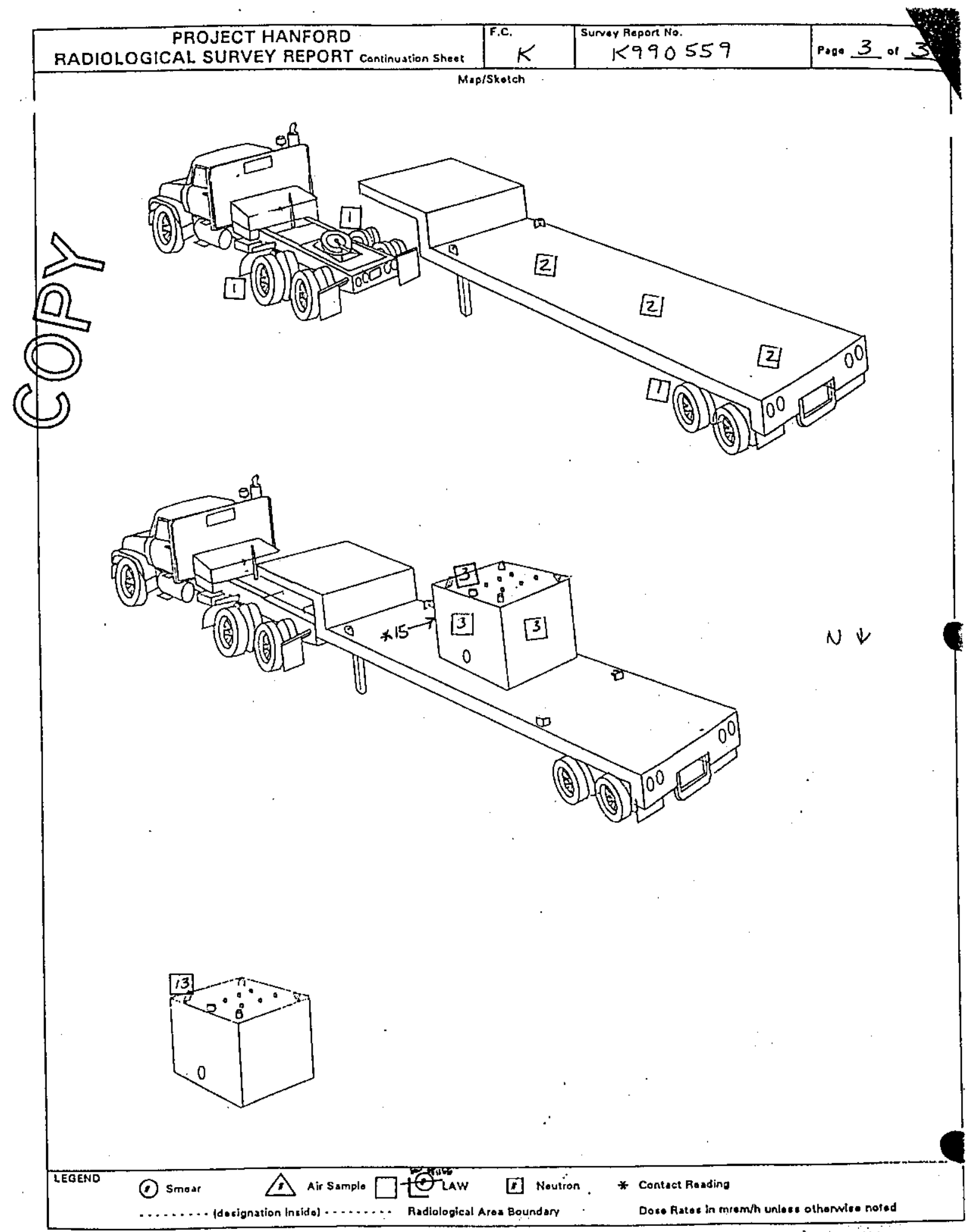




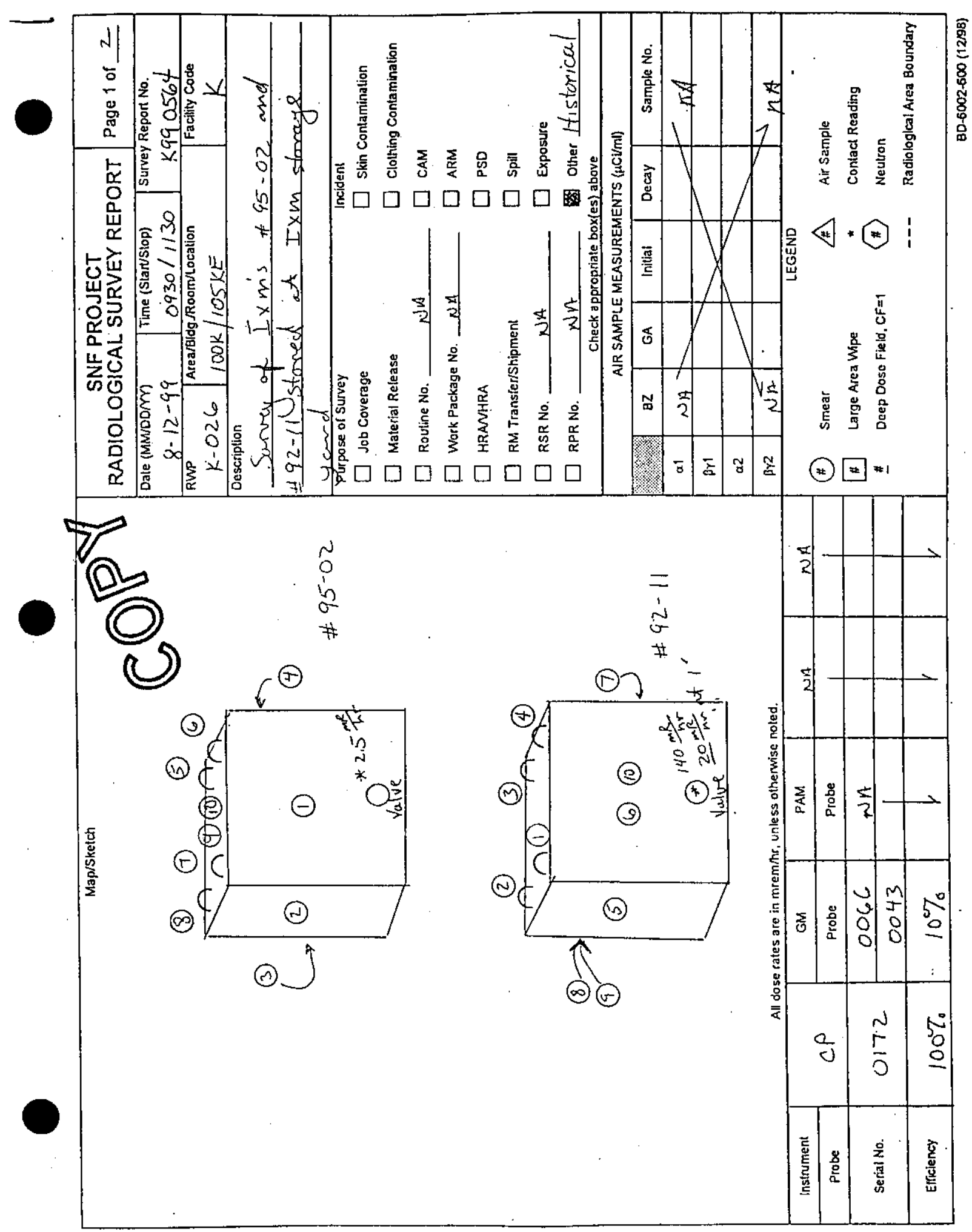


This page intentionally left blank. 
SNF-4977 REV 0

APPENDIX G

COMPUTATION OF DOSE RATES IN THE VICINITY OF A LOADED ION EXCHANGE MODULE AT THE K BASINS 
SNF-4977 REV 0

This page intentionally left blank. 


\section{APPENDIX G \\ COMPUTATION OF DOSE RATES IN THE VICINITY OF A LOADED ION EXCHANGE MODULE AT THE K BASINS}

Personnel doses presented in Table 5-3 and computed in Appendix C required dose rates from radioactive material entrapped in integrated water treatment system ion exchange columns (IXMs). The dose rates used are listed in Table G-1 and Table 4-5. Those dose rates were based on measured data from Spent Nuclear Fuel (SNF) Project radiological survey reports K990552, K990556, K99059, and K990564 (see Appendix F) and computations that are the subject of this appendix. The dose rates that were computed, rather than extracted directly from one of the four survey reports listed in Appendix F, are documented in Sections G.1, G.2, and G.3.

Table G-1. Dose Rates in Vicinity of a Loaded Integrated Water Treatment System Ion Exchange Module.

\begin{tabular}{|l|c|c|l|}
\hline \multicolumn{1}{|c|}{ Location } & $\begin{array}{c}\text { Distance (m) } \\
\text { from IXM }\end{array}$ & $\begin{array}{c}\text { Dose Rate } \\
(\mathrm{mrem} / \mathrm{h})\end{array}$ & \multicolumn{1}{|c|}{ Reference } \\
\hline Outlet side of IXM & 0.3 & 20 & $\begin{array}{l}\text { SNF Project Radiological Survey Report } \\
\text { K990564 }\end{array}$ \\
\cline { 2 - 4 } & 1.0 & 6.0 & Computed - see Section G.3. \\
\hline $\begin{array}{l}\text { Other three sides off IXM } \\
\text { (representative) }\end{array}$ & 0.3 & 10 & $\begin{array}{l}\text { Estimated from dose rates in SNF Project } \\
\text { Radiological Survey Reports K990552, } \\
\text { K990556 and K990559 (see Section G.1) }\end{array}$ \\
\cline { 2 - 5 } & 1.0 & 4.6 & Computed - see Section G-2 \\
\hline Above IXM & 0.3 & 1.5 & $\begin{array}{l}\text { SNF Project Radiological Survey Report } \\
\text { K990552 }\end{array}$ \\
\hline
\end{tabular}

IXM $=$ ion exchange module.

$\mathrm{SNF}=$ spent nuclear fuel project.

\section{G.1 Dose Rates One Foot from Sides of Ion Exchange Modules}

The $10 \mathrm{mrem} / \mathrm{h}$ dose rate listed in Table G-1 as the representative value $0.3 \mathrm{~m}(1 \mathrm{ft})$ from the sides of IXM (excluding the side with the outlet pipe) was based on an evaluation of dose rates in SNF Project survey reports K990552, K990556, and K990559. These data varied greatly, as shown in Table G-2, from 0.8 to $13 \mathrm{mrem} / \mathrm{h}$. The average of the nine data points in Table G-2 is $5.2 \mathrm{mrem} / \mathrm{h}$. . However, because of the variability in the data and the limited set of data, a value of $10 \mathrm{mrem} / \mathrm{h}$ was conservatively selected for use in the dose calculations (Bullock 1999). 
Table G-2. Measured Dose Rates (mrem/h) One Foot from the Side of Loaded Ion Exchange Modules.

\begin{tabular}{|c|c|c|c|}
\hline \multirow{2}{*}{ Side } & \multicolumn{3}{|c|}{ SNF Project Radiological Survey Report No. } \\
\cline { 2 - 4 } & K990552 & K990556 & K990559 \\
\hline 1 & 1.0 & 13.0 & 3.0 \\
\hline 2 & 0.8 & 12.0 & 3.0 \\
\hline 3 & 1.2 & 10.0 & 3.0 \\
\hline Average & 1.0 & 11.7 & 3.0 \\
\cline { 2 - 4 } & & 5.2 & \\
\hline
\end{tabular}

$\mathrm{SNF}=$ spent nuclear fuel.

\section{G.2 Dose Rates One Meter from Sides of Ion Exchange Modules}

The $4.6 \mathrm{mrem} / \mathrm{h}$ dose rate listed in Table G-1 as the value $1 \mathrm{~m}$ from the side of an IXM was based on the results from a previous ISOSHLD (WHC-SD-WM-UM-030) calculation of an IXM at the Cold Vacuum Drying Facility (SNF-2850). The IXMs to be used at the Cold Vacuum Drying Facility are identical in construction to those to be used in the integrated water treatment system. The dose rates from that calculation were scaled to give $10 \mathrm{mrem} / \mathrm{h}$ at $30 \mathrm{~cm}$ from the IXM. Scaling of the ISOSHLD results was done to get a $1-\mathrm{m}$ dose rate consistent with the $30-\mathrm{cm}$ dose rate of $10 \mathrm{mrem} / \mathrm{h}$ discussed in Section G.1. The raw and scaled ISOSHLD dose rates are shown in Table G-3. As noted in that table, the ISOSHLD run was not set up to compute the dose rate exactly $1 \mathrm{~m}$ from the IXM. So, the $1-\mathrm{m}$ dose rate was estimated by logarithmic interpolation of the scaled dose rates at $91 \mathrm{~cm}$ and $122 \mathrm{~cm}$.

\section{G.3 Dose Rates One Meter from Outlet Side of Ion Exchange Modules}

In estimating the dose rate $1 \mathrm{~m}$ from the outlet side of an IXM, it was assumed that the dose rates on that side were the sum of the dose rate from photons penetrating the concrete shielding around the ion exchange columns and photons streaming through the outlet pipe. The first component should be reasonably represented by the dose rates for the other sides of the IXM (i.e., the scaled data in Table G-3). It was further assumed that the photons from the outlet pipe can be represented as a point source in air and, thus dose rates from this source can be modeled as:

$$
\mathrm{D}(\mathrm{R})=\mathrm{C} /\left(\mathrm{r}_{0}+\mathrm{R}\right)^{2}
$$

where $D(R)$ is the dose rate $(\mathrm{mrem} / \mathrm{h})$ at a distance $\mathrm{R}(\mathrm{cm})$ from the side of the IXM at the outlet pipe opening, $C\left(\mathrm{mrem} \cdot \mathrm{cm}^{2} / \mathrm{h}\right)$ is a scaling factor and $\mathrm{r}_{0}$ is an effective distance $(\mathrm{cm})$ from the photon source to the edge of the IXM. The effective source to dose point distance is then $\mathrm{r}_{0}+\mathrm{R}$. The constants $\mathrm{C}$ and $\mathrm{r}_{0}$ were determined as described below. 
Table G-3. Raw and Scaled Dose Rates from ISOSHLD Calculation of an Ion Exchange Module.

\begin{tabular}{|c|c|c|}
\hline \multirow{2}{*}{$\begin{array}{c}\text { Distance from IXM } \\
(\mathrm{cm})\end{array}$} & \multicolumn{2}{|c|}{ Dose Rate (mrem/h) } \\
\cline { 2 - 3 } & ISOSHLD $^{\mathrm{a}}$ & Scaled $^{\mathbf{b}}$ \\
\hline 0 & 0.75 & 14.7 \\
\hline 30 & 0.51 & 10.0 \\
\hline 61 & 0.35 & 6.9 \\
\hline 91 & 0.26 & 5.0 \\
\hline 122 & 0.19 & 3.7 \\
\hline 152 & 0.15 & 2.9 \\
\hline 183 & 0.12 & 2.3 \\
\hline & & \\
\hline 100 & & $4.6^{\mathrm{c}}$ \\
\hline
\end{tabular}

${ }^{a}$ ISOSHLD results are from case CVDIXMA in SNF-2850.

${ }^{b}$ ISOSHLD results were scaled to give $10 \mathrm{mrem} / \mathrm{h}$ at a distance of $30 \mathrm{~cm}$.

${ }^{\mathrm{c}}$ The scaled dose rate of $4.6 \mathrm{mrem} / \mathrm{h}$ at $100 \mathrm{~cm}$ was obtained by logarithmic interpolation of the scaled dose rates at $91 \mathrm{~cm}$ and $122 \mathrm{~cm}$.

SNF Project radiological survey report K990564 shows the contact dose rate at the outlet pipe opening as $140 \mathrm{mrem} / \mathrm{h}$ and the $1-\mathrm{ft}(30 \mathrm{~cm})$ dose rate as $20 \mathrm{mrem} / \mathrm{h}$. From Table G-3, dose rates at IXM sides without a pipe penetration are $14.7 \mathrm{mrem} / \mathrm{h}$ at contact and $10 \mathrm{mrem} / \mathrm{h}$ at a distance of $30 \mathrm{~cm}$. Thus, the dose rate increases attributable to the outlet pipe penetration are $125.3 \mathrm{mrem} / \mathrm{h}$ at contact and $10 \mathrm{mrem} / \mathrm{h}$ at $30 \mathrm{~cm}$. From these two distance/dose rate pairs, values of $C$ and $r_{0}$ were determined by iteration to be $18,070 \mathrm{mrem} \cdot \mathrm{cm}^{2} / \mathrm{h}$ and $12.01 \mathrm{~cm}$, respectively. The dose rate $1 \mathrm{~m}$ from the outlet side of IXM from photon streaming through the outlet pipe was then computed to be $1.4 \mathrm{mrem} / \mathrm{h}$, and the total dose rate was computed to be $6.0 \mathrm{mrem} / \mathrm{h}$. This information is summarized in Table G-4. 
Table G-4. Dose Rates on the Outlet Side of a Loaded Ion Exchange Module.

\begin{tabular}{|c|c|c|c|}
\hline \multirow{2}{*}{$\begin{array}{c}\text { Distance from } \\
\text { IXM }(\mathrm{cm})\end{array}$} & \multicolumn{3}{|c|}{ Dose Rate (mrem/h) } \\
\cline { 2 - 4 } & $\begin{array}{c}\text { Without Outlet } \\
\text { Pipe }^{\mathrm{a}}\end{array}$ & $\begin{array}{c}\text { Due to Pipe } \\
\text { Penetration }\end{array}$ & Total \\
\hline 0 & 14.7 & $125.3^{\mathrm{b}}$ & $140.0^{\mathrm{d}}$ \\
\hline 30 & 10.0 & $10.0^{\mathrm{b}}$ & $20.0^{\mathrm{d}}$ \\
\hline 100 & 4.6 & $1.4^{\mathrm{c}}$ & $6.0^{\mathrm{e}}$ \\
\hline
\end{tabular}

Dose rates at side of IXM without the outlet pipe were taken from Table G-3.

${ }^{\mathrm{b}}$ Dose rates at $0 \mathrm{~cm}$ (contact) and $30 \mathrm{~cm}$ due to pipe penetration were computed as the difference between the total dose rates and the dose rates without the outlet pipe.

${ }^{\mathrm{c}}$ The dose rate at $100 \mathrm{~cm}$ due to the pipe penetration was computed using Equation G-1 with $\mathrm{C}=18,070 \mathrm{mrem} \cdot \mathrm{cm}^{2} / \mathrm{h}$ and $\mathrm{r}_{0}=12.01 \mathrm{~cm}$.

${ }^{d}$ Total dose rates at $0 \mathrm{~cm}$ (contact) and $30 \mathrm{~cm}$ were taken from SNF Project Survey Report K99064.

e The total dose rate at $100 \mathrm{~cm}$ was computed as the sum of the dose rate without an outlet pipe and the dose rate due to the pipe penetration.

IXM = ion exchange module.

$\mathrm{SNF}=$ spent nuclear fuel.

\section{REFERENCES}

Bullock, D. E., 1999, Ion Exchange Module Replacement Spreadsheets, August 26, Fluor Daniel Hanford Incorporated, Richland, Washington.

WHC-SD-WM-UM-030, 1995, ISO-PC Version 1.98 - User's Guide, Rev. 0, Westinghouse Hanford Company, Richland Washington.

SNF-2850, 1998, Shielding Analysis for the Cold vacuum Drying Project, Rev. 0, Fluor Daniel Hanford Incorporated, Richland, Washington. 
SNF-4977 REV 0

APPENDIX H

CHECKLIST FOR TECHNICAL PEER REVIEW 
SNF-4977 REV 0

This page intentionally left blank. 


\section{APPENDIX H}

\section{CHECKLIST FOR TECHNICAL PEER REVIEWS}

\section{CHECKLIST FOR TECHNICAL PEER REVIEW}

\section{Document Reviewed: SNF-4977}

Title: Integrated Worker Radiation Dose Assessment for the K Basins

Author: J. V. Nelson

Date: September 29, 1999

Scope of Review: Whole report except Appendices A, B, and C, which document spreadsheets I developed.

Yes No*NA

[x] [ ] [ ]**Previous reviews complete and cover analysis, up to scope of this review, with no gaps.

[x] [ ] [ ] Problem completely defined.

[ ] [ ] [x] Accident scenarios developed in a clear and logical manner.

[ $x$ ] [ ] [ ] Necessary assumptions explicitly stated and supported.

[ ] [ ] [x] Computer codes and data files documented.

[ $x$ ] [ ] [ ] Data used in calculations explicitly stated in document.

[ $x$ ] [ ] [ ] Data checked for consistency with original source information as applicable.

[ ] [ ] [x ] Mathematical derivations checked including dimensional consistency of results.

[ $x$ ] [ ] [ ] Models appropriate and used within range of validity or use outside of range of established validity justified.

[x ] [ ] [ ] Hand calculations checked for errors. Spreadsheet results should be treated exactly the same as hand calculations.

[ ] [ ] [x ] Software input correct and consistent with document reviewed.

[ ] [ ] [x ] Software output consistent with input and with results reported in document reviewed.

[ $x$ ] [ ] [ ] Limits/criteria/guidelines applied to analysis results are appropriate and referenced.

Limits/criteria/guidelines checked against references.

[ ] [ ] [ $x$ ] Safety margins consistent with good engineering practices.

[ $x$ ] [ ] [ ] Conclusions consistent with analytical results and applicable limits.

[ $x$ ] [ ] [ ] Results and conclusions address all points required in the problem statement.

[ $x$ ] [ ] [ ] Format consistent with applicable guides or other standards.

[ ] [ ] [x ]**Review calculations, comments, and/or notes are attached.

[x] [ ] [ ] Traceability

[ x] [ ] [ ] Document approved (for example, the reviewer affirms the technical accuracy of the document).

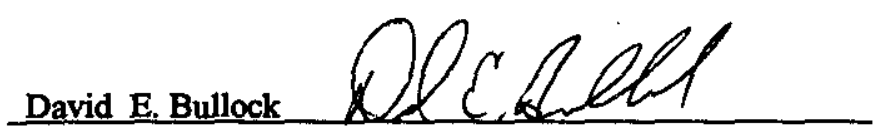

Reviewer (printed name and signature)
September 29, 1999

Date

* All "no" responses must be explained below or on an additional sheet.

** Any calculations, comments, or notes generated as part of this review should be signed, dated, and attached to this checklist. Such material should be labeled and recorded in such a manner as to be intelligible to a technically qualified third party. 
SNF-4977 REV 0

This page intentionally left blank. 


\section{DISTRIBUTION SHEET}

\begin{tabular}{|c|c|c|c|c|c|}
\hline \multirow{2}{*}{$\begin{array}{l}\text { To } \\
\text { Distribution }\end{array}$} & \multirow{2}{*}{\multicolumn{3}{|c|}{$\begin{array}{l}\text { From } \\
\text { Nuclear Safety }\end{array}$}} & \multicolumn{2}{|l|}{ Page 1 of 1} \\
\hline & & & & \multicolumn{2}{|l|}{ Date } \\
\hline \multirow{3}{*}{\multicolumn{4}{|c|}{$\begin{array}{l}\text { Project Title/Work Order } \\
\text { SNF-4977, Rev. } 0 \\
\text { Integrated Worker Radiation Dose Assessment for the K Basins }\end{array}$}} & \multicolumn{2}{|c|}{ EDT No. 626894} \\
\hline & & & & \multirow{2}{*}{\multicolumn{2}{|c|}{ ECN No. N/A }} \\
\hline & & & & & \\
\hline Name & MSIN & $\begin{array}{c}\text { Text } \\
\text { With All } \\
\text { Attach. }\end{array}$ & Text Only & $\begin{array}{l}\text { Attach./ } \\
\text { Appendix } \\
\text { Only }\end{array}$ & $\begin{array}{c}\text { EDT/ECN } \\
\text { Only }\end{array}$ \\
\hline D. E. Bullock & $X 3-76$ & $\mathbf{X}$ & & & \\
\hline J. D. Carlson & R3-26 & $\mathbf{X}$ & & & \\
\hline R. D. Crowe & R3-26 & $\mathrm{X}$ & & & \\
\hline G. M. Davis & $X 3-80$ & $\mathbf{X}$ & & & \\
\hline R. L. Garrett & R3-26 & $X$ & & & \\
\hline K. D. Gibson & R3-26 & $X$ & & & \\
\hline S. B. Harrington & R3-26 & $\mathbf{X}$ & & & \\
\hline S. F. Kessler & R3-26 & $\mathbf{X}$ & & & \\
\hline J. E. Kurtz & $X 3-68$ & $\mathbf{X}$ & & & \\
\hline J. V. Nelson & R3-26 & $\mathbf{X}$ & & & \\
\hline S. H. Peck & R3-26 & $X$ & & & \\
\hline J. D. Mathews & $X 3-65$ & $\mathbf{X}$ & & & \\
\hline R. H. Webb & R3-26 & $\mathbf{X}$ & & & \\
\hline K Basins Project Files & $X 3-85$ & $\mathbf{X}$ & & & \\
\hline SNF Project Files & R3-11 & $\mathbf{X}$ & & & \\
\hline
\end{tabular}

